\title{
42. SYNTHESIS OF TERRIGENOUS ACCUMULATION RATES AND BIOSTRATIGRAPHIC STUDIES AT SITES IN THE NORTHWESTERN PACIFIC OCEAN, WITH COMPARISONS TO ADJACENT REGIONS OF THE PACIFIC GYRE ${ }^{1}$
}

\author{
Frank R. Rack, ${ }^{2}$ Thomas R. Janecek, ${ }^{3}$ Elisabetta Erba, ${ }^{4}$ Juliane Fenner, ${ }^{5}$ and Jeffrey S. Gee ${ }^{6}$
}

\begin{abstract}
This paper presents the integrated results of quantitative sedimentologic and biostratigraphic studies at Sites 871,872 , and 873 in the Marshall Islands, Hole 880A on Takuyo-Daisan Guyot, and Hole 810C on Shatsky Rise for the late Pliocene to Holocene. Published results from studies of terrigenous mineral (eolian) accumulation at additional Ocean Drilling Program, Deep Sea Drilling Project, and piston core sites located around or within the boundaries of the (Northern Hemisphere) Pacific Subtropical Gyre are used to provide additional regional comparisons among high-quality, high-resolution eolian records from the Pacific Basin.

Two time intervals have been selected for these regional comparisons. The first interval selected is from 3 million years ago (Ma) to the present, which allows for comparisons to be made among several sites which have relatively low temporal resolution records. The second interval is from $600 \mathrm{ka}$ to the present, which allows for comparisons to be made among the small number of high-quality, high-resolution, proxy records from sites in the northwest and equatorial Pacific Ocean. Additional discussions will focus on the potential for correlating several marine records of terrigenous dust accumulation at sites located downwind from Asia beneath the Pacific Subtropical Gyre with the continental climate record preserved in alternating loess and soil deposits of Central China.
\end{abstract}

\section{INTRODUCTION}

The goal of this paper is to combine the results of recent sedimentologic and biostratigraphic studies of cores collected during Ocean Drilling Program (ODP) Leg 144. We will discuss the sedimentologic results from two guyots in the Marshall Islands (Lo-En and Wodejebato guyots; Holes 871 A and 873B; Rack, Bohrmann, and Hobbs, this volume) and from Takuyo-Daisan Guyot (Hole 880A; Rack, Lawyer, and Gee, this volume), and the results from quantitative studies of nannofossil biostratigraphy (Erba, this volume) and studies of siliceous microfossils (Fenner, this volume) from Quaternary sediments at these same sites. The sedimentologic and biostratigraphic data will be used to discuss the timing of terrigenous mineral fluxes to the northwest and southern to southwest regions of the (Northern Hemisphere) Pacific Subtropical Gyre, and the relationships between mineral fluxes, nannofloral assemblage shifts, and paleoclimatic changes.

Sediment mass accumulation rates (MAR) of different sedimentary components have been calculated at each of these sites to allow for comparisons across a wide geographic region, primarily using sites located at intermediate water depths. The calculated flux data for Hole 880A are given in Appendix A of this paper; the flux data for Holes $871 \mathrm{~A}$ and $873 \mathrm{~B}$ are slightly modified from Rack, Bohrmann, and Hobbs (this volume). The combined results from these Leg 144 sites are compared with the published results from sedimentologic, magnetic, and biostratigraphic studies at Hole $810 \mathrm{C}$ (Premoli Silva et al., 1993; Rack et al., 1993; Sager et al., 1993) and with unpublished mineral flux data from this same hole on Shatsky Rise (see Appendix B; Rack and Janecek, unpubl. data). The results of these laboratory

${ }^{1}$ Haggerty, J.A., Premoli Silva, I., Rack, F., and McNutt, M.K. (Eds.), 1995. Proc. $O D P$, Sci. Results, 144: College Station, TX (Ocean Drilling Program).

${ }^{2}$ Ocean Mapping Group, Department of Geodesy and Geomatics Engineering, University of New Brunswick, Fredericton, New Brunswick E3B 5A3, Canada.

${ }^{3}$ Antarctic Research Facility, Department of Geology, 108 Carraway Building, Florida State University, Tallahassee, FL 32306-3026, U.S.A.

${ }^{4}$ Dipartimento di Scienze della Terra, Università di Milano, Via L. Mangiagalli 34. I-20133 Milano, Italy.

${ }^{5}$ Bundesanstalt für Geowissenschaften und Rohstoffe, Stilleweg 2, D-30655 Hannover, Federal Republic of Germany.

${ }^{6}$ Lamont-Doherty Earth Observatory, Columbia University, Palisades, NY 10964. U.S.A. analyses and the age model derived from an integrated magnetostratigraphy and biostratigraphy for Hole 810C (Premoli Silva et al., 1993; Sager et al., 1993) have been used to calculate MARs for sedimentary components for the time interval from late Pliocene to present (see Appendix C).

Published results from mineral (eolian) studies in the northwestern and equatorial to tropical Pacific Ocean have been utilized to produce summary figures of the weight percentages and mass accumulation rates of individual sedimentary components (for site locations, see Table 1 and Fig. 1) to allow for effective regional comparisons among sites. These summary figures show the temporal resolution of data from previous eolian studies around the Pacific Subtropical Gyre for the late Pliocene to Quaternary. The figures can be used to evaluate potential differences among the various age models for these records, and can provide a glimpse of the present state of our understanding of these proxy records, which are used to identify changes in atmospheric circulation and source region aridity around the Pacific Basin (see review by Rea, 1994).

Two discrete time intervals ( $0-3 \mathrm{Ma}$ and $0-600 \mathrm{ka})$ are presented in this paper. These two intervals were selected to assess our current understanding of late Pliocene to Quaternary terrigenous mineral (eolian) records from two widely separated regions of the Pacific Subtropical Gyre: one in the equatorial to tropical North Pacific, and one in the northwest Pacific Ocean.

In the first part of this synthesis, two transects of sites in the tropical North Pacific Ocean are shown: one transect in the western equatorial Pacific (Hole 803D, Krissek and Janecek, 1993; Holes 871A, 872A, and 873B; Rack, Bohrmann, and Hobbs, this volume), and one transect in the eastern equatorial Pacific (Holes 848B, 849B, 852B, and 853B; Hovan, 1995). These two transects of sites are compared for the interval 0-3 Ma. In addition, these low-resolution records are compared with the high-resolution records from piston Core RC11-210 (Chuey et al., 1987; Rea et al., 1991), located at a site between these two transects in the central equatorial Pacific Ocean.

The second part of this synthesis presents a discussion of terrigenous records from the Northwest Pacific Ocean. Two new records are presented: one from Hole 880A (Rack, Lawyer and Gee, this volume; Appendix A) and one from Hole 810C (Rack et al., 1993; Appendixes B and C). The sediment record from Hole $880 \mathrm{~A}$ is considered to be a hemipelagic record, with significant quantities of volcaniclastic material and possibly terrigenous material transported 
Table 1. Selected sites where eolian studies have been conducted in the Pacific Ocean.

\begin{tabular}{|c|c|c|c|c|c|}
\hline $\begin{array}{c}\text { Site } \\
\text { (Hole) }\end{array}$ & Latitude & Longitude & $\begin{array}{l}\text { Water } \\
\text { depth } \\
\text { (mbsl) }\end{array}$ & Reference to data & $\begin{array}{c}\text { Site ID No. } \\
\text { (Fig. I) }\end{array}$ \\
\hline KK $75-02$ & $38^{\circ} 37.00^{\prime} \mathrm{N}$ & $179^{\circ} 20.00^{\prime} \mathrm{E}$ & 5475 & Janecek (1983) & 1 \\
\hline $\mathrm{V} 21-146$ & $37^{\circ} 41.00^{\prime} \mathrm{N}$ & $163^{\circ} 02.00^{\prime} \mathrm{E}$ & 3968 & Hovan et al. $(1989,1991)$ & 2 \\
\hline 310 & $36^{\circ} 52.00^{\prime} \mathrm{N}$ & $176^{\circ} 54,00^{\prime} \mathrm{E}$ & 2525 & Rea and Janecek (1982), Janecek (1983) & 3 \\
\hline $880 \mathrm{~A}$ & $34^{\circ} 12.53^{\prime} \mathrm{N}$ & $144^{\circ} 18.74^{\prime} \mathrm{E}$ & 1525 & Rack et al. (this volume: this paper) & $4^{*}$ \\
\hline 578 & $33^{\circ} 55.56^{\prime} \mathrm{N}$ & $151^{\circ} 37.74^{\prime} \mathrm{E}$ & 6010 & Janecek (1985) & $5^{\text {k* }}$ \\
\hline $810 \mathrm{C}$ & $32^{\circ} 25.40^{\prime} \mathrm{N}$ & $157^{\circ} 50.44^{\prime} \mathrm{E}$ & 2623 & Rack et al. (1993) & 6 \\
\hline 576 & $32^{\circ} 21.40^{\prime} \mathrm{N}$ & $164^{\circ} 16.50^{\prime} \mathrm{E}$ & 6200 & Janecek (1985), Leinen (1985) & 7 \\
\hline 463 & $21^{\circ} 21.00^{\prime} \mathrm{N}$ & $174^{\circ} 40.00^{\prime} \mathrm{E}$ & 2525 & Rea and Janecek (1981, 1982) & 8 \\
\hline $873 \mathrm{~B}$ & $11^{\circ} 53.84^{\prime} \mathrm{N}$ & $164^{\circ} 55.23^{\prime} \mathrm{E}$ & 1334 & Rack et al. (this volume) & 9 \\
\hline $872 \mathrm{~A}$ & $10^{\circ} 05.85^{\prime} \mathrm{N}$ & $162^{\circ} 51.96^{\prime} \mathrm{E}$ & 1084 & Rack et al. (this volume) & 10 \\
\hline 871A & $5^{\circ} 33.43^{\prime} \mathrm{N}$ & $172^{\circ} 20.66^{\prime} \mathrm{E}$ & 1255 & Rack et al. (this volume) & 11 \\
\hline $803 \mathrm{D}$ & $2^{\circ} 25.98^{\prime} \mathrm{N}$ & $160^{\circ} 32.46^{\prime} \mathrm{E}$ & 3412 & Krissek and Janecek (1993) & 12 \\
\hline LL44-GPC3 & $30^{\circ} 20.00^{\prime} \mathrm{N}$ & $157^{\circ} 49.00^{\prime} \mathrm{W}$ & 5705 & Leinen and Heath (1981), Janecek and Rea (1983) & 13 \\
\hline $853 \mathrm{~B}$ & $7^{\circ} 12.66^{\prime} \mathrm{N}$ & $109^{\circ} 45.08^{\prime} \mathrm{W}$ & 3716 & Hovan (in press) & 14 \\
\hline $852 \mathrm{~B}$ & $5^{\circ} 17.57^{\prime} \mathrm{N}$ & $110^{\circ} 4.58^{\prime} \mathrm{W}$ & 3860 & Hovan (in press) & 15 \\
\hline $503 \mathrm{~B}$ & $4^{\circ} 03.02^{\prime} \mathrm{N}$ & $95^{\circ} 38.32^{\prime} \mathrm{W}$ & 3672 & Rea and Janecek (1982), Rea et al. (1986) & 16 \\
\hline $\mathrm{RC} 11-210$ & $1^{\circ} 49.00^{\prime} \mathrm{N}$ & $140^{\circ} 03.00^{\prime} \mathrm{W}$ & 4420 & Chuey et al. (1987), Rea et al. (1991) & 17 \\
\hline $849 B$ & $0^{\circ} 10.98^{\prime} \mathrm{N}$ & $110^{\circ} 31.18^{\prime} \mathrm{W}$ & 3840 & Hovan (in press) & 18 \\
\hline $848 \mathrm{~B}$ & $2^{\circ} 59.63$ 'S & $110^{\circ} 28.79 \mathrm{~W}$ & 3856 & Hovan (in press) & 19 \\
\hline
\end{tabular}

Notes: Single asterisk $\left(^{*}\right)=$ Hole $880 \mathrm{~A}$ is considered a hemipelagic site, which contains significant quantities of continentally derived and volcanic material. Caution should be exercised when comparing the results obtained from this hole with other sites on this list. Double asterisks (**) $=$ Site 578 is also considered to be a hemipelagic site (see Rea, Basov, Janecek, Palmer-Julson, et al., 1993). Site identification numbers are provided to help the reader locate these sites in Figure 1, mbsl = meters below sea level.

as runoff from Japan and/or China; therefore, we will not discuss this site in the context of eolian transport of grains.

The record of terrigenous mineral accumulation at Hole $810 \mathrm{C}$ on southern Shatsky Rise is combined with prior results from this hole (Natland, 1993; Polgreen et al., 1993; Premoli Silva et al., 1993; Rack et al., 1993; Sager et al., 1993), which are compared with the results of published eolian studies from piston Cores V21-146 (Hovan et al., 1989, 1991; northern Shatsky Rise) and KK75-02 (Janecek, 1983; Janecek and Rea, 1984, 1985; north central Pacific Ocean). These marine records are then compared with the continental record of climate represented by fluctuations in magnetic susceptibility measurements from the Xifeng I loess site in Central China (Kukla et al., 1988, 1990; Liu et al., 1988a, 1988b).

\section{BACKGROUND AND PREVIOUS WORK}

During the past 20 years a large number of eolian studies have been conducted, using marine sediment samples to examine the linkages between atmospheric and oceanographic processes over millions of years, and at shorter time scales (Rea, 1994). Studies in the north Pacific Ocean have emphasized the importance of understanding changes in the relative intensity and positions of the Northern Hemisphere westerlies and equatorial trade wind belts, which control the grain size distribution of transported mineral dust from continental source regions, and the role of continental aridity in determining the magnitude of the terrigenous dust flux to the Pacific Ocean.

The complex proxy environmental signals provided by fluctuations in eolian mass accumulation rates and changes in mineral grain size are linked to a wide array of processes, some better understood than others, including: (1) seasonal or interannual variability of eolian and atmospheric transport processes (Arimoto, et al., 1985; Betzer et al., 1988; Blank et al., 1985; Duce et al., 1980, 1983, 1991; Merrill et al., 1989; Uematsu et al., 1983, 1985; among others); (2) climatic or orbital (tens to hundreds of thousands of years) fluctuations in the geographic position and intensity of the mid- and low-latitude wind belts (westerly and easterly wind systems, respectively) and the Intertropical Convergence Zone (Hovan, 1995; Janecek and Rea, 1983. 1984, 1985; Rea, 1990, 1994; Rea et al., 1985; Wyrtki, 1974; among others); (3) temporal changes in the aridity or seasonality of continental source regions where eolian dust originates (Leinen, 1989; Prospero, 1981; Phillips et al., 1993; Pye and Zhou, 1989; Rea and Leinen, 1988; Windom, 1976; Zhang et al., 1994; among others); and (4) temporal fluctuation in the atmospheric transport of volcanic particles to these regions (Furuta, et al., 1986; Kamata, 1989; Kennett and Thunell, 1975; Kennett et al., 1977; Machida and Arai, 1983, 1988; Natland, 1993).

Some of the initial eolian studies conducted on Deep Sea Drilling Project (DSDP) cores were focused on the aseismic rises of the North Pacific Ocean (Hess Rise, Shatsky Rise, and the Mid-Pacific Mountains), which are located above the nepheloid layer, south of the latitude of ice-rafted sedimentation during both glacial and interglacial times, and which lie far from the continental sources of hemipelagic deposition in the Pacific (Rea and Janecek, 1981). Marine researchers have explained Cenozoic fluctuations in mineral mass accumulation rates at these sites as having resulted from changes in the aridity of the source regions of the mineral dust (Janecek and Rea, 1983, 1984; Leinen and Heath, 1981; Rea and Janecek, 1981, 1982; also see Rea, 1994), and they have explained changes in the median grain size of the mineral particles as having resulted from changes in the energy or strength of the transporting medium (atmospheric winds).

From the late Miocene to the Quaternary, there has been a significant increase in the accumulation of eolian (inorganic crystalline) material at several mid-Pacific sites (e.g., DSDP Sites 310 and 463, and giant piston Core LL44-GPC3; Leinen and Heath, 1981; Rea and Janecek, 1981, 1982; Janecek and Rea, 1983), which has been explained by a combination of factors, including the following: tectonic motions that have transported sites through or into the influence of various wind belts, Northern Hemisphere climatic deterioration and the subsequent intensification of atmospheric circulation as continental ice-sheets expanded, and periodic pulses of global or regional volcanism (Kennett and Thunnell, 1975; Kennett et al., 1977; Rea and Scheidegger, 1979).

This synthesis attempts to bring together the existing data from a number of sites around the North Pacific Ocean where late Pliocene to Quaternary mineral dust (eolian) studies have been undertaken. Where possible, the published data from these studies have been supplemented to construct an internally consistent set of figures with which to compare similar time intervals at various site locations around the Pacific Subtropical Gyre.

\section{METHODS}

\section{Chemical Analyses and Mineral Extractions}

Samples from Holes 871A, 873B, 880A, and 810C (Fig. 1) were freeze-dried, weighed, and used for laboratory chemical analyses to 


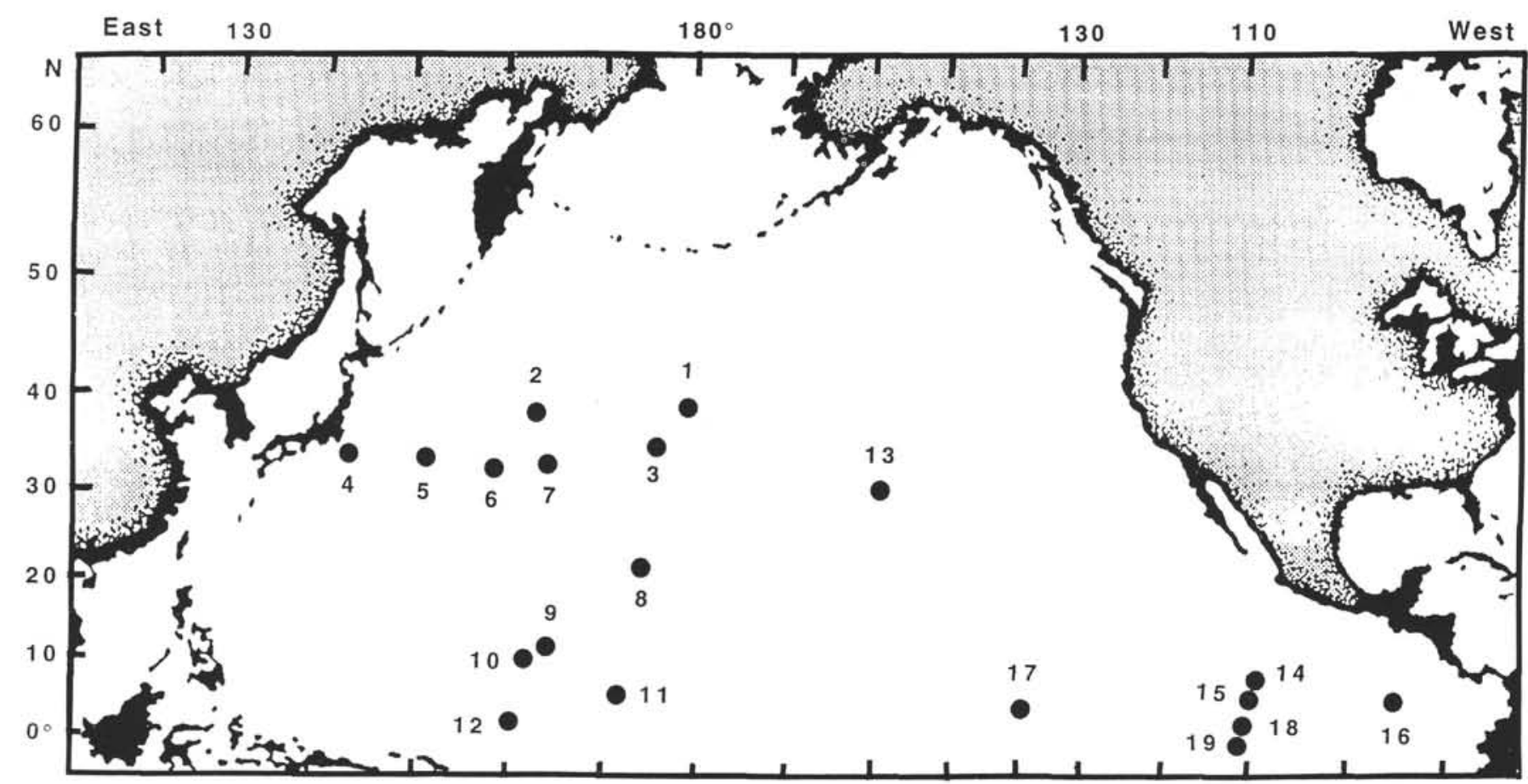

Figure 1. Location map showing selected sites used for eolian studies in the Pacific Ocean. The numbers on this map correspond to the appropriate sites listed in Table 1.

determine the weight percentages of inorganic carbon and calcium carbonate, and the weight percentage of the fine-grained lithogenic fraction $(<63-\mu \mathrm{m}$-sized mineral grains) of the bulk sediment (see discussion of methods and data contained in Rack et al., data reports, this volume; and Rack et al., 1993).

The inorganic carbon content of each sample was determined using a Coulometrics carbon dioxide coulometer. Calibration was performed using pure calcium carbonate as a standard. The weight percentage of carbonate was calculated from the inorganic carbon (IC) content, assuming that all carbonate was in the form of calcite: weight percentage of $\mathrm{CaCO}_{3}=\% \mathrm{IC} \times 8.332$.

Following the determination of inorganic carbon, a split of each sample was weighed and then processed according to a lithogenic extraction procedure, as described by Rea and Janecek (1981) and Clemens and Prell (1990). The lithogenic component of the bulk sediment (including contributions from both terrigenous and volcanic sources) was isolated by a series of selective extractions to remove calcium carbonate, opaline silica, Fe and Mn oxides, hydroxides and zeolites. The material passing through a $<63-\mu \mathrm{m}$ sieve after the completion of the extraction procedure was weighed to determine the weight percentage of the fine-grained terrigenous or mineral fraction $(<63 \mu \mathrm{m})$ of the total sample.

Throughout this paper, the extracted silt + clay-sized inorganic mineral fraction of the bulk samples (including both lithogenic and volcanic grains $<63 \mu \mathrm{m}$ in size) are referred to as either the "finegrained terrigenous" or "fine-grained lithogenic" fraction of the bulk sediment; these designations do not necessarily indicate an eolian transport mechanism for this material. In general, the fine-grained lithogenic fraction of these samples is dominated by clays, finegrained quartz, and grains of probable volcanic origin.

\section{Sediment Mass Accumulation Rate Calculations}

Dry bulk density values were determined for each sample at Holes $871 \mathrm{~A}, 873 \mathrm{~B}$, and $810 \mathrm{C}$ using either laboratory data, or regressions between laboratory measurements of dry bulk density and the wet-bulk density data collected by the GRAPE (gamma-ray attenu- ation porosity evaluator) at each site (see Rack et al., 1993; Rack, Bohrmann, and Hobbs, this volume).

Because of the scarcity of physical properties measurements at Hole $880 \mathrm{~A}$, estimates of dry bulk density were determined using a regression derived at Hole $810 \mathrm{C}$ between laboratory dry bulk densities and GRAPE bulk density values. The bulk sediment recovered in Hole $810 \mathrm{C}$ is lithologically similar to that recovered in Hole $880 \mathrm{~A}$ (calcareous ooze), although Hole $810 \mathrm{C}$ has significantly less coarsegrained material (lithogenic and volcanic grains) than is found at Hole $880 \mathrm{~A}$. The abundance of coarse-grained material at Hole $880 \mathrm{~A}$ leads us to classify it as a hemipelagic site that has been influenced by late Neogene volcanism and by possible surface runoff from Japan and/or China. A comparison of the six laboratory determinations of dry bulk density at Hole $880 \mathrm{~A}$ and predicted dry density values, which were determined from the GRAPE bulk density record at Hole 880A and the regression equation from Hole $810 \mathrm{C}$, indicate that the predicted values are about $10 \%-20 \%$ higher than the laboratory values. Calculated accumulation values are slightly high because of this error, but errors in linear sedimentation rate determinations are likely to be of equal or greater magnitude.

The product of the linear sedimentation rate $(\mathrm{LSR}=\mathrm{cm} / \mathrm{k} . \mathrm{y}$.) and the dry bulk density $\left(\mathrm{DBD}=\mathrm{g} / \mathrm{cm}^{3}\right)$ equals the sediment mass accumulation rate $\left(\mathrm{MAR}=\mathrm{g}\left[\mathrm{cm}^{2} \times \mathrm{k} \cdot \mathrm{y} .\right]^{-1}\right)$. The MAR is multiplied by the percentage of each sedimentary component to give MARs for the carbonate (CAR), noncarbonate (NCAR), and terrigenous (TMAR) components of the total flux at each site. The values of terrigenous mass accumulation rate (TMAR) are presented in units of $\mathrm{mg}\left(\mathrm{cm}^{2} \times \mathrm{k} . \mathrm{y} \text {. }\right)^{-1}$.

When possible, the weight percentage and accumulation of the "unknown" portion of the bulk sediment has been estimated. This has been accomplished by assuming that the total sample equals $100 \%$, and then subtracting the weight percentages of various "known" components to determine what is unknown. This calculation is presented to show the possible importance of various components of the total sedimentary flux (coarse-grained lithogenic grains, biogenic opal, Fe and Mn oxides, hydroxides and zeolites, and organic carbon), which are often not accounted for in the available chemical data provided by published studies. 


\section{Quantitative Biostratigraphic Studies}

Erba (this volume) presents quantitative studies of calcareous nannoflora from Sites $871,872,873$ and 880 using the informal morphometric taxonomic concepts described by Rio (1982), Rio et al. (1990), and Raffi et al. (1993) within the genus Gephyrocapsa. The Gephyrocapsa group shows very high abundances with respect to the other groups of small-sized coccoliths (non-Gephyrocapsa species of nannoflora) of Pleistocene age. The identification of Gephyrocapsa events has been shown to be highly useful for subdividing Pliocene to Quaternary age sequences for high-resolution studies of biostratigraphy and paleoceanography (Raffi et al., 1993; Wei, 1993).

Several recent studies have highlighted the use of these morphometric taxonomic concepts in nannoflora biostratigraphy, which can be integrated with correlations to oxygen isotope records and astronomical calibration (see studies by Castradori, 1993; Wei, 1993; Raffi and Flores, 1995; among others).

For the Leg 144 sites, a polarizing light microscope was used to count at least 500 specimens in a smear slide made from each sample (Erba, this volume). The percentages of single classes within the genus Gephyrocapsa were calculated from the original counts of total nannofloras. At Hole 810C, Premoli Silva et al. (1993) have conducted a similar, although semi-quantitative biostratigraphic study, using similar taxonomic methods. These data are used to provide age models for use in the calculation of sedimentary fluxes at Sites 871, 873,880 and 810 .

The ages that have been assigned to the biostratigraphic datums used in this study (see Table 2) are from a recent late Neogene synthesis of sites in the eastern equatorial Pacific Ocean (i.e., ODP Leg 138) by Shackleton et al. (1995). We assume that the ages of the nannofossil datums are synchronous for the geographic area studied here (Erba, this volume). The validity of this assumption will need to be examined in future studies. Studies of calcareous nannoflora and orbitally calibrated oxygen isotope records from the North Atlantic and equatorial Pacific Ocean demonstrate the range of potential errors related to this assumption of synchroneity (Raffi et al., 1993; Wei, 1993).

\section{RESULTS AND DISCUSSION}

This paper presents the combined results of studies of the finegrained terrigenous (mineral dust) component of pelagic sediment from the Marshall Islands (Holes 871 A, 872A, and 873B on Limalok, Lo-En, and Wodejebato guyots, respectively; Rack, Bohrmann and Hobbs, this volume) and on Takuyo-Daisan Guyot near Japan (Hole $880 \mathrm{~A}$; see Rack, Lawyer and Gee, this volume; Fenner, this volume), and quantitative studies of Quaternary nannofossil biostratigraphy from these same sites (see Erba, this volume). Siliceous microfossils are restricted to the uppermost few meters of the pelagic cap sediments on each of these guyots, whereas late Pliocene to Quaternary calcareous nannofloras are found to be very abundant and well preserved at these sites.

Published results of terrigenous mineral (eolian) studies from additional ODP and piston core site locations from the boundaries and interior of the (Northern Hemisphere) Pacific Subtropical Gyre are used to provide additional comparisons among several high-quality mineral flux records. The high-resolution mineral record from Hole $810 \mathrm{C}$ on Shatsky Rise will be highlighted, as it provides a long-term (>3 m.y.) marine eolian record that can potentially provide correlations to the continental record of climate preserved by alternating soil/loess horizons in Asia.

\section{Results from Tropical Pacific Sites}

\section{Sites 871,872 , and 873}

Site 871 is located on the south central portion of Limalok Guyot, in the Ratak Chain of the southern Marshall Islands (Table 1 and Fig.
1). The sediments in the pelagic cap at Site $871(0-133.7$ meters below seafloor [mbsf]) consist of foraminifer nannofossil ooze and foraminifer ooze of Pleistocene to early Miocene age. The pelagic cap is divided into two subunits by a disconformity at $26.5 \mathrm{mbsf}$, where overlying light gray nannofossil foraminifer ooze of Pleistocene to latest Miocene age changes to white homogeneous foraminifer ooze of middle to early Miocene age below. The sediment in the lower portion of the pelagic cap is well-sorted and winnowed, with a medium-sand grain size. The disconformity, spanning the upper middle Miocene through most of the upper Miocene (approx. 6 m.y.), marks a major change in sediment accumulation on this guyot (Premoli Silva, Haggerty, Rack, et al., 1993), which may correspond to an intensification of intermediate water flow in response to cooling at high southern latitudes.

The pelagic cap at Site 872 on Lo-En Guyot (Table 1 and Fig. 1) consists of an upper lithologic subunit of white to very pale brown nannofossil foraminifer ooze and intercalated foraminifer ooze of Pleistocene to late Miocene age ( $30-32 \mathrm{~m}$ thick), and a lower subunit of very pale brown homogeneous foraminifer ooze, which is well sorted, winnowed, with a medium-sand grain size, and is of late Miocene to late Oligocene age. The transition between the two subunits is marked by a physically mixed and incomplete interval of nannofloras and faunas of different zones, which spans the upper middle to lower upper Miocene, overlain by a disconformity (Premoli Silva, Haggerty, Rack, et al., 1993).

Site 873 is situated on the south central summit of Wodejebato Guyot, in the Ralik Chain of the northern Marshall Islands (Table 1 and Fig. 1). The pelagic cap on Wodejebato Guyot consists of an upper lithologic subunit of light gray nannofossil foraminifer ooze of Pleistocene to latest Miocene age; whereas, the lower subunit is composed of a well-sorted and winnowed, very pale brown, mainly homogeneous foraminifer ooze with a medium-sand grain size, and it is of middle to early Miocene age. The transition between the two subunits is marked by a disconformity spanning most of the upper middle and upper Miocene (Premoli Silva, Haggerty, Rack, et al., 1993).

Diatoms at Sites 871,872 , and 873 are scarce, poorly preserved and exhibit low diversity (Fenner, this volume). Conversely, abundant nannofossils were observed throughout the Quaternary sequences at Sites 871,872 , and 873 . Because of the relatively shallow water depths of the studied sites, nannofloras are well preserved to moderately preserved (Erba, this volume).

\section{Sedimentologic and Biostratigraphic Results}

Weight percentages and MARs of calcium carbonate and finegrained mineral material at Holes $871 \mathrm{~A}$ and $873 \mathrm{~B}$ are given by Rack, Bohrmann, and Hobbs (this volume). Determinations of the weight percentage of calcium carbonate were also made at Site 872, allowing the noncarbonate weight percentage of the bulk sediment to be qualitatively estimated $\left(100 \%-\mathrm{wt} \% \mathrm{CaCO}_{3}=\right.$ noncarbonate); however, no mineral extractions were made at this site.

Measurements of the weight percentage of the $\mathrm{CH}_{3} \mathrm{COOH}$-insoluble residue $(>2 \mu \mathrm{m})$ were also made by Fenner (this volume) at Holes $871 \mathrm{~A}, 872 \mathrm{~A}, 872 \mathrm{C}$, and $873 \mathrm{~B}$. This residue will contain mineral dust, ash, opal, and organic carbon. These measurements, although limited to the upper core at each hole, are in general agreement with the qualitative trends presented by Rack, Bohrmann and Hobbs (this volume) for the weight percentage of non-carbonate material.

Erba (this volume) reports a complete sequence of nannofossil events and biozones at Sites 871 and 872; however, at Site 873, most of the Quaternary is missing. The detection of only the lower Pleistocene nannofossil events at Site 873 suggests that the accumulation of pelagic sediments on Wodejebato Guyot is strongly affected by current activity (Premoli Silva, Haggerty, Rack, et al., 1993; Erba, this volume; Pearson, this volume). For depth correlations of the nannofloral zonal boundaries and more detailed discussion of the data from 
Table 2. Sub-bottom depth of nannofossil datums identified at selected Pacific Ocean ODP sites of relevance to this study.

\begin{tabular}{|c|c|c|c|c|c|c|c|c|c|c|c|c|}
\hline & Event & $\begin{array}{l}\text { Age } \\
\text { (Ma) }\end{array}$ & $\begin{array}{c}\text { Hole } \\
871 \mathrm{~A} \\
\text { (mbsf) }\end{array}$ & $\begin{array}{c}\text { Hole } \\
872 \mathrm{~A} \\
\text { (mbsf) }\end{array}$ & $\begin{array}{c}\text { Hole } \\
873 B \\
\text { (mbsf) }\end{array}$ & $\begin{array}{l}\text { Hole } \\
880 \mathrm{~A} \\
\text { (mbsf) }\end{array}$ & $\begin{array}{c}\text { Hole } \\
810 \mathrm{C} \\
\text { (mbsf) }\end{array}$ & $\begin{array}{l}\text { Hole } \\
803 \mathrm{D} \\
\text { (mbsf) }\end{array}$ & $\begin{array}{c}\text { Site } \\
853 \\
(\mathrm{mcd})\end{array}$ & $\begin{array}{c}\text { Site } \\
852 \\
\text { (mcd) }\end{array}$ & $\begin{array}{c}\text { Site } \\
849 \\
(\mathrm{mcd})\end{array}$ & $\begin{array}{c}\text { Site } \\
848 \\
\text { (mcd) }\end{array}$ \\
\hline FO & Acme E. huxleyi & 0.085 & 0.82 & 0.25 & & 1.80 & 0.41 & & & & & \\
\hline FO & E. huxleyi & 0.260 & 2.90 & 1.35 & & 4.80 & 2.61 & & & & & \\
\hline LO & P. lacunosa & 0.461 & 5.30 & 2.35 & & 5.20 & 5.66 & 18.24 & 2.75 & 4.80 & 13.30 & 6.05 \\
\hline Reentrance & Medium Gephyrocapsa & 1.028 & 9.25 & 4.75 & & 10.20 & & 23.63 & 4.03 & 11.68 & 28.81 & 16.37 \\
\hline LO & Large Gephyrocapsa & 1.240 & 12.25 & 6.25 & & 11.59 & 21.67 & 27.61 & & 14.68 & 33.90 & 19.55 \\
\hline $\mathrm{FO}$ & Large Gephyrocapsa & 1.457 & 13.35 & 7.30 & 3.07 & 13.17 & 24.84 & 29.90 & 5.93 & 18.30 & 39.86 & 23.20 \\
\hline LO & C. macintyrei & 1.597 & 16.35 & 7.55 & 3.57 & 14.57 & 28.28 & 32.90 & 6.68 & 20.28 & 44.05 & 24.32 \\
\hline FO & Medium Gephyrocapsa & 1.660 & & & & & & 37.40 & 7.32 & 20.28 & 47.05 & 24.47 \\
\hline $\mathrm{FO}$ & G. oceanica s.I. & 1.660 & 17.25 & 8.35 & 4.02 & 15.97 & & & & & & \\
\hline LO & D. brouweri & 1.960 & 18.35 & 8.85 & 4.97 & 16.37 & 28.28 & 43.71 & 7.70 & 21.73 & 59.35 & 26.92 \\
\hline LO & D. pentaradiatus & 2.440 & & & 7.84 & & & 49.35 & 11.17 & 28.92 & & 30.65 \\
\hline LO & D. surculus & 2.610 & & & & & 36.17 & & 13.05 & 32.83 & 71.00 & 30.65 \\
\hline LO & D. tamalis & 2.760 & 19.15 & & 10.63 & & 40.55 & & 14.45 & 34.33 & 77.20 & 32.09 \\
\hline LO & Sphenolithus spp. & 3.650 & & & & & & & 20.50 & 41.32 & 101.85 & 36.15 \\
\hline LO & $R$. pseudoumbilicus & 3.804 & & & 17.03 & & 57.78 & & 20.50 & 42.85 & 105.25 & 37.42 \\
\hline FO & Circular $D$, asymmetricus & 4.030 & & & & & & & 22.70 & 43.80 & & 38.70 \\
\hline LO & A. primus & 4.540 & & & & & & & 25.88 & 51.35 & & 40.26 \\
\hline LO & C. acutus & 4.970 & & & & & & & 29.15 & & & 47.20 \\
\hline $\mathrm{FO}$ & C. rugosus & 5.040 & & & & & 69.01 & & 29.74 & 56.45 & 157.25 & 50.90 \\
\hline FO & C. acutus & 5.340 & & & & & & 77.97 & 32.68 & 63.24 & 174.30 & 52.45 \\
\hline LO & T. rugosus & 5.340 & & & 21.31 & & & & & & 174.30 & \\
\hline LO & D. quinqueramus & 5.560 & & 21.75 & & & 75.21 & 79.81 & 32.68 & 66.32 & 189.65 & 57.13 \\
\hline
\end{tabular}

Notes: Nannofossil age model for Holes 871A, 872B, 873B, and 880A by Erba (this volume); for Hole $810 \mathrm{C}$ by Premoli Silva et al. (1993); for Hole 803D by Takayama (1993); and for Sites 853, 852, 849, and 848 by Raffi and Flores (1995) and Shackleton et al. (1995). mcd = meters composite depth. FO = first occurrence datum. and LO = last occurrence datum.

these sites, the reader is directed to the descriptions in Erba (this volume). Table 2 provides a summary of the ages and sub-bottom depths used to construct the age models and to plot the data from these holes.

In Hole $871 \mathrm{~A}$ on Limalok Guyot, there are three prominent increases in MAR at $\sim 1.5 \mathrm{Ma}, 1.2$ to $1.0 \mathrm{Ma}$, and $\sim 0.4 \mathrm{Ma}$, respectively (Fig. 2A). The terrigenous mineral flux (TMAR) is observed to be highest during the $\sim 1.5 \mathrm{Ma}$ and $\sim 0.4 \mathrm{Ma}$ increases in the overall rate, when the TMAR increases to $2-3$ times above its background flux values (from $\sim 3 \mathrm{mg}\left[\mathrm{cm}^{2} \times \text { k.y. }\right]^{-1}$ to $6-9 \mathrm{mg}\left[\mathrm{cm}^{2} \times \text { k.y. }\right]^{-1}$ ). The nannofloral abundance plots (Fig. 2B) show that the 0.4 Ma TMAR increase is positioned between a sharp decrease in the percentage of $G$. caribbeanica and an increase in the abundance of E. huxleyi. A qualitative increase is observed in the weight percentage of the $>2$ $\mu \mathrm{m}$-sized $\mathrm{CH}_{3} \mathrm{COOH}$-insoluble residue within this interval (Fenner, this volume), yielding an increased overall flux of insoluble material. The TMAR increase at $\sim 1.5 \mathrm{Ma}$ is associated with an overall increase in the abundance of the Gephyrocapsa group and is positioned just below the increase in the percentage of the large Gephyrocapsa species. These quantitative measures of nannofossil species abundance fluctuations may provide the means to evaluate changes in nannoflora with respect to changes in mineral fluxes, thereby constraining the ecologic and oceanographic interpretation of pelagic sediment accumulation patterns on these guyots.

In Hole $872 \mathrm{~A}$ on Lo-En Guyot, there are two prominent increases in the noncarbonate flux (NCAR), at $\sim 1.7-1.5 \mathrm{Ma}$ and at $\sim 1.2-1.0$ Ma, respectively. The former increase in noncarbonate flux (e.g., mineral component, plus biogenic opal, organic carbon, oxides, hydroxides and zeolites) represents an approximate doubling of the flux above background levels; the latter increase is more subtle (Fig. 3A). The increase in noncarbonate flux at $\sim 1.7-1.5 \mathrm{Ma}$ is associated with both an increase in the overall abundance of the Gephyrocapsa group and a subsequent increase in the percentage of large Gephyrocapsa species (see Fig. 3B).

In Hole 873B on Wodejebato Guyot, the upper part of the Quaternary is missing but there is a broad increase in TMAR from about 3.0-1.2 Ma. However, a subtle increase in mineral flux is again observed at $\sim 1.7-1.5 \mathrm{Ma}$ (Fig. $4 \mathrm{~A}$ ). There is an increase in the overall abundance of the Gephyrocapsa group since before about $2.0 \mathrm{Ma}$, but the subsequent increase in the percentage of the large Gephyrocapsa species is more diffuse (Fig. 4B), perhaps because of the effects of sediment reworking by currents around/over the pelagic cap of this guyot (Pearson, this volume).

\section{Discussion of Tropical and Equatorial Pacific Sites}

The combined results from Holes $871 \mathrm{~A}, 872 \mathrm{~A}$, and $873 \mathrm{~B}$, show increases in mineral flux to the region of the Marshall Islands at $\sim 2.3-1.5 \mathrm{Ma}$, at $\sim 1.2-1.0 \mathrm{Ma}$, and possibly at $\sim 0.4 \mathrm{Ma}$, respectively. We now compare the Marshall Island records with other sites in the north tropical and equatorial Pacific Ocean region, such as to the south, at Hole 803D on Ontong Java Plateau (Fig. 5; Krissek and Janecek, 1993), and in the eastern equatorial Pacific (ODP Leg 138; Sites 848, 849, 852, 853; Figs. 6-9; Hovan, 1995), which form a south-to-north latitudinal transect along $110^{\circ} \mathrm{W}$ to $109^{\circ} \mathrm{W}$ longitude.

The temporal resolution of data from any of these sites depends on the sample-spacing and the linear sedimentation rate at a particular site. Data from Hole 803D exhibit the lowest resolution for the inter$\mathrm{val}$ in question ( $0-3 \mathrm{Ma})$, Hole $849 \mathrm{~B}$ exhibits the highest resolution obtained. In this paper, only general comparisons will be made among these sites because of the complex nature of the proxy signal contained in the mineral flux records. Krissek and Janecek (1993) and Hovan (1995) provide detailed discussions and more extensive paleoenvironmental interpretations of these data.

The TMARs at sites located in the equatorial Pacific region are strongly influenced by the latitudinal position of the Intertropical Convergence Zone (ITCZ), which moves north and south in response to the changing strength of the northeast and southeast trade wind systems, both seasonally and over longer time scales. The ITCZ is characterized by light and variable winds and increased rainfall, with resulting wet-depositional scavenging of aerosol particles; the ITCZ thus forms an effective barrier to latitudinal eolian transport (for discussion, see Hovan, 1995). Therefore, the records of mineral dust fluxes at these equatorial sites may not entirely reflect Asian sources of mineral dust, but the cross-Pacific comparison may nonetheless be instructive. We will also examine the high-resolution eolian record from piston Core RC11-210 (Chuey et al., 1987; Rea et al., 1991), which was recovered from the central equatorial Pacific, between the eastern and western transects of sites discussed here.

Terrigenous mineral dust transported to Hole 803D on Ontong Java Plateau may originate from different sources and transport paths, including northeasterly and southeasterly trade winds, the Northern Hemisphere westerlies, or variable local winds (Krissek and Janecek, 1993). These authors have used mineral assemblage identifications to determine that Asian source areas beneath the Northern Hemisphere westerlies have exerted a stronger influence on the mineral assem- 


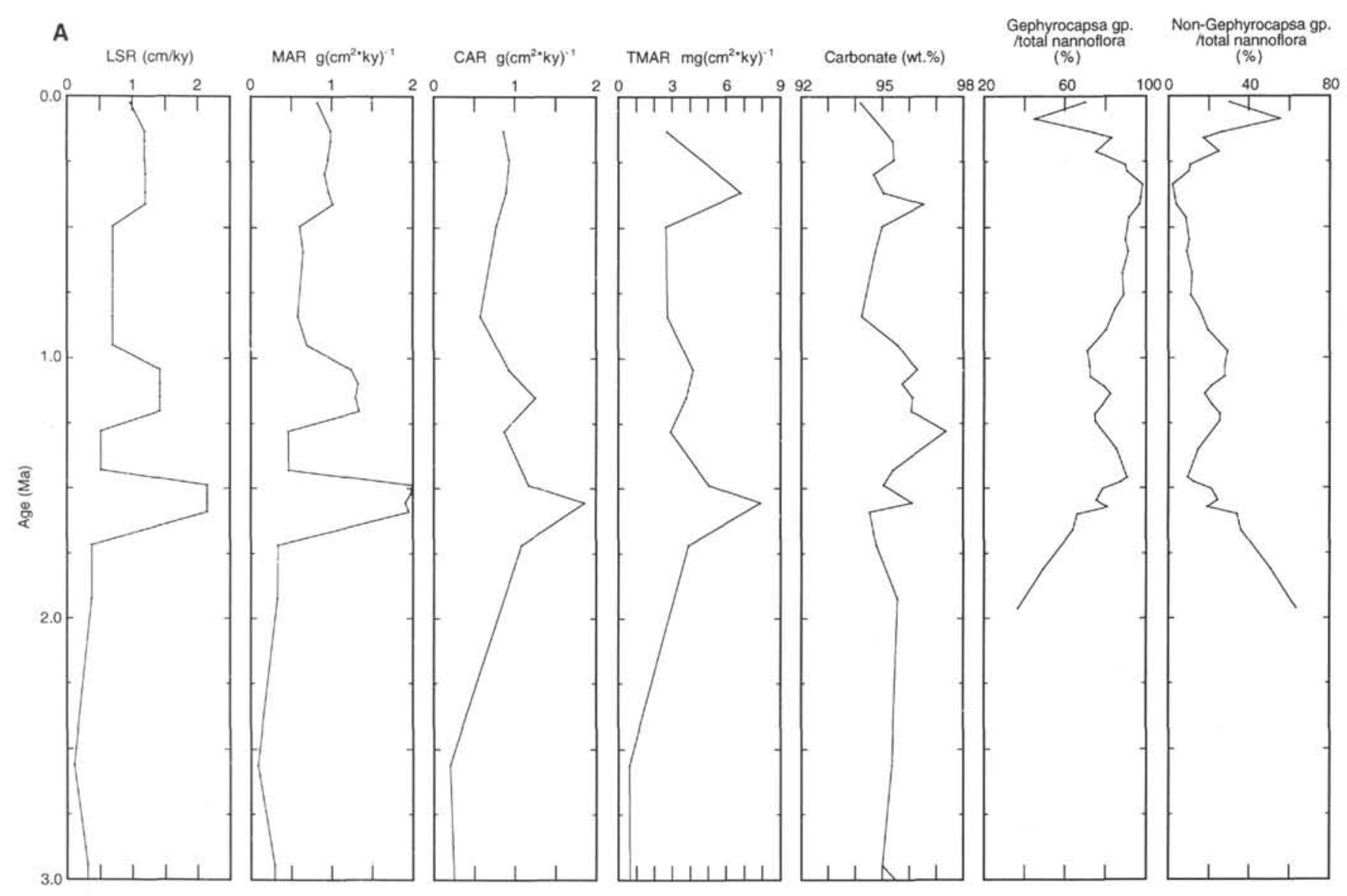

Figure 2. A. Summary plots of sedimentologic data and mass accumulation rates vs. age (0-3 Ma) in Hole 871A (Limalok Guyot). The plots are of linear sedimentation rate (LSR), mass accumulation rate (MAR), carbonate mass accumulation rate (CAR), terrigenous mass accumulation rate (TMAR), and the weight percentage of calcium carbonate. Note the change to units of $\mathrm{mg}\left(\mathrm{cm}^{2} \times \mathrm{k} . \mathrm{y} .\right)^{-1}$ for TMAR, relative to the other plots. Also shown are plots of the ratio of species of the Gephyrocapsa group and of the non-Gephyrocapsa group, relative to the total nannoflora, respectively. B. Summary of quantitative nannofossil biostratigraphy vs. age (Ma) in Hole 871A. Data are from Erba (this volume). Note: P. lacunosa $\mathrm{E}(\mathrm{E}=$ elliptical form).

blages brought to Ontong Java Plateau than Central or South American source areas beneath the easterlies.

From 0 to $3 \mathrm{Ma}$ at Hole $803 \mathrm{D}$, there are two broad intervals with higher mineral fluxes of approximately $90-100 \mathrm{mg}\left(\mathrm{cm}^{2} \times \mathrm{k} . \mathrm{y} .\right)^{-1}$ : one interval from $>3.0$ to $\sim 2.7 \mathrm{Ma}$ and one from $\sim 2.4$ to $1.6 \mathrm{Ma}$. These two intervals of higher mineral flux are followed by an apparent decline in the mineral flux uphole, before increasing again at about $0.5 \mathrm{Ma}$ (Fig. 5). The general trends in mass accumulation observed at Hole $803 \mathrm{D}$ are qualitatively similar to those identified at Hole $873 \mathrm{~B}$, located $1000 \mathrm{~km}$ to the north. However, the sampling resolution of both of these records are generally poor and more data are needed to resolve shorter intervals.

Berger et al. (1994) note large fluctuations in sedimentation rates (primarily caused by changes in carbonate accumulation) at Hole 806B, located upslope of Hole 803D on Ontong Java Plateau, with significant increases in sediment accumulation at $>2.0-1.8 \mathrm{Ma}, 1.5$ $\sim 1.3 \mathrm{Ma}, \sim 1.2-\sim 1.0 \mathrm{Ma}, \sim 0.6-0.5 \mathrm{Ma}$, and 0.4-0.2 Ma, respectively; these fluctuations suggest a climatic influence on carbonate accumulation on Ontong Java Plateau during the Quaternary ( 413 k.y. periodicity over the past 2 m.y.). No mineral data are presently available from Hole $806 \mathrm{~B}$. Future improvements in the spatial and temporal resolution of mineral studies could greatly improve our ability to make cross-equatorial comparisons between sites on the Ontong Java Plateau (south of the equator) and sites on Marshall Island guyots (north of the equator) in the western Pacific.

Holes 848B, 849B, 852B, and 853B form a south-to-north transect across the equator in the eastern Pacific. Terrigenous MAR values increase northward from the southern holes (Holes 848B and 849B) to Hole 852B, but decrease at Hole 853B (see Figs. 6-9). The detailed patterns of flux variability at each of these holes are highly complex; this suggests that an increased sampling resolution is necessary to show the true variability in these records. At Hole 853B, there is a gradual, overall decrease in mineral flux from 3 to $\sim 2.3 \mathrm{Ma}$, followed by a broad reversal in this trend (broad increase in mineral flux) from $\sim 2.3$ to $\sim 0.6 \mathrm{Ma}$ (Fig. 9). The mineral flux records from the sites to the south are more variable, with a more sawtooth pattern of variability being evident in the flux data (see Figs. 6-8).

Hovan (1995) notes that there are significant differences in the records of TMAR and grain size from north to south along this transect, and that there may have been a regional decrease in the supply of eolian material to the equatorial Pacific from eastern source regions (Central and South America) since the late Pliocene. The regional differences in records of eolian grain size and TMARs during the Quaternary may reflect a close relationship in the eastern equatorial $\mathrm{Pa}$ cific between changes in atmospheric circulation strength, equatorial upwelling, and regional biological productivity (Murray and Leinen, 1993; Murray et al., 1993; Rea, 1994; Snoeckx and Rea, 1994; Farrell et al., 1995; Hovan, 1995; Pisias et al., 1995; among others).

The Quaternary sequence recovered in piston Core RC11-210, located just north of the equator in the central Pacific Ocean, provides high-quality, high-resolution, proxy records of atmospheric and oceanic variability (Chuey et al., 1987; Rea et al., 1991; for site location, see Table 1 and Fig.1). Core RC11-210 is the best studied core from the equatorial Pacific (Rea, 1994). Summary plots of the weight 
B

E. huxleyi $(\%)$

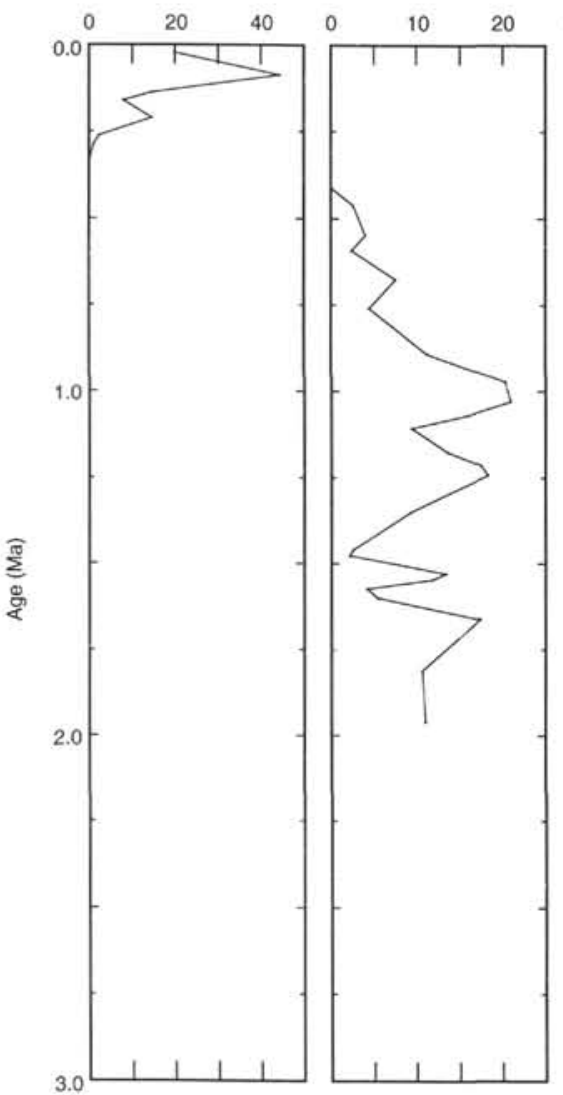

Sm. Gephyrocapsa (\%)

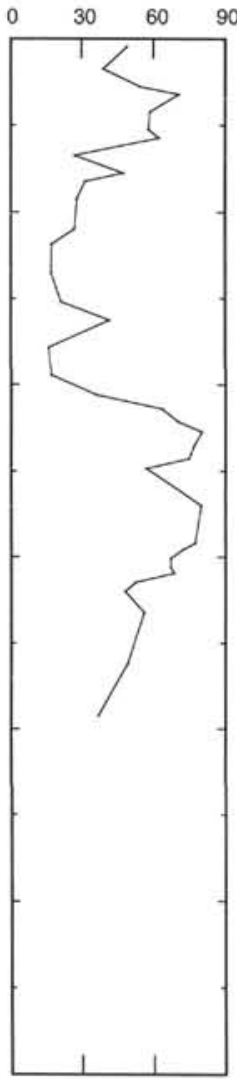

Lg. Gephyrocapsa (\%)

G.caribbeanica (\%)

G. oceanica (\%)
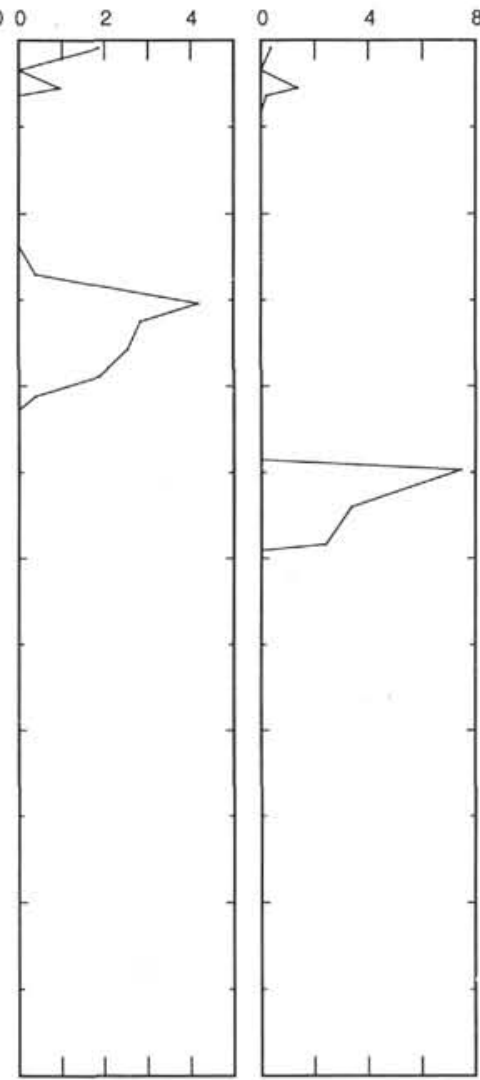

$\begin{array}{lllll}80 & 20 & 40 & 60\end{array}$

$\begin{array}{llll}0 & 10 & 20 & 30\end{array}$

Figure 2 (continued).

percentages of individual sedimentary components and corresponding mass accumulation rates are given in Figure 10A-B (data from Chuey et al., 1987; Rea et al., 1991). These plots illustrate the cyclical nature of these proxy records for the interval from 0 to $0.6 \mathrm{Ma}$, although there is a change in the nature of the variability of paleoclimatic proxy indicators at about 300 ka (Pisias and Rea, 1988; Rea, 1994). Changes in the median mineral grain size in this core have been interpreted as reflecting a northward latitudinal shift in the position of the ITCZ (of $\sim 5^{\circ}$ ) after oxygen isotope stage 9 (at $\sim 250$ $300 \mathrm{ka}$ ). This shift in the position of the ITCZ results in a change in source for the terrigenous dust being transported to this site (change from Asian to South American source) and a change from a pattern of higher TMARs during glacial stages before the shift, to a pattern of higher fluxes of mineral dust during interglacials after the shift (see Chuey et al., 1987; Rea, 1994).

\section{Results from Northwest Pacific Sites}

\section{Hole 880A}

Hole $880 \mathrm{~A}$ is located on Takuyo-Daisan Guyot (Table 1 and Fig. 1). Drilling at Hole $880 \mathrm{~A}$ penetrated $18.4 \mathrm{mbsf}$. One lithologic unit consisting of four different, interlayered lithologies occurs at this site. In order of decreasing abundance, these are: volcaniclastic sand, foraminifer sand, nannofossil-foraminifer ooze, and volcanic ash (Premoli Silva, Haggerty, Rack, et al., 1993).

Recovered sediment ranges in color from shades of yellow-green and grayish brown to very dark gray. Increasing darkness typically is related to the increasing percentage of coarse-grained volcanic material, although light-colored volcanic ashes are also observed (see Rack, Lawyer, and Gee, this volume). Nonbiogenic components include feldspars, opaque minerals (possibly manganese nodules), ve- sicular lava fragments, volcanic lapilli, scoriaceous basalt grains, and pyrite (Premoli Silva, Haggerty, Rack, et al., 1993). Diatoms, sponge spicules, and silicoflagellates are frequent in the uppermost layers, but they decrease in abundance downhole (Premoli Silva, Haggerty, Rack, et al., 1993; Fenner, this volume). These hemipelagic sediments were deposited under the episodic influence of volcanic eruptions from the nearby convergent margin setting, which may have helped to preserve some of the more dissolution resistant biosiliceous microfossils (Fenner, this volume); continental runoff from Japan and/or China (as influenced by currents) also may have contributed to the amount of lithogenic material accumulating at this site. The recovered section at Hole $880 \mathrm{~A}$ provides a condensed, but almost complete, Holocene to uppermost Pliocene sequence; a hiatus was detected in the upper Pleistocene where the G. oceanica Zone is extremely short (Erba, this volume).

\section{Sedimentologic and Biostratigraphic Results, Hole $880 \mathrm{~A}$}

Eleven nannofossil biostratigraphic events and eight biozones were recognized at this site (see Table 2) and were calibrated to the magnetostratigraphy (Erba, this volume). These ages assigned to these events have been used with compositional data and dry bulk density values from Rack, Lawyer and Gee (this volume) to calculate mass accumulation rates for individual sedimentary components in Hole 880A (see Appendix A). Temporal fluctuations in MARs and in variations of the dominant nannofloral groups are shown in Figure $11 \mathrm{~A}$; Figure 11B shows changes in the relative abundance of individual nannofossil species (Erba, this volume). Near-continuous wholecore measurements of GRAPE bulk density and magnetic susceptibility are shown in Figure 12, along with plots of estimated dry bulk density, the weight percentages of coarse-grained and fine-grained 
A

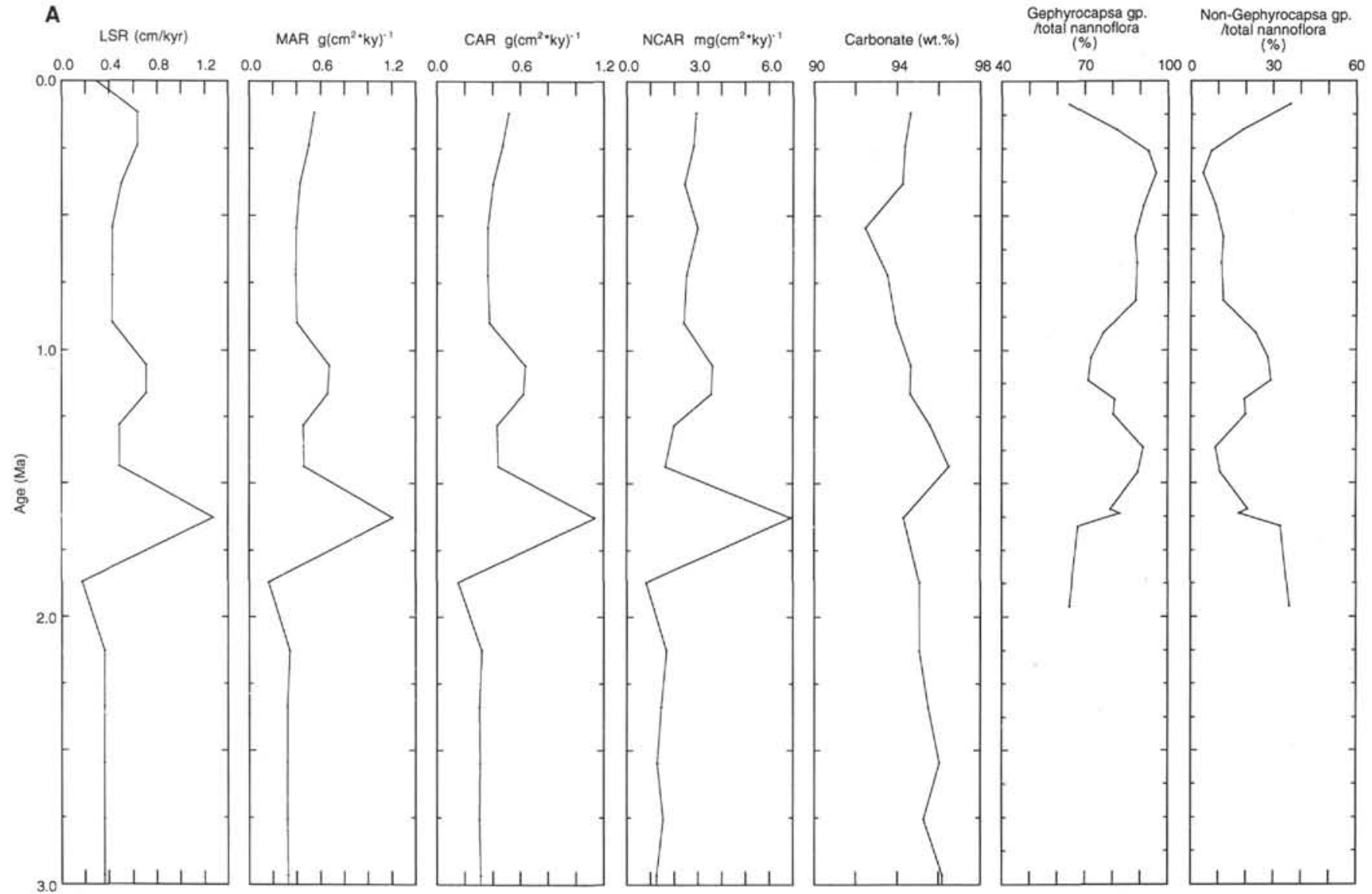

Figure 3. A. Summary plots of sedimentologic data and mass accumulation rates vs. age ( $0-3 \mathrm{Ma})$ in Hole $872 \mathrm{~A}$ (Lo-En Guyot). NCAR $=$ noncarbonate mass accumulation rate. B. Summary of quantitative nannofossil biostratigraphy vs. age (Ma) in Hole 872A. Data are from Erba (this volume). Note: P. lacunosa E (E $=$ elliptical form).

mineral components (terrigenous and volcanic grains; Rack, et al., this volume), insoluble residues of the bulk sediment (Fenner, this volume), and the positions of ash and pumice layers in Hole 880A.

The highest MARs in Hole $880 \mathrm{~A}$ are observed from $\sim 1.7$ to 1.5 $\mathrm{Ma}$, and from $0.25 \mathrm{Ma}$ to the top of the hole (Fig. 11A); the latter interval is associated with declines in the relative abundance of $G$. oceanica and small Gephyrocapsa species, and an increase in the abundance of $E$. huxleyi (Fig. 11B). In these two intervals, the total MAR values range from $2.0 \mathrm{~g}\left(\mathrm{~cm}^{2} \times \mathrm{k} . \mathrm{y} .\right)^{-1}$ to $4.0 \mathrm{~g}\left(\mathrm{~cm}^{2} \times \mathrm{k} . \mathrm{y} .\right)^{-1}$, with the highest values occurring from $\sim 1.7$ to $1.5 \mathrm{Ma}$; fine-grained terrigenous mass accumulation rates (TMARs) range from 400 to $800 \mathrm{mg}\left(\mathrm{cm}^{2} \times \mathrm{k} . \mathrm{y} .\right)^{-1}$ and $300 \mathrm{mg}\left(\mathrm{cm}^{2} \times \mathrm{k} . \mathrm{y} \text {. }\right)^{-1}$, respectively, within these two intervals (Fig. 11A).

The high values of MARs and TMARs at $\sim 1.7-1.5 \mathrm{Ma}$ are associated with a decline in the relative abundance of $G$. caribbeanica and an increased dominance of the $P$. lacunosa $\mathrm{E}$ species of nannoflora $(\mathrm{E}$ $=$ elliptical; $40 \%-60 \%$ of the total nannoflora in this interval); additional increases in the abundance of $P$. lacunosa $\mathrm{E}$, from $\sim 1.2$ to 1.0 $\mathrm{Ma}$ and from $\sim 0.8$ to $0.5 \mathrm{Ma}$, are not associated with greatly increased MAR values. Sediment accumulation rates throughout the interval from $\sim 1.5$ to $0.4 \mathrm{Ma}$ are approximately $1.0 \mathrm{~g}\left(\mathrm{~cm}^{2} \times \mathrm{k} . \mathrm{y} \text {. }\right)^{-1}$.

Figure 13 provides an expanded version of the data from Hole $880 \mathrm{~A}$ for the interval from 0 to $0.6 \mathrm{Ma}$. Although Hole $880 \mathrm{~A}$ is clearly a hemipelagic site, an understanding of the MARs of the various sedimentary components at this site near Japan may provide information about the relative intensity of western boundary ocean currents and the timing of arc-related volcanism in the general vicinity of Takuyo-Daisan Guyot.

\section{Preliminary Identification of Ash Beds, Hole $880 \mathrm{~A}$}

The close proximity of Hole $880 \mathrm{~A}$ to sources of volcanism in and around Japan suggests that this hole might be used to develop an integrated nannofossil biostratigraphy and tephrochronology for this area of the Pacific Ocean. Hole 880A lies almost directly eastward of areas of extensive Pliocene-Pleistocene arc magmatism in Kyushu and southern to central Honshu (Kamata, 1989; Kamata and Kodama, 1994; Machida and Arai, 1983; Shimuzu and Itaya, 1993); therefore, the prevailing westerly winds would have transported material erupted from these volcanoes towards Hole 880A. Approximately 13 discrete ash layers have been identified in Hole 880A (Table 3; Premoli Silva, Haggerty, Rack, et al., 1993; Rack, Lawyer, and Gee, this volume); there may also be additional layers of disseminated ash and coarsegrained volcaniclastic particles which are not identified here.

Five widespread ashes of late Quaternary age have been identified on land and in deep-sea sediments around Japan according to Machida and Arai (1983). Three of these ashes are subalkalic tephras that have been correlated with large-scale eruptions that produced voluminous pyroclastic-flows and calderas in Kyushu, upwind of Hole 880A; these are the Kikai-Akahoya ash $\left(\mathrm{K}-\mathrm{Ah} ; \mathrm{C}^{14}\right.$ age $\left.=6.3 \mathrm{ka}\right)$, Aira-Tn ash (AT; $\mathrm{C}^{14}$ age $=\sim 21-23 \mathrm{ka}$ ), and the Aso-4 ash (U-Th age $=\sim 80 \mathrm{ka}$; Furuta et al., 1986; Machida and Arai, 1976, 1978, 1983, 1988).

An examination of the data contained in Rack, Lawyer, and Gee (this volume) and in Appendix A of this paper, suggests that at least two of these ashes are observed in Hole 880A. Based on observed increases in TMARs (and inferred quantities of coarse-grained material in the "unknown" fraction of the bulk sediment), we postulate that 
B

E. huxleyi $(\%) \quad$ P. lacunosa $E(\%)$

Sm. Gephyrocapsa (\%)

Gephyrocapsa sp. $3(\%)$

Lg. Gephyrocapsa (\%)

G. caribbeanica $(\%)$

G. oceanica (\%)

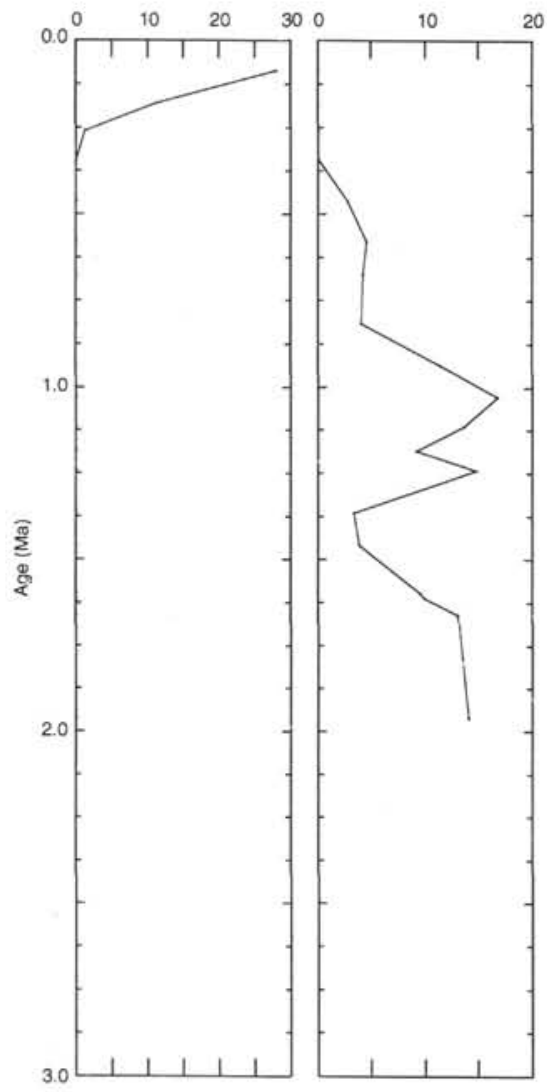

$200 \quad 40 \quad 80$

$\begin{array}{lll}0 & 2\end{array}$

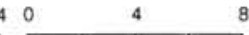

80
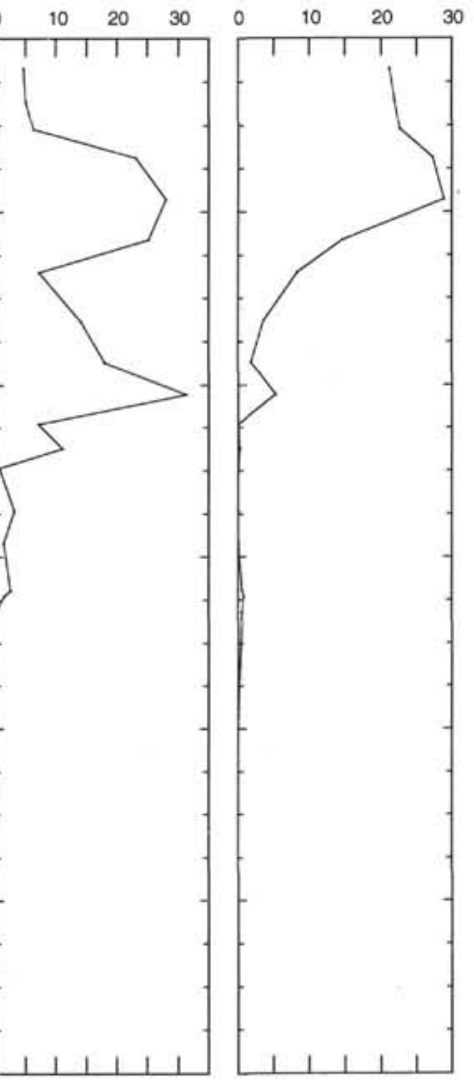

Figure 3 (continued).

the AT ash lies at $\sim 0.5-0.6 \mathrm{mbsf}$ and that the Aso- 4 ash lies at $~ 1.6-1.7$ mbsf in Hole $880 \mathrm{~A}$. The presence of an ash layer located at approximately $50 \mathrm{~cm}$ from the sediment surface is confirmed by Fenner (this volume), who observed a significant increase in vesicular ash above background levels in Sample 144-880A-1H-1, $53 \mathrm{~cm}$. At this time, measurements of the refractive index and mineralogy of these ashes have not been made.

Furuta et al. (1986) describe the AT ash as being fine-grained and well-sorted, with the glass fraction exceeding $90 \%$ of the entire material. The approximate age of this ash layer in Hole $880 \mathrm{~A}$ has been estimated to be $24-28 \mathrm{ka}$, assuming constant sedimentation between the sediment surface (age $=0.0$ ) and an age of $85 \mathrm{ka}$ for the acme of $E$. huxleyi at $1.80 \mathrm{mbsf}$. This age estimate is considered to be reasonable for establishing a probable correlation of this layer with the AT ash.

The Aso- 4 ash is recognized as having the longest-distance distribution of the five tephras studied by Furuta et al. (1986), occurring $1440 \mathrm{~km}$ away from its source (Aso Volcano in central Kyushu). Furuta et al. (1986) describe this tephra as having bubble-wall glass shards that are pale brown in color. They find this ash to be $2 \mathrm{~cm}$ thick, and located at $143 \mathrm{~cm}$ from the top of Core KH80-3-12, which is located near Hole $880 \mathrm{~A}$. Using the same dating criteria described above, the approximate age of the ash layer at 1.6-1.7 mbsf in Hole $880 \mathrm{~A}$ is $76-80 \mathrm{ka}$. This age estimate is considered to be reasonable for establishing a probable correlation of this layer with the Aso- 4 ash.

\section{Hole $810 \mathrm{C}$}

Hole $810 \mathrm{C}$, located atop Shatsky Rise at intermediate water depths, was drilled during ODP Leg 132 (for location, see Table 1 and Fig. 1). Hole $810 \mathrm{C}$ penetrated $136.1 \mathrm{mbsf}$, mostly using the APC, with a total recovery of $143.8 \mathrm{~m}$ of nannofossil ooze. Two lithologic units
Table 3. Postulated ash or pumice layers in Hole 880A.

\begin{tabular}{|c|c|c|c|}
\hline $\begin{array}{l}\text { Depth } \\
\text { (mbsf) }\end{array}$ & Dominant lithology & $\begin{array}{c}\text { Thickness } \\
(\mathrm{cm})\end{array}$ & $\begin{array}{l}\text { Age } \\
\text { (Ma) }\end{array}$ \\
\hline $0.50-0.53$ & Ash & & 0.026 \\
\hline $1.60-1.70$ & Ash & & 0.078 \\
\hline $2.11-2.16$ & Volcaniclastic sand & 5 & 0.105 \\
\hline $2.60-2.72$ & Volcaniclastic sand & 12 & 0.136 \\
\hline $3.50-3.54$ & Ash & 4 & 0.185 \\
\hline 3.70 & Volcaniclastic sand & 1 & 0.196 \\
\hline 4.30 & Volcaniclastic sand & 1 & 0.231 \\
\hline 5.4 & Ash & $i$ & 0.484 \\
\hline $6.40-6.45$ & Ash & 5 & 0.599 \\
\hline $6.85-6.95$ & Ash & 10 & 0.654 \\
\hline 7.97 & Ash & 1 & 0.776 \\
\hline $8.95-9.80$ & Disseminated ash layers & & \\
\hline 9.50 & Volcanic lapilli & & 0.947 \\
\hline 9.85 & Volcanic lapilli & & 0.988 \\
\hline $9.88-10.07$ & Ash & 19 & 1.004 \\
\hline $11.2-11.7$ & Disseminated ash layers & & \\
\hline 11.3 & Volcanic lapilli & & 1.194 \\
\hline 11.5 & Volcanic lapilli & & 1.230 \\
\hline 12.5 & Ash & & 1.420 \\
\hline 12.9 & Ash & & 1.490 \\
\hline $14.40-14.45$ & Ash & 5 & 1.592 \\
\hline $15.65-15.70$ & Ash & & 1.647 \\
\hline 16.47 & Ash & & 2.035 \\
\hline $17.30-17.60$ & Ash & 30 & 2.740 \\
\hline
\end{tabular}

were described in the upper 76 mbsf of this hole (Storms, Natland, et al., 1992). The upper unit consists of Pleistocene and younger, brown to dark gray nannofossil ooze with abundant siliceous microfossils ( $0-4.2 \mathrm{mbsf})$. There is evidence for cut and fill structures in the uppermost core, which suggest that significant erosional and/or sediment transport processes may have occurred in this upper unit. The lower unit consists of late Pliocene to Pleistocene light gray to white nannofossil ooze (4.2-76.0 mbsf). In the lower half of this lower unit, 


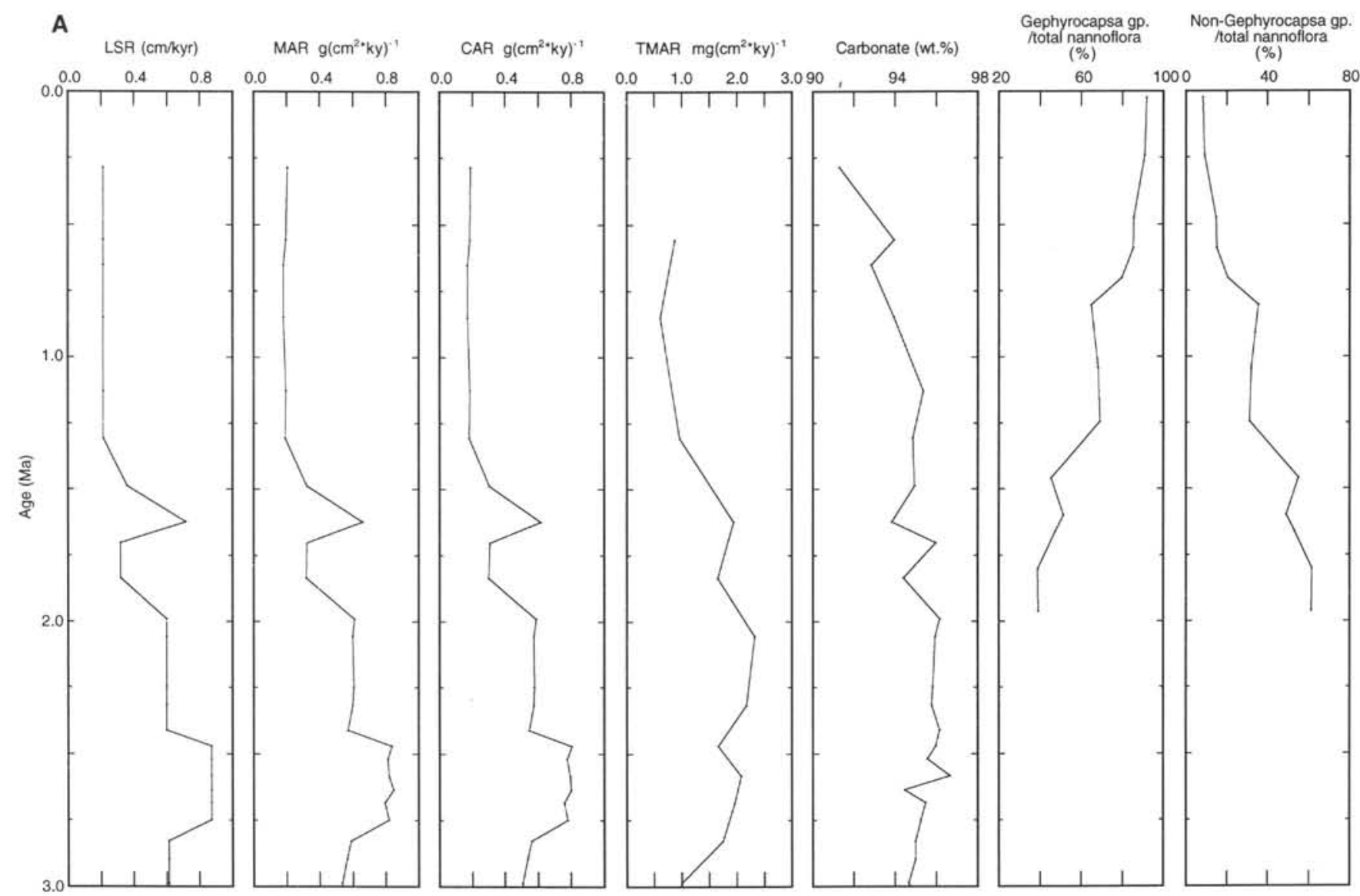

Figure 4. A. Summary plots of sedimentologic data and mass accumulation rates vs. age ( $0-3 \mathrm{Ma}$ ) in Hole $873 \mathrm{~B}$ (Wodejebato Guyot). B. Summary of quantitative nannofossil biostratigraphy vs. age (Ma) in Hole 873B. Data taken from Erba (this volume). Note: $P$. lacunos $\mathrm{E}=$ elliptical form; $\mathrm{C}=\mathrm{circular}$ form.

the light gray and white beds alternate at $40-$ to 80 -cm intervals. Several thin ash beds and pumiceous pebbles are present in Hole $810 \mathrm{C}$; these may be correlated to ash and pumice layers at other northwest Pacific sites (Natland, 1993).

\section{Sedimentologic Results and Biostratigraphy, Hole 810C}

The results from nearly 1000 determinations of the weight percentage of calcium carbonate in samples at approximately $5-\mathrm{cm}$ sample spacing in Hole 810C have been presented by Rack et al. (1993); estimates of the noncarbonate weight percentage of the bulk samples were also made $(100 \%-\%$ carbonate $=\%$ noncarbonate $)$. In this synthesis, the results from 400 chemical extractions of the weight percentage of fine-grained lithogenic material in bulk samples from Hole $810 \mathrm{C}$ are presented (see Appendix B and Fig. 14A).

The weight percentage of the "unknown" component in Hole $810 \mathrm{C}$ samples has been calculated using the "difference" method, where: $100 \%-\left(w t \% \mathrm{CaCO}_{3}+\mathrm{wt} \%\right.$ fine-grained lithogenic $)=\mathrm{wt} \%$ unknown material. The "unknown" component includes biogenic opal, coarse-grained lithogenic particles, organic carbon, $\mathrm{Mn}$ and $\mathrm{Fe}$ oxides, hydroxides and zeolites, which have all been removed from the extracted samples by the chemical procedure (see methods). This estimate is used to provide a crude measure of the additional material fluxes to the seafloor at this site. The laboratory results, "difference" calculations, and calculated mass accumulation rates for these components are plotted vs. age in Figures 14A and 14B. Natland (1993) identified the stratigraphic position of numerous ash and pumice layers in Hole 810C; these are shown in Figure 14A. The relative contribution of volcanic material to the overall mineral flux (finegrained and coarse-grained) is unknown at this time.
Clearly defined magnetic polarity zones provide a high-quality magnetic stratigraphy through the base of the Gilbert Chron, at approximately 76.8 mbsf in Hole 810C (Sager et al., 1993). Semi-quantitative biostratigraphic data were used to identify nannofossil zones based on the percentages of various species of the Gephyrocapsa group for the Pliocene to Holocene; foraminifer datums become progressively more important for age assignments with increasing sub-bottom depth in the section (see Table 2; Premoli Silva et al., 1993). Similar techniques were used at Holes $880 \mathrm{~A}$ and $810 \mathrm{C}$ to identify the nannofossil boundaries (see Erba, this volume; Premoli Silva et al., 1993).

The results of laboratory analyses on samples from Hole $810 \mathrm{C}$ are used to calculate linear sedimentation rates and sediment mass accumulation rates for the various components (Appendix C and Fig. 14B). Hole $810 \mathrm{C}$ provides a high-resolution record of biogenic and lithogenic sediment accumulation from almost directly downwind of Hole 880A and Asian sources of eolian materials. The character of both the carbonate and fine-grained terrigenous weight percentage fluctuations in Hole $810 \mathrm{C}$ provide clear evidence of cyclicity in these records (Fig. 14A); higher frequency fluctuations for the late Pliocene change to longer period undulations for the Quaternary. Two intervals of very low sediment accumulation or nondeposition are clearly evident in the plot of linear sedimentation rate (Fig. 14B); the first is from $\sim 1.9$ to $\sim 1.6 \mathrm{Ma}$, and the second is from $\sim 1.25$ to $\sim 1.0 \mathrm{Ma}$. A large and seemingly abrupt increase in linear sedimentation rate and mass accumulation occurs at approximately $0.8 \mathrm{Ma}$ in Hole $810 \mathrm{C}$ (Fig. 14B). This increase is followed by two to three, large-amplitude, undulations in the accumulation of both carbonate and mineral components in the younger record (Fig. 14B).

Although there are still significant fluctuations in the weight percentages of sedimentary components in the upper part of Hole 810C 
B

$\begin{array}{llllll}\text { P. lacunosa E (\%) P. lacunosa C (\%) Reticulofenestra spp. }(\%) & \text { sm. Gephyrocapsa (\%) } & \text { G. oceanica (\%) } & \text { G. caribbeanica (\%) } \quad \text { Lg. Gephyrocapsa (\%) }\end{array}$

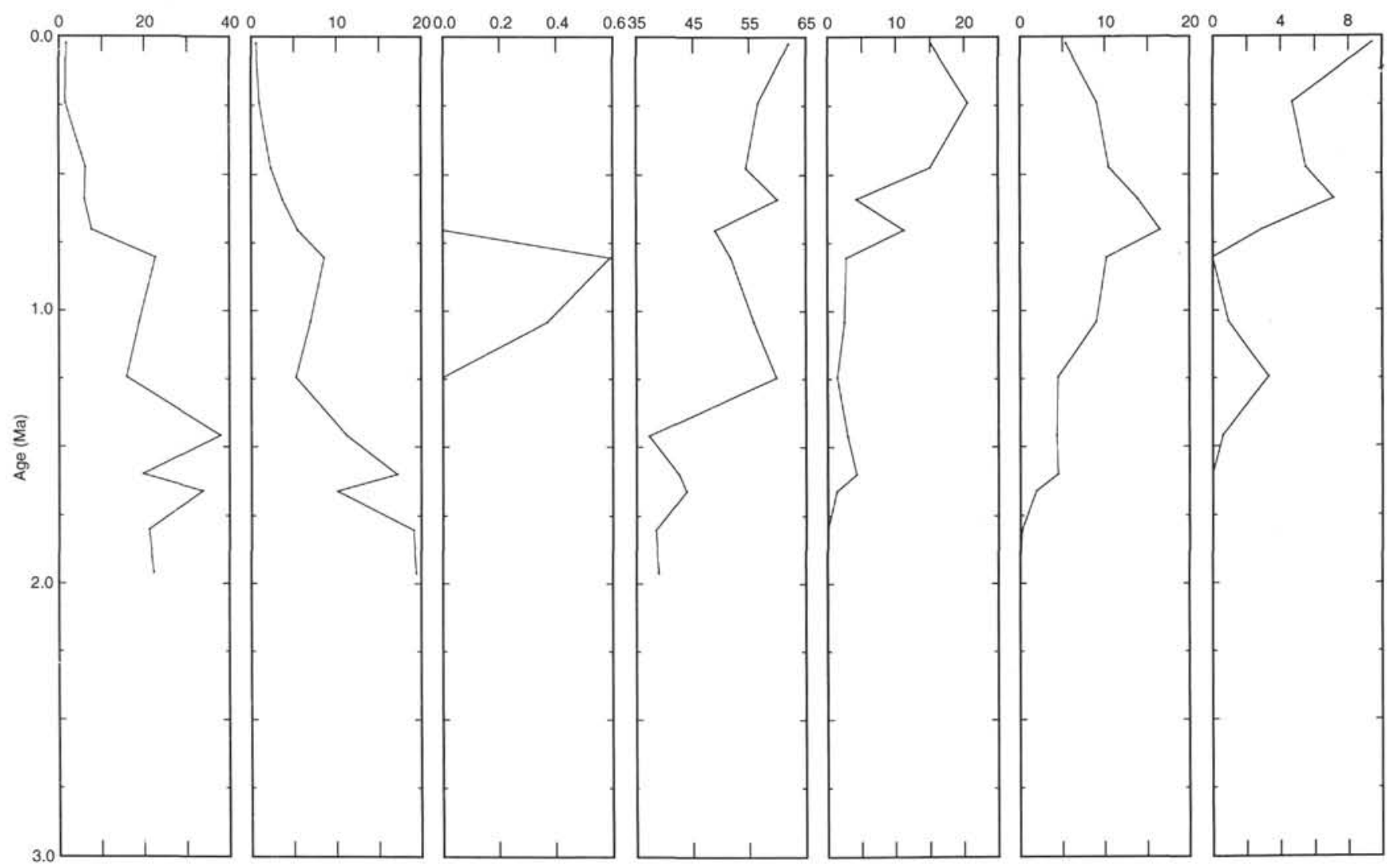

Figure 4 (continued).

from 0.6 to $\sim 0.3 \mathrm{Ma}$, the quality of the record above this level is poor (Fig. 15A); it is condensed and probably incomplete as indicated by the presence of cut-and-fill structures in Core 132-810C-1H (Storms, Natland, et al., 1992). MARs decrease abruptly at $\sim 0.45 \mathrm{Ma}$, from values of $3.0-4.0 \mathrm{~g}\left(\mathrm{~cm}^{2} \times \mathrm{k} . \mathrm{y} \text {. }\right)^{-1}$ to values of $1.0-1.5 \mathrm{~g}\left(\mathrm{~cm}^{2} \times \mathrm{k} . \mathrm{y} .\right)^{-1}$ (Fig. 15B). Studies are presently underway to improve the age model and sampling resolution in the uppermost sections of this hole.

\section{Discussion of Northwest Pacific Sites}

The sedimentologic results from Hole $810 \mathrm{C}$ provide a highresolution record of biogenic and lithogenic sediment accumulation from a locality at intermediate water depths on southern Shatsky Rise. The record exhibits clear evidence of cyclicity in the character of both carbonate and eolian weight percentage fluctuations, with higher frequency fluctuations in the late Pliocene changing to longer period undulations in the Quaternary.

Piston Core V21-146 provides the best high-resolution record from northern Shatsky Rise for the past $\sim 530$ k.y. (Hovan et al., 1989, 1991). In the following paragraphs, these two records from Shatsky Rise and a third record from piston Core KK 75-02, located just west of Hess Rise will be discussed as being the best marine eolian records presently available from the northwest Pacific. With future adjustments to their individual age models, they provide the opportunity for improved long-term correlations between marine records of paleoclimate and the loess/soil records of continental paleoclimate from central China.

\section{Piston Core V21-146}

One of the best examples of a continuous record of Quaternary climatic and oceanic conditions in the northwest Pacific over the past
530,000 years is the pelagic sediment record provided by Core V21146 (Hovan et al., 1989, 1991; for location, see Table 1 and Fig. 1). Studies of this core have allowed direct comparisons to be made between the record of mineral dust transport to the Pacific Ocean, the SPECMAP oxygen isotope record, and the magnetic susceptibility record from continental loess deposits at Xifeng, China (Hovan et al., 1989, 1991; Kukla et al., 1990).

The primary data from Core V21-146 are listed in Table 2 of Hovan et al. (1991); however, in this manuscript, additional values have been calculated in order to estimate the weight percentage and mass accumulation rates of the noncarbonate fraction of the bulk sediment $(100 \%-\%$ carbonate $=\%$ noncarbonate $)$, and the weight percentage of the "unknown" component of the bulk sediment $\left(100 \%-\left[\mathrm{wt} \% \mathrm{CaCO}_{3}+\mathrm{wt} \%\right.\right.$ Eolian (ash free $)+\%$ ash $]=\%$ unknown component). The "unknown" components are those materials that are dissolved during the extraction procedure and have not been otherwise measured (e.g., biogenic opal, sand-sized volcanic grains, organic carbon, Fe and Mn oxides, hydroxides, and zeolites; see methods); we expect that the weight percentage of biogenic opal, from diatom and radiolarian skeletons, makes up a significant percentage of the unknown fraction at this site.

The summary plots of the weight percentages and mass accumulation rates of individual components (Fig. 16A-B) show that the combined volcanic ash and "unknown" components of the bulk sediment $(20 \%-50 \%$ of the total) make a potentially large contribution to the noncarbonate accumulation at this site, in addition to the mineral dust flux. A better understanding of the composition of these unknown (undetermined) components of the bulk sediment may help to provide improved linkages between continental records of paleoclimate, atmospheric processes, and biological or chemical processes in the ocean. 


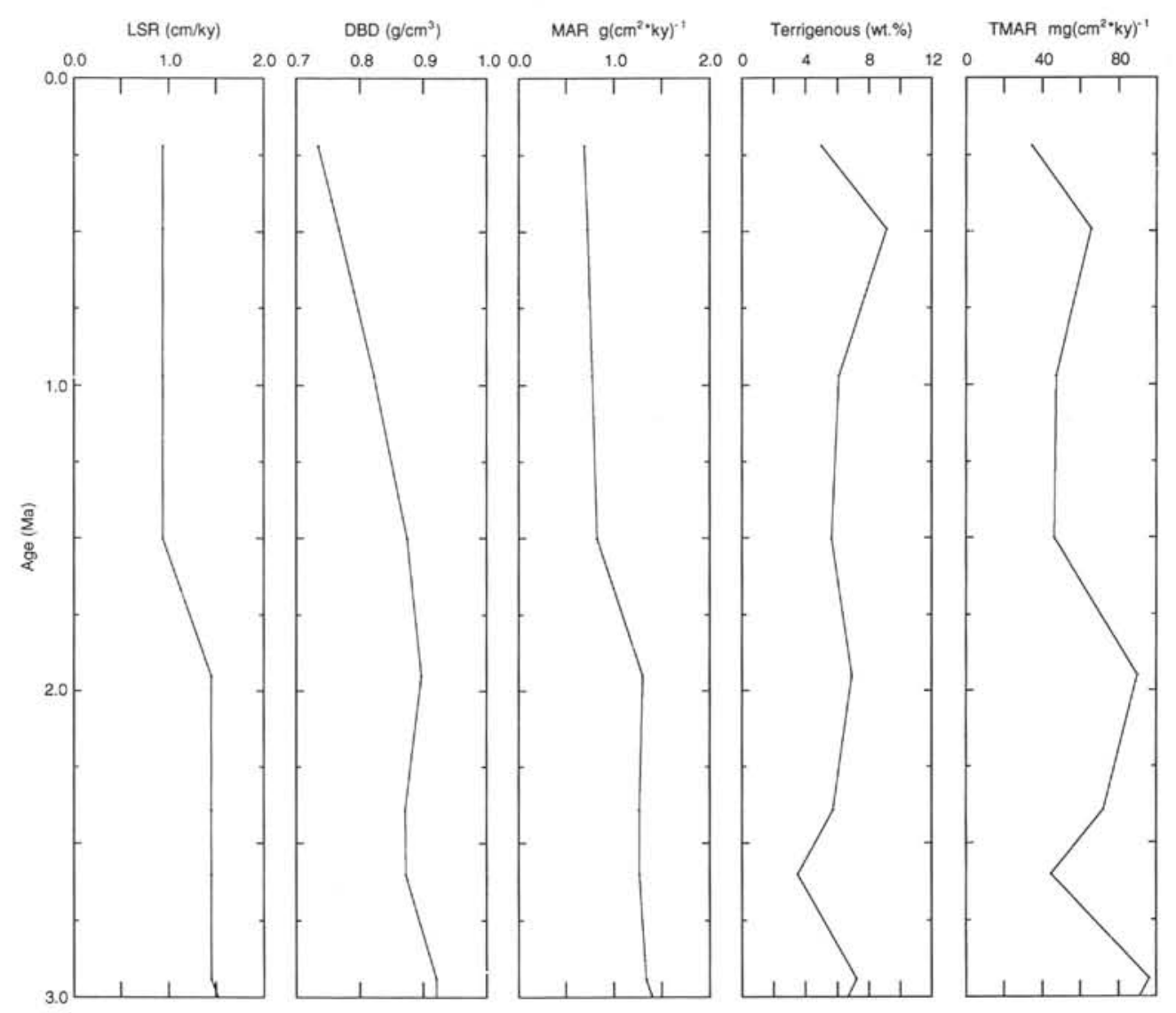

Figure 5. Summary plots of sedimentologic data and mass accumulation rates vs. age (0-3 Ma) in Hole 803D (Ontong Java Plateau). Data are from Krissek and Janecek (1993). DBD = dry bulk density.

A number of recent biological and chemical oceanographic studies have highlighted the potential role of iron in limiting phytoplankton primary production in the northern and central Pacific (DiTullio and Laws, 1991; Martin and Fitzwater, 1988). These studies suggest that temporal fluxes of particulate iron from continental sources may play an important role in phytoplankton bloom dynamics in the open ocean. Thus, an improved understanding of the export of mineral dust from Asian source regions and their accumulation in the sediments of the Pacific Basin may provide clues to understanding long-term carbon flux variations in the northern and central Pacific. This can only be accomplished by attempting to separate and quantify the relative contributions of volcanic and mineral dust sources of atmospheric input to the ocean (see Olivarez et al., 1991; Nakai et al., 1993; Rea, 1994), and also quantify the various contributions to the biogenous flux (measure the percentages of opal and organic carbon in the sediment, in addition to percentage of carbonate).

The stratigraphic positions of identified ash horizons in Core V21146 may provide interesting comparisons with magnetic susceptibility records from this site (John King, URI, personal communication) and with the combined magnetic susceptibility records and identified ash layers at Hole 810C, DSDP Site 577, and possibly at Hole 880A. Rock magnetic measurements of sediments from Core V21-146 (northern Shatsky Rise), DSDP Site 577, and Hole 810C (southern Shatsky Rise; Doh, 1987; Polgreen et al., 1993), and Hole 880A (Takuyo-Daisan Guyot; Rack, Lawyer, and Gee, this volume), form a roughly east to west transect along a N-S trending arc towards Pliocene to Holocene sources of arc volcanism; these sites also extend from the northern boundary of the Pacific Subtropical Gyre toward the region of increased hemipelagic sediment processes along its western boundary (e.g., west of the Kuroshio Current; southeast of
Japan). The combined use of sedimentological and geochemical tools combined with measurements of rock magnetic properties correlated to ash layers may provide a significantly improved stratigraphic framework for this region.

\section{Piston Core KK75-02}

Piston Core KK75-02 was collected from deep water to the east of the Hess Rise (Table 1 and Fig. 1). The predominant sedimentary components of Core KK75-02 are terrigenous clay, radiolarians, and diatoms, with subordinate amounts of quartz, sponge spicules, and manganese micronodules. The stratigraphic control for this core was provided by paleomagnetic reversal stratigraphy and radiolarian extinction levels (Janecek, 1983; Janecek and Rea, 1984, 1985; Rea et al., 1985).

A summary of the weight percentages and mass accumulation rates of principal sedimentary components (from the seafloor to 0.6 $\mathrm{Ma}$ ) is shown in Figure 17 (data from Janecek, 1983). The weight percentage of noneolian material was determined by subtracting the weight percentage of eolian material from $100 \%$; no further quantitative breakdown of sedimentary components is presently available for this core. As noted by Janecek and Rea (1984), there are several relative maxima in eolian accumulation, with reduced rates of accumulation in two intervals centered at $\sim 0.55$ and $\sim 0.12 \mathrm{Ma}$, respectively (also see Rea, 1994).

\section{Links Between Continental and Marine Eolian Records}

A large amount of effort has been put into dating and understanding the climatic significance of the widespread loess and soil deposits of central China. These studies have focused on establishing 


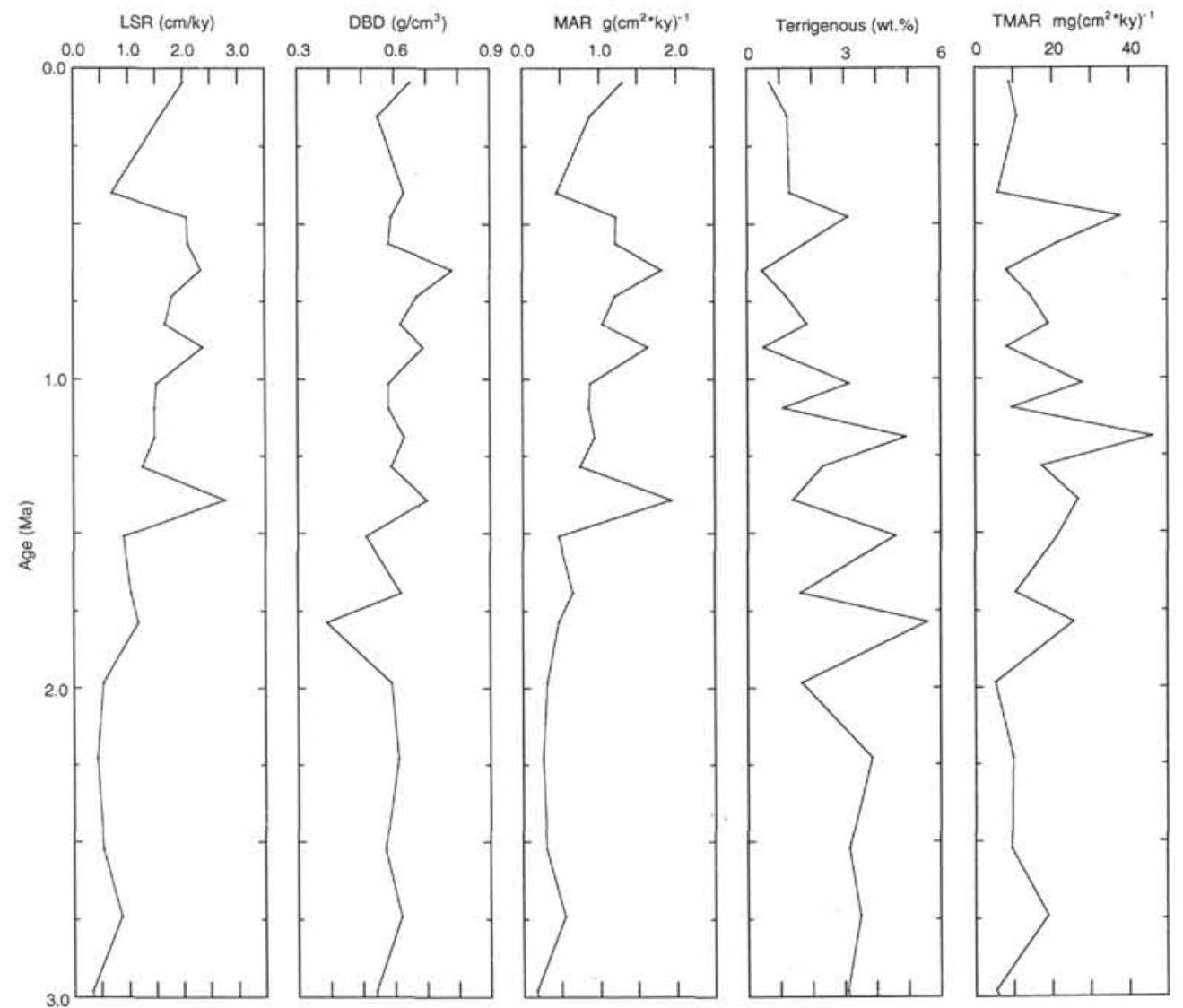

Figure 6. Summary plots of sedimentologic data and mass accumulation rates vs. age (0-3 Ma) in Hole 848B (eastern equatorial Pacific). Data are from Hovan (1995).

the magnetostratigraphy at the various loess localities (Luochuan, Lanzhou, Xifeng, Baoji, etc.) and on understanding the magnetic susceptibility signal, which varies significantly between loess and soil horizons in these sequences (Ding et al., 1993; Heller and Liu, 1982, 1984, 1986; Heller et al., 1991, 1994; Kukla, 1987; Kukla and An, 1989; Kukla et al., 1988, 1990; Liu et al., 1988a, 1988b; Rutter et al., 1990, 1991).

The fluctuations in magnetic susceptibility have been attributed to (1) changes in the atmospheric transport and accumulation of finegrained magnetite, (2) the degree of pedogenesis in different loess or soil horizons, and/or (3) other environmental causes (Evans and Heller, 1994; Eyre and Shaw, 1994; Kukla et al., 1988, 1990; Liu et al., 1992, 1993; Maher and Thompson, 1991) which are linked to fluctuations in aridity, rainfall, temperature and climate over the past $2.5 \mathrm{Ma}$ (An et al., 1991; Ding et al., 1992; Liu et al., 1989; among many others).

Attempts to correlate the magnetic susceptibility record of the loess sequences with the marine oxygen isotope record have met with varying degrees of success, with best results coming from sequences of Brunhes age (Heller and Liu, 1982, 1986; Hovan et al., 1989, 1991; Kukla et al., 1990). At present, the marine eolian record from Core V21-146 (Fig. 16B) is the only one that has been used to provide a direct link between the China loess sequences and mineral fluxes to the open Pacific Ocean.

Figure 18 provides a visual comparison of the weight percentages of mineral components and the mineral accumulation rates from the three northwest Pacific eolian sites discussed in this study (Hole 810C, Core V21-146, and Core KK75-02). Also shown is the magnetic susceptibility record of loess and soil horizons at the Xifeng I locality in Central China (data from Kukla et al., 1990), where high susceptibility values correspond to soil horizons and low susceptibility values correspond to loess beds.
The point of this visual comparison is to suggest that improved correlations between marine eolian records and the Chinese loess sequences are possible for extended stratigraphic intervals, with further improvements to the existing age models and correlations among marine sites with available mineral data. The long high-resolution record from Hole $810 \mathrm{C}$, at present, provides the best opportunity to accomplish these types of land-marine correlations for the older $(>0.5$ Ma) portions of the loess record (Rack and Janecek, unpubl. data).

\section{SUMMARY AND CONCLUSIONS}

This paper has presented the integrated results of quantitative sedimentologic and biostratigraphic studies at Sites 871, 872, and 873 in the Marshall Islands, in Hole 880A on Takuyo-Daisan Guyot, and in Hole $810 \mathrm{C}$ on Shatsky Rise for the late Pliocene to Quaternary. Mass accumulation rates of different sedimentary components have been calculated at each site to compare biogenic and mineral fluxes across a wide geographic region at intermediate and deeper water depths.

Published results from mineral dust studies at additional ODP, DSDP, and core sites located within or near the boundaries of the Pacific Subtropical Gyre have been used to provide regional comparisons among several high-quality eolian records. Additional discussions have addressed the present state of research aimed at understanding the linkages between continental records of paleoclimate from central China and marine eolian records located downstream, beneath the Pacific Ocean.

Based on observed increases in the weight percentage and accumulation rate of lithogenic sediments (terrigenous and volcanic grains), and age estimates from nannofossil stratigraphy, we have tentatively identified the presence of two widespread marker tephra of late Quaternary age in Hole $880 \mathrm{~A}$. These two ashes, which have been identified 

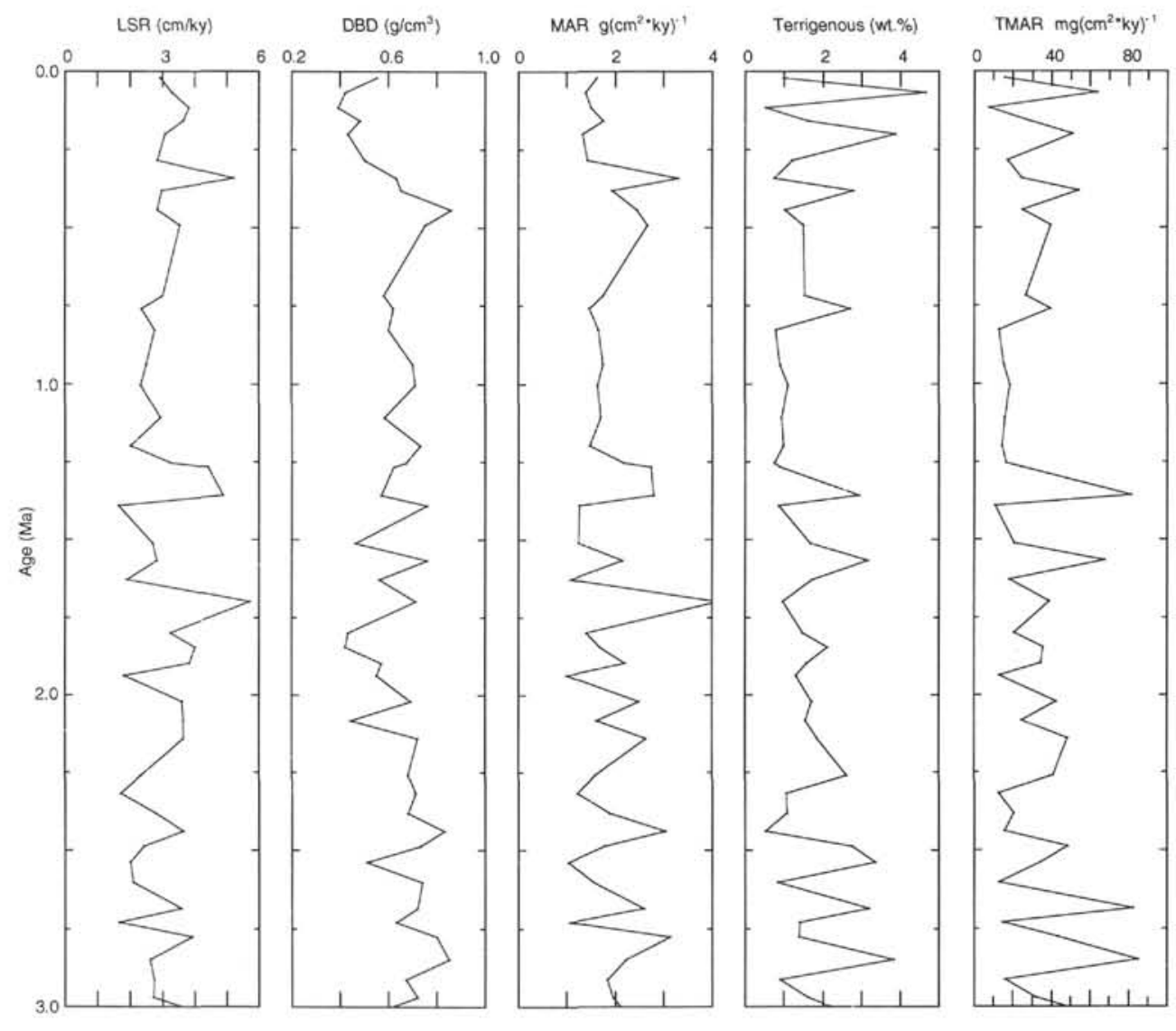

Figure 7. Summary plots of sedimentologic data and mass accumulation rates vs. age (0-3 Ma) in Hole 849B (eastern equatorial Pacific). Data are from Hovan (1995).

on land and in deep-sea sediments around Japan (Machida and Arai, 1983), are identified in Hole $880 \mathrm{~A}$ as the Aira-Tn (AT) ash at $\sim 0.5-0.6$ mbsf, and the Aso- 4 ash at $\sim 1.6-1.7$ mbsf.

The sedimentologic results from Hole $810 \mathrm{C}$ provide a high-resolution record of biogenic and lithogenic sediment accumulation from a locality at intermediate water depth on Shatsky Rise. The record exhibits clear evidence of cyclicity in the character of both carbonate and eolian weight percentage fluctuations, with higher frequency fluctuations for the late Pliocene changing to longer period undulations for the Quaternary.

The combined use of quantitative nannofossil stratigraphic studies, with sedimentologic studies, and the systematic identification of ash (tephra) and pumice layers at sites in the northwest Pacific should improve our understanding of the timing and significance of paleoclimatic and paleoceanographic events in this region. Additional emphasis on oxygen isotope determinations and the use of orbital tuning strategies at these sites will help to improve the stratigraphic resolution.

Improved correlations between marine eolian records, such as the records at Hole $810 \mathrm{C}$ and Core V21-146, and the classic sections of Chinese loess, should make possible higher resolution comparisons than were previously available, especially for older stratigraphic intervals, with further improvements to the age models and through the use of astronomic tuning of the records from these sites.

Fluctuations in mass accumulation rates and terrigenous mineral fluxes seem to be generally coherent between sites in the Marshall Islands, but the low resolution of the data and the presence of currentinfluenced reworking of sediments in some intervals prevent detailed correlations between sites. Significant increases in both MARs and TMARs are observed for the intervals from $>1.7$ to $1.5 \mathrm{Ma}$ and from 1.2 to $1.0 \mathrm{Ma}$ in the records from Limalok and Lo-En guyots (Holes
$871 \mathrm{~A}$ and $872 \mathrm{~A}$ ), and possibly at $\sim 0.4 \mathrm{Ma}$ at Hole $871 \mathrm{~A}$. Hole $873 \mathrm{~B}$ shows a broad increase in TMAR from $\sim 3.0$ to $\sim 1.2 \mathrm{Ma}$, with erosion caused by possible current activity around the summit of Wodejebato Guyot limiting the accumulation of younger sediments. Distinctive fluctuations in nannofloral assemblages are associated with temporal changes in both carbonate and mineral fluxes; these comparisons may provide a linkage between long-term proxy records of paleoclimatic conditions in the western tropical North Pacific.

Quantitative measures of nannofloral abundance fluctuations, both within specific nannofossil groups and among individual species, can be useful for constraining ecologic and oceanographic interpretations for these ODP sites. Major changes in the composition of Pleistocene nannofloras appear to be coeval on a regional basis, across a wide latitudinal range within the subtropical to equatorial belts (Raffi and Flores, 1995; Erba, this volume). However, the nannofossil records from Sites $871,872,873$, and 880 indicate that some taxa were locally and temporarily influenced by the specific oceanographic conditions around these guyots. Future investigations of the distribution of specific taxa, such as the smallest specimens of Gephyrocapsa (2-2.5 $\mu \mathrm{m})$ and Florisphaera profunda, may help in separating global from local or regional effects.

The lack of adequate late Pliocene to Quaternary mineral flux records from Ontong Java Plateau prevents, at present, the effective development of a north-south latitudinal transect of sites across the equator in the western Pacific. The timing of observed fluctuations in sedimentation rates at Hole 806B on Ontong Java Plateau (Berger et al., 1994) suggests that comparisons between the Ontong Java sites and data from the pelagic caps of Leg 144 guyots could lead to an improved understanding of intermediate-water-depth ocean circulation patterns and the geochemical variability of paleowater masses in the western equatorial to tropical Pacific Ocean. 
Improvements in the sampling resolution of eastern equatorial Pacific mineral dust records, their combination with measurements of the flux of other sedimentary components (e.g., \%carbonate, \%opal, \%organic carbon), and the use of near-continuous proxy records (GRAPE bulk density and magnetic susceptibility data) from these cores may significantly improve our understanding of past changes in atmospheric and oceanic conditions in the equatorial Pacific (see Farrell et al., 1995; Pisias et al., 1995). Additional studies on transects of piston cores along $110^{\circ} \mathrm{W}$ longitude (Snoeckx and Rea, 1994) and $135^{\circ} \mathrm{W}$ longitude (Murray et al., 1993) should improve the spatial resolution of paleoclimatic and paleoceanographic proxy records of variability across the equatorial Pacific, and will allow for more rigorous comparisons with the existing records from Core RC11-210.

\section{ACKNOWLEDGMENTS}

The authors thank the reviewers of this synthesis paper, David Rea, Steven Hovan, and John King, whose comments helped to significantly improve the final version. We also thank the participants of Legs 132 and 144 for their individual contributions to this synthesis. F. Rack's contribution to this research was supported by a postdoctoral fellowship from the Natural Sciences and Engineering Research Council of Canada (NSERC), through the Canadian Joint Global Ocean Flux Study (CJGOFS). F. Rack would also like to thank Larry Mayer and the Ocean Mapping Group for their ongoing support of this research.

\section{REFERENCES*}

An, Z.S., Kukla, G., Porter, S.C., and Xiao, J.L., 1991. Late Quaternary dust flow on the Chinese Loess Plateau. Catena, 18:125-132.

Arimoto, R., Duce, R.A., Ray, B.J., and Unni, C.K., 1985. Atmospheric trace elements at Enewetak Atoll: 2. Transport to the ocean by wet and dry deposition. J. Geophys. Res., 90:2391-2408.

Berger, W.H., Yasuda, M.K., Bickert, T., Wefer, G., and Takayama, T., 1994. Quaternary time scale for the Ontong Java Plateau: Milankovitch template for Ocean Drilling Program Site 806. Geology, 22:463-467.

Betzer, P.R., Carder, K.L., Duce, R.A., Merrill, J.T., Tindale, N.W., Uematsu, M., Costello, D.K., Young, R.W., Feeley, R.A., Breland, J.A., Bernstein, R.E., and Greco, A.M., 1988. Long-range transport of giant mineral aerosol particles. Nature, 336:568-571.

Blank, M., Leinen, M., and Prospero, J.M., 1985. Major Asian eolian inputs indicated by the mineralogy of aerosols and sediments in the western North Pacific. Nature, 314:84-86.

Castradori, D., 1993. Calcareous nannofossil biostratigraphy and biochronology in eastern Mediterranean deep-sea cores. Riv. Ital. Paleontol. Stratigr., 99:107-126.

Chuey, J.M., Rea, D.K., and Pisias, N.G., 1987. Late Pleistocene paleoclimatology of the central equatorial Pacific: a quantitative record of eolian and carbonate deposition. Quat. Res., 28:323-339.

Clemens, S.C., and Prell, W.L., 1990. Late Pleistocene variability of Arabian Sea summer monsoon winds and continental aridity: eolian records from the lithogenic component of deep-sea sediments. Paleoceanography, 5:109-145.

Ding, Z.L., Rutter, N., Han, J.T., and Liu, T.S., 1992. A coupled environmental system formed at about 2.5 Ma in East Asia. Palaeogeogr., Palaeoclimatol., Palaeoecol., 94:223-242.

Ding, Z.L., Rutter, N., and Liu, T.S., 1993. Pedostratigraphy of Chinese loess deposits and climatic cycles in the last 2.5 Myr. Catena, 20:73-91.

DiTullio, G.R., and Laws, E.A., 1991. Impact of an atmospheric-oceanic disturbance on phytoplankton community dynamics in the North Pacific Central Gyre. Deep-Sea Res. Part A, 38:1305-1329.

\footnotetext{
-Abbreviations for names of organizations and publications in ODP reference lists follow the style given in Chemical Abstracts Service Source Index (published by American Chemical Society).
}

Doh, S.-J., 1987. Rock-magnetic and paleomagnetic studies of marine sediments from the central and western North Pacific: stratigraphic and paleoceanographic implications [Ph.D. dissert.]. Univ. of Rhode Island, Kingston.

Duce, R.A., Arimoto, R., Ray, B.J., Unni, C.K., and Harder, P.J., 1983. Atmospheric trace elements at Enewetak Atoll: 1. Concentrations, sources, and temporal variability. J. Geophys. Res., 88:5321-5342.

Duce, R.A., Liss, P.S., Merrill, J.T., Atlas, L.L., Buat-Menard, P., Hicks, B.B., Miller, J.M., Prospero, J.M., Arimoto, R., Church, T.M., Ellis, W., Galloway, J.N., Hansen, L., Jickells, T.D., Knap, A.H., Reinhardt, K.H., Schneider, B., Soudine, A., Tokos, J.J., Tsunogai, S., Wollast, R., and Zhou, M., 1991. The atmospheric input of trace species to the world ocean. Global Biogeochem. Cycles, 5:193-259.

Duce, R.A., Unni, C.K., Ray, B.J., Prospero, J.M., and Merrill, J.T., 1980. Long-range atmospheric transport of soil dust from asia to the Tropical North Pacific: temporal variability. Science, 209:1522-1524.

Evans, M.E., and Heller, F., 1994. Magnetic enhancement and palaeoclimate: study of a loess/palaeosol couplet across the Loess Plateau of China. Geophys. J. Int., 117:257-264.

Eyre, J.K., and Shaw, J., 1994. Magnetic enhancement of Chinese loess-the role of $\mathrm{Fe}_{2} \mathrm{O}_{3}$ ? Geophys. J. Int., 117:265-271.

Farrell, J.W., Raffi, I., Janecek, T.R., Murray, D.W., Levitan, M., Dadey, K.A., Emeis, K.-C., Lyle, M., Flores, J.-A., and Hovan, S., 1995. Late Neogene sedimentation patterns in the eastern equatorial Pacific. In Pisias, N.G., Mayer, L.A., Janecek, T.R., Palmer-Julson, A., and van Andel, T. H. (Eds.), Proc. ODP, Sci. Results, 138: College Station, TX (Ocean Drilling Program), 717-756.

Furuta, T., Fujioka, K., and Arai, F., 1986. Widespread submarine tephra around. Japan, petrographic and chemical property. Mar. Geol., 72:125146.

Heller, F., and Liu, T.S., 1982. Magnetostratigraphical dating of loess deposits in China. Nature, 300:431-433.

, 1984. Magnetism of chinese loess deposits. Geophys. J. R. Astron. Soc., 77:125-141.

, 1986. Palaeoclimatic and sedimentary history from magnetic susceptibility of loess in China. Geophys. Res. Lett., 13:1169-1172.

Heller, F., Liu, X.M., Liu, T.S., and Xu, T.C., 1991. Magnetic susceptibility of loess in China. Earth Planet. Sci. Lett., 103:301-310.

Heller, F., Shen, C.D., Beer, J., Liu, X.M., Liu, T.S., Bronger, A., Suter, M., and Bonani, G., 1993. Quantitative estimates of pedogenic ferromagnetic mineral formation in Chinese loess and paleoclimatic implications. Earth Planet. Sci. Lett., 114:385-390.

Hovan, S.A., 1995. Late Cenozoic atmospheric circulation intensity and climatic history recorded by eolian deposition in the eastern equatorial Pacific, Leg 138. In Pisias, N.G., Mayer, L.A., Janecek, T.R., Palmer-Julson, A., and van Andel, T.H. (Eds.), Proc. ODP, Sci. Results, 138: College Station, TX (Ocean Drilling Program), 615-625.

Hovan, S.A., Rea, D.K., and Pisias, N.G., 1991. Late Pleistocene continental climate and oceanic variability recorded in northwest Pacific sediments. Paleoceanography, 6:349-370.

Hovan, S.A., Rea, D.K., Pisias, N.G., and Shackleton, N.J., 1989. A direct link between the China loess and marine $\delta^{18} \mathrm{O}$ records: aeolian flux to the North Pacific. Nature, 340:296-298.

Janecek, T.R., 1985. Eolian sedimentation in the northwest Pacific Ocean: a preliminary examination of the data from Deep Sea Drilling Project Sites 576 and 578. In Heath, G.R., Burckle, L.H., et al., Init. Repts. DSDP, 86: Washington (U.S. Govt. Printing Office), 589-603.

-1983 . The history of eolian sedimentation and atmospheric circulation during the late Cenozoic [Ph.D. dissert.]. Univ. of Michigan, Ann Arbor.

Janecek, T.R., and Rea, D.K., 1983. Eolian deposition in the northeast Pacific Ocean: Cenozoic history of atmospheric circulation. Geol. Soc. Am. Bull., 94:730-738.

, 1984. Pleistocene fluctuations in Northern Hemisphere tradewinds and westerlies. In Berger, A.L., Imbrie, J., Hays, J., Kukla, G., and Saltzman, B. (Eds.), Milankovitch and Climate (Pt. 1): Dordrecht (D. Reidel), 331-347.

- 1985. Quaternary fluctuation in the Northern Hemisphere trade winds and westerlies. Quat. Res., 24:150-163.

Kamata, H., 1989. Volcanic and structural history of the Hohi volcanic zone, central Kyushu, Japan. Bull. Volcanol., 51:315-332.

Kamata, H., and Kodama, K., 1994. Tectonics of an arc-arc junction: an example from Kyushu Island at the junction of the Southwest Japan Arc and the Ryukyu Arc. Tectonophysics, 233:69-81. 
Kennett, J.P., McBirney, A.R., and Thunnell, R.C., 1977. Episodes of Cenozoic volcanism in the Circum-Pacific region. J. Volcanol. Geotherm. Res., 2:145-163.

Kennett, J.P., and Thunell, R.C., 1975. Global increase in Quaternary explosive volcanism. Science, 187:497-503.

Krissek, L.A., and Janecek, T.R., 1993. Eolian deposition on the Ontong Java Plateau since the Oligocene: unmixing a record of multiple dust sources. In Berger, W.H., Kroenke, L.W., Mayer, L.A., et al., Proc. ODP, Sci. Results, 130: College Station, TX (Ocean Drilling Program), 471-490.

Kukla, G., 1987. Loess stratigraphy in central China. Quat. Sci. Rev., 6:191-219.

Kukla, G., and An, Z., 1989. Loess stratigraphy in central China. Palaeogeogr, Palaeoclimatol., Palaeoecol., 72:203-225.

Kukla, G., An, Z.S., Melice, J.L., Gavin, J., and Xia, J.L., 1990. Magnetic susceptibility record of Chinese loess. Trans. R. Soc. Edinburgh: Earth Sci., 81:263-288.

Kukla, G., Heller, F., Liu, X.M., Xu, T.C., Liu, T.S., and An, Z.S., 1988. Pleistocene climates in China dated by magnetic susceptibility. Geology, 16:811-814.

Leinen, M., 1989. The late Quaternary record of atmospheric transport to the northwest Pacific from Asia. In Leinen, M., and Sarnthein, M. (Eds.), Paleoclimatology and Paleometeorology: Modern and Past Patterns of Global Atmospheric Transport. New York: (Kluwer Acad. Publ.), 693-732.

1985. Quartz content of northwest Pacific Hole 576 A and implications for Cenozoic eolian transport. In Heath, G.R., Burckle, L.H., et al., Init. Repts. DSDP, 86: Washington (U.S. Govt. Printing Office), 581-588.

Leinen, M., and Heath, G.R., 1981. Sedimentary indicators of atmospheric circulation in the Northern Hemisphere during the Cenozoic. Palaeogeogr., Palaeoclimatol., Palaeoecol., 36:1-21.

Liu, X.M., Liu, T.S., Xu, T.C., Liu, C., and Chen, M.Y., 1988a. The Chinese loess at Xifeng, I. The primary study on magnetostratigraphy of a loess profile in Xifeng area, Gansu province. Geophys. J., 92:345-348.

Liu, X.M., Shaw, J., Liu, T.S., and Heller, F., 1993. Magnetic susceptibility of the Chinese loess-palaeosol sequence: environmental change and pedogenesis. J. Geol. Soc. London, 150:583-588.

Liu, X.M., Shaw, J., Liu, T.S., Heller, F., and Yuan, B.Y., 1992. Magnetic mineralogy of Chinese loess and its significance. Geophys. J. Int., 108:301-308.

Liu, X.M., Xu, T.C., and Liu, T.S., 1988b. The Chinese loess in Xifeng, II. A study of anisotropy of magnetic susceptibility of loess from Xifeng. Geophys. J., 92:349-353.

Machida, H., and Arai, F., 1976. The widespread tephra-the Aira-Tn ash. Kagaku, 46:339-347.

- 1978. Akahoya ash-a widespread tephra erupted from the Kikai caldera, southern Kyushu, Japan. Quat. Res. Jpn., 17:143-163. 1983. Extensive ash falls in and around the sea of Japan from large late Quatemary eruptions. J. Volcanol. Geotherm. Res., 18:151-164.

, 1988. A review of late Quaternary deep-sea tephras around Japan. Quat. Res. (Tokyo), 26:227-242.

Maher, B.A., and Thompson, R., 1991. Mineral magnetic record of the Chinese loess and paleosols. Geology, 19:3-6.

Martin, J.H., and Fitzwater, S.E., 1988. Iron deficiency limits phytoplankton growth in the north-east Pacific subarctic. Nature, 308:621-624.

Merrill, J.T., Uematsu, M., and Bleck, R., 1989. Meteorological analysis of long range transport of mineral aerosols over the North Pacific. J. Geophys. Res., 94:8584-8598.

Murray, R.W., and Leinen, M., 1993. Chemical transport to the seafloor of the equatorial Pacific Ocean across a latitudinal transect at $135^{\circ} \mathrm{W}$ : tracking sedimentary major, trace, and rare earth element fluxes at the equator and the Intertropical Convergence Zone. Geochim. Cosmochim. Acta., 57:4141-4163.

Murray, R.W., Leinen, M., and Isern, A.R., 1993. Biogenic flux of Al to sediment in the central equatorial Pacific Ocean: evidence for increased productivity during glacial periods. Paleoceanography, 8:651-670.

Nakai, S., Halliday, A.N., and Rea, D.K., 1993. Provenance of dust in the Pacific Ocean. Earth Planet. Sci. Lett., 119:143-157.

Natland, J.H., 1993. Volcanic ash and pumice at Shatsky Rise: sources, mechanisms of transport, and bearing on atmospheric circulation. In Natland, J.H., Storms, M.A., et al., Proc. ODP, Sci. Results, 132: College Station, TX (Ocean Drilling Program), 57-66.

Olivarez, A.M., Owen, R.M., and Rea, D.K., 1991. Geochemistry of eolian dust in Pacific pelagic sediments: implications for paleoclimactic interpretations. Geochim. Cosmochim. Acta, 55:2147-2158.

Phillips, F.M., Zreda, M.G., Ku, T.-L., Luo, S., Huange, Q., Elmore, D., Kubik, P.W., and Sharma, P., 1993. ${ }^{230} \mathrm{Th} /{ }^{234} \mathrm{U}$ and ${ }^{36} \mathrm{Cl}$ dating of evaporite deposits from the western Qaidam Basin, China: implications for glacial-period dust export from Central Asia. Geol. Soc. Am. Bull., 105:1606-1616.

Pisias, N.G., Mayer, L.A., and Mix, A.C., 1995. Paleoceanography of the eastern equatorial Pacific during the Neogene: synthesis of Leg 138 drilling results. In Pisias, N.G., Mayer, L.A., Janecek, T.R., Palmer-Julson, A., and van Andel, T.H. (Eds.), Proc. ODP, Sci. Results, 138: College Station, TX (Ocean Drilling Program), 5-21.

Pisias, N.G., and Rea, D.K., 1988. Late Pleistocene paleoclimatology of the central equatorial Pacific: sea surface response to the southeast trade winds. Paleoceanography, 3:21-37.

Polgreen, E.L., Sager, W.W., Rack, F.R., and van Waasbergen, R.J., 1993. Magnetic properties of Pliocene-Pleistocene sediments from Hole 810C, Shatsky Rise, and implications for the origin and correlatability of their magnetic susceptibility variations. In Natland, J.H., Storms, M.A., et al., Proc. ODP, Sci. Results, 132: College Station, TX (Ocean Drilling Program), 37-45.

Premoli Silva, I., Castradori, D., and Spezzaferri, S., 1993. Calcareous nannofossil and planktonic foraminifer biostratigraphy of Hole 810C (Shatsky Rise, northwestem Pacific). In Natland, J.H., Storms, M.A., et al., Proc. ODP, Sci. Results, 132: College Station, TX (Ocean Drilling Program), 15-36.

Premoli Silva, I., Haggerty, J., Rack, F., et al., 1993. Proc. ODP, Init. Repts., 144: College Station, TX (Ocean Drilling Program).

Prospero, J.M., 1981. Arid regions as sources of mineral aerosols in the marine atmosphere. In Pewe, T.L. (Ed.), Desert Dust: Origin, Characteristics, and Effects on Man. Spec. Pap.-Geol. Soc. Am., 186:71-86.

Pye, K., and Zhou, L.-P., 1989. Late Pleistocene and Holocene aeolian dust deposition in North China and the Northwest Pacific Ocean. Palaeogeogr., Palaeoclimatol., Palaeoecol., 73:11-23.

Rack, F.R., Janecek, T.R., Swart, P.K., and Brass, G.W., 1993. Data report: High-resolution carbonate and oxygen isotope data from Site 810: comparison to GRAPE bulk density and magnetic susceptibility data. In Natland, J.H., Storms, M.A., et al., Proc. ODP, Sci. Results, 132: College Station, TX (Ocean Drilling Program), 69-79.

Raffi, I., Backman, J., Rio, D., and Shackleton, N.J., 1993. Plio-Pleistocene nannofossil biostratigraphy and calibration to oxygen isotopes stratigraphies from Deep Sea Drilling Project Site 607 and Ocean Drilling Program Site 677. Paleoceanography, 8:387-408.

Raffi, I., and Flores, J.-A., 1995. Pleistocene through Miocene calcareous nannofossils from eastern equatorial Pacific Ocean (Leg 138). In Pisias, N.G., Mayer, L.A., Janecek, T.R., Palmer-Julson, A., and van Andel, T.H. (Eds.), Proc. ODP, Sci. Results, 138: College Station, TX (Ocean Drilling Program), 233-286.

Rea, D.K., 1990. Aspects of atmospheric circulation: the late Pleistocene $(0-950,000 \mathrm{yr})$ record of eolian deposition in the Pacific Ocean. Palaeogeogr., Palaeoclimatol., Palaeoecol., 78:217-227.

, 1994. The paleoclimatic record provided by eolian deposition in the deep sea-the geologic history of wind. Rev. Geophys., 32:159-195.

Rea, D.K., Basov, I.A., Janecek, T.R., Palmer-Julson, A., et al., 1993. Proc. ODP, Init. Repts., 145: College Station, TX (Ocean Drilling Program).

Rea, D.K., Chambers, L.W., Chuey, J.M., Janecek, T.R., Leinen, M., and Pisias, N.G., 1986. A 420,000-year record of cyclicity in oceanic and atmospheric processes from the eastern equatorial Pacific. Paleoceanography, 1:577-586.

Rea, D.K., and Janecek, T.R., 1981. Mass-accumulation rates of the nonauthigenic inorganic crystalline (eolian) component of deep-sea sediments from the western mid-Pacific Mountains, Deep Sea Drilling Project Site 463. In Theide, J., Vallier, T.L., et al., Init. Repts. DSDP, 62: Washington (U.S. Govt. Printing Office), 653-659.

1982. Late Cenozoic changes in atmospheric circulation deduced from North Pacific eolian sediments. Mar. Geol., 49:149-167.

Rea, D.K., and Leinen, M., 1988. Asian aridity and the zonal westerlies: late Pleistocene and Holocene record of eolian deposition in the Northwest Pacific Ocean. Palaeogeogr, Palaeoclimatol., Palaeoecol., 66:1-8.

Rea, D.K., Leinen, M., and Janecek, T.R., 1985. A geological approach to the long-term history of atmospheric circulation. Science, 227:721-725.

Rea, D.K., Pisias, N.G., and Newberry, T., 1991. Late Pleistocene paleoclimatology of the central equatorial Pacific: flux patterns of biogenic sediments. Paleoceanography, 6:227-244.

Rea, D.K., and Scheidegger, K.F., 1979. Eastern Pacific spreading rate fluctuations and its relation to Pacific area volcanic episodes. J. Volcanol. Geothermal Res., 5:135-148.

Rio, D., 1982. The fossil distribution of coccolithophore genus Gephyrocapsa Kamptner and related Plio-Pleistocene chronostratigraphic problems. In Prell, W.L., Gardner, J.V., et al., Init. Repts. DSDP, 68: Washington (U.S. Govt. Printing Office), 325-343. 
Rio, D., Raffi, I., and Villa, G., 1990. Pliocene-Pleistocene calcareous nannofossil distribution patterns in the Western Mediterranean. In Kastens, K.A., Mascle, J., et al., Proc. ODP, Sci. Results, 107: College Station, TX (Ocean Drilling Program), 513-533.

Rutter, N., Ding, Z.L., Evans, M.E., and Liu, T.S., 1991. Baoji-type pedostratigraphic section, Loess Plateau, North-Central China. Quat. Sci. Rev., 10:1-22.

Rutter, N., Ding, Z.L., Evans, M.E., and Wang, Y.C., 1990. Magnetostratigraphy of the Baoji Loess-Paleosol section in the North-Central China Loess Plateau. Quat. Int., 7/8:97-102.

Sager, W.W., Polgreen, E.L., and Rack, F.R., 1993. Magnetic polarity reversal stratigraphy of Hole $810 \mathrm{C}$, Shatsky Rise, Western Pacific Ocean. In Natland, J.H., Storms, M.A., et al., Proc. ODP, Sci. Results, 132: College Station, TX (Ocean Drilling Program), 47-55.

Sancetta, C., and Silvestri, S., 1986. Pliocene-Pleistocene evolution of the North Pacific ocean-atmosphere system, interpreted from fossil diatoms. Paleoceanography, 1:163-180.

Shackleton, N.J., Crowhurst, S., Hagelberg, T., Pisias, N.G., and Schneider, D.A., 1995. A new late Neogene time scale: application to Leg 138 sites. In Pisias, N.G., Mayer, L.A., Janecek, T.R., Palmer-Julson, A., and van Andel, T.H. (Eds.), Proc. ODP, Sci. Results, 138: College Station, TX (Ocean Drilling Program), 73-101.

Shimizu, S., and Itaya, T., 1993. Plio-Pleistocene arc magmatism controlled by two overlapping subducted plates, central Japan. Tectonophysics, 225:139-154.

Snoeckx, H., and Rea, D.K., 1994. Late Quaternary $\mathrm{CaCO}_{3}$ stratigraphy of the eastern equatorial Pacific. Paleoceanography, 9:341-353.

Storms, M.A., Natland, J.H., et al., 1991. Proc. ODP, Init. Repts., 132: College Station, TX (Ocean Drilling Program).
Takayama, T., 1993. Notes on Neogene calcareous nannofossil biostratigraphy of the Ontong Java Plateau and size variations of Reticulofenestra coccoliths. In Berger, W.H., Kroenke, L.W., Mayer, L.A., et al., Proc. ODP, Sci. Results, 130: College Station, TX (Ocean Drilling Program), 179-229.

Uematsu, M., Duce, R., Nakaya, S., and Tsunogai, S., 1985. Short-term temporal variability of eolian particles in surface waters of the northwestern North Pacific. J. Geophys. Res., 90:1167-1172.

Uematsu, M., Duce, R.A., Prospero, J.M., Chen, L., Merrill, J.T., and McDonald, R.L., 1983. Transport of mineral aerosol from Asia over the North Pacific Ocean. J. Geophys. Res., 88:5343-5352.

Wei, W., 1993. Calibration of upper Pliocene-lower Pleistocene nannofossil events with oxygen isotope stratigraphy. Paleoceanography, 8:85-99.

Windom, H.L., 1976. Lithogenous material in marine sediments. In Riley, J.P., and Chester, R. (Eds.), Chemical Oceanography (Vol. 5): New York (Academic Press), 103-135.

Wyrtki, K., 1974. Sea level and the seasonal fluctuations of the equatorial currents in the Western Pacific Ocean. J. Phys. Oceanogr., 4:91-103.

Zhang, X., An, Z.S., Chen, T., Zhang, G.Y., Arimoto, R., and Ray, B.J., 1994. Late Quaternary records of the atmospheric input of eolian dust to the center of the Chinese Loess Plateau. Quat. Res., 41:35-43.

Date of initial receipt: 1 August 1994

Date of acceptance: 5 December 1994

Ms 144SR-065 
F.R. RACK ET AL.

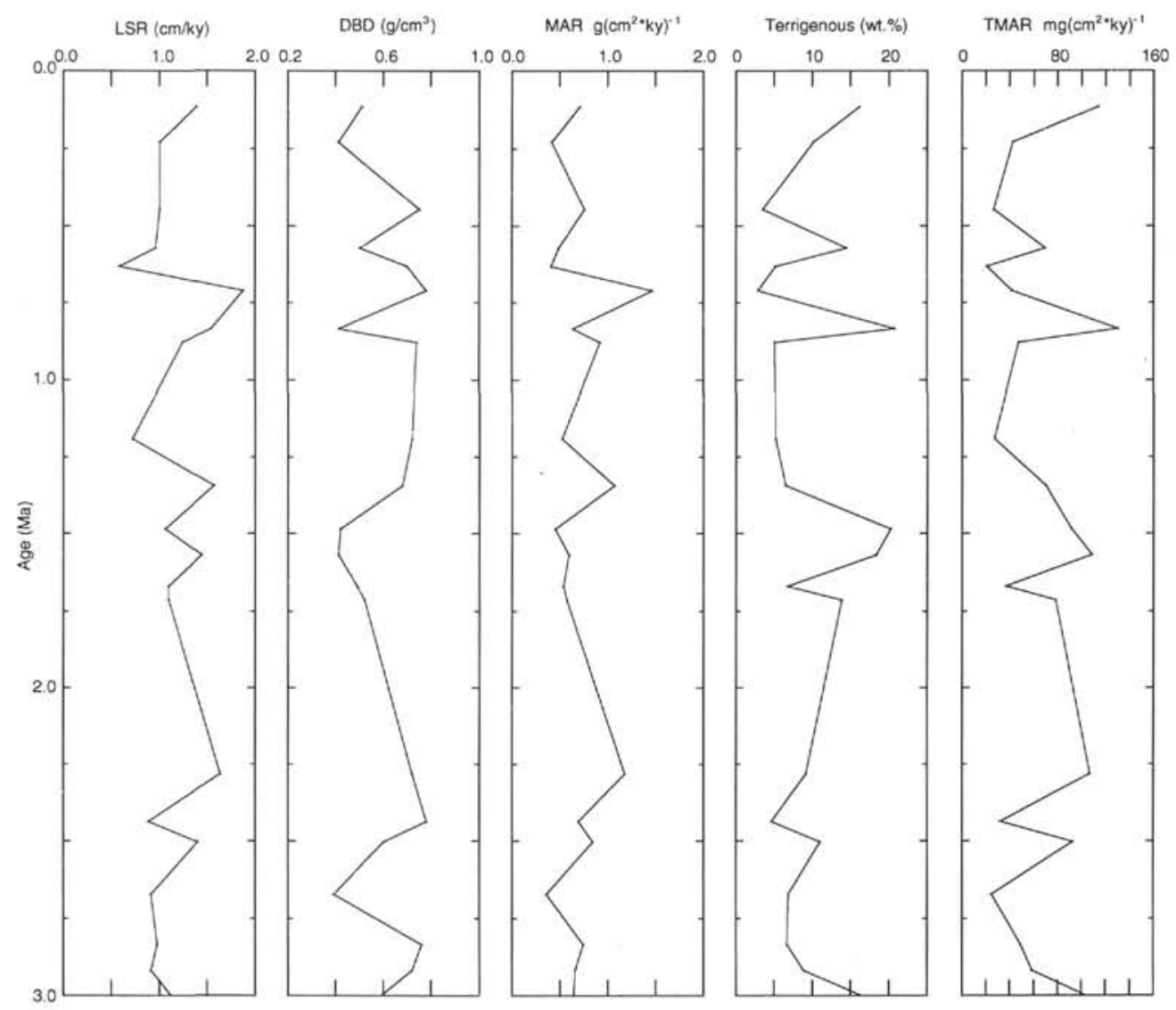

Figure 8. Summary plots of sedimentologic data and mass accumulation rates vs. age (0-3 Ma) in Hole 852B (eastern equatorial Pacific). Data are from Hovan (1995). 


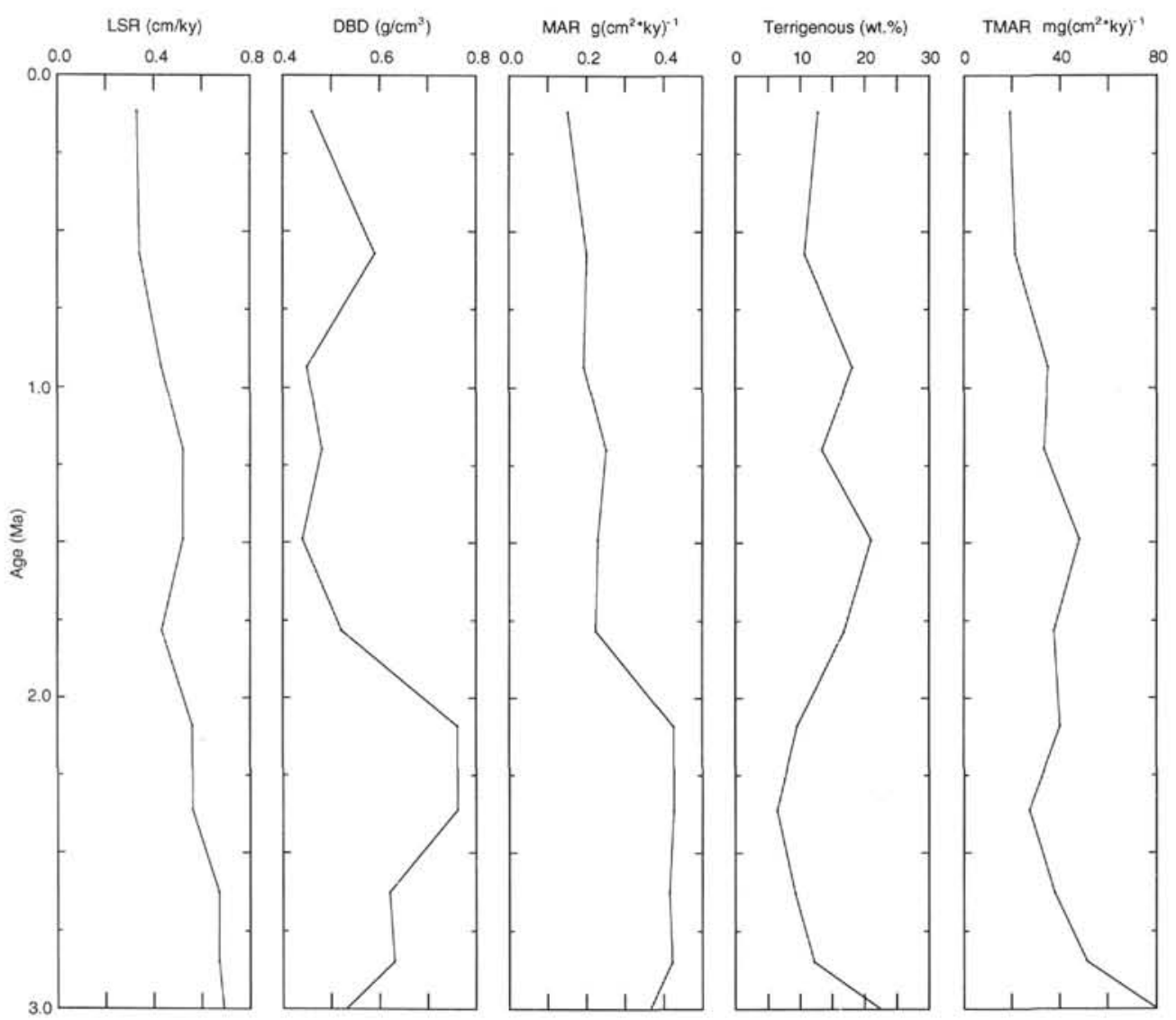

Figure 9. Summary plots of sedimentologic data and mass accumulation rates vs. age (0-3 Ma) in Hole 853B (eastern equatorial Pacific). Data are from Hovan (1995). 
F.R. RACK ET AL.

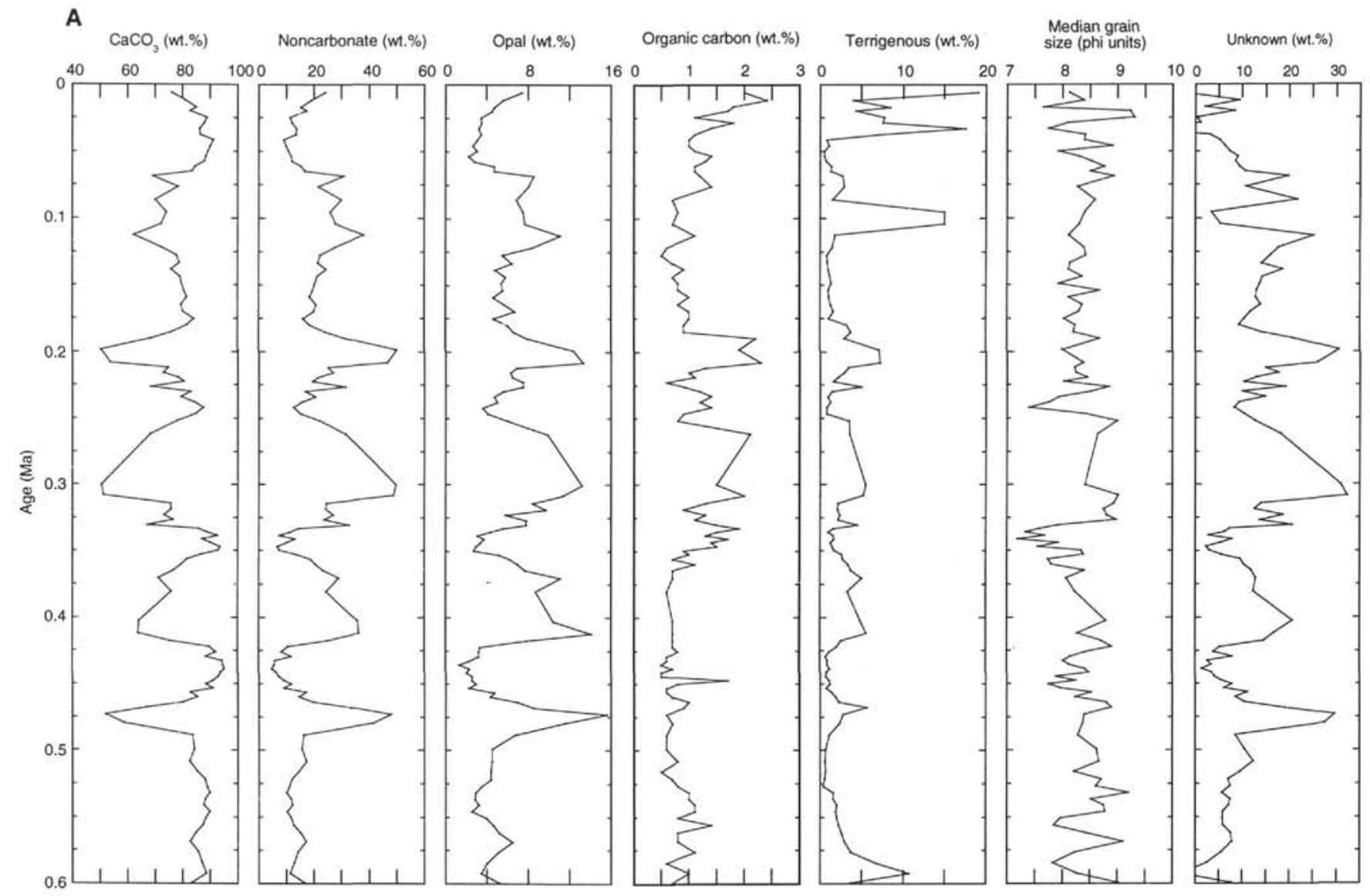

Figure 10. A. Summary plots of sedimentologic data vs. age (0-0.6 Ma) for piston Core RC11-210 (central equatorial Pacific). Data are from Chuey et al. (1987) and Rea et al., (1991). B. Summary plots of mass accumulation rates vs. age (0-0.6 Ma) for piston Core RC11-210. Above about $0.3 \mathrm{Ma}$, there is an inferred change in the source of terrigenous material, from Asian sources below to South American sources above (Chuey et al., 1987; Rea et al., 1991). The percentage of "unknown" corresponds to the weight percentage of noncarbonate material that has not been identified in the total percentage $(100 \%-$ wt $\%$ [carbonate + opal + organic carbon + terrigenous components]). 
SYNTHESIS OF TERRIGENOUS ACCUMULATION RATES

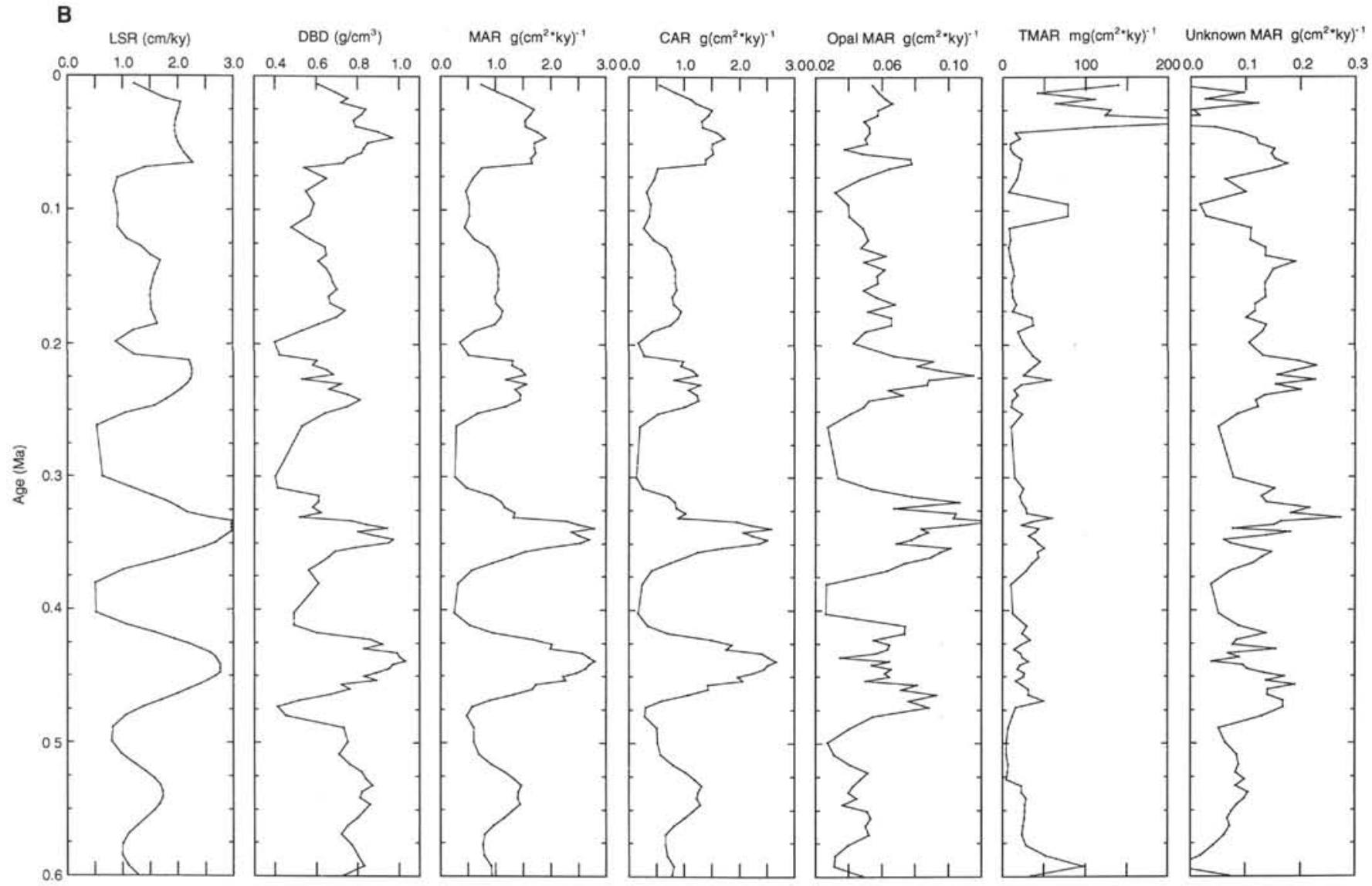

Figure 10 (continued). 
F.R. RACK ET AL.

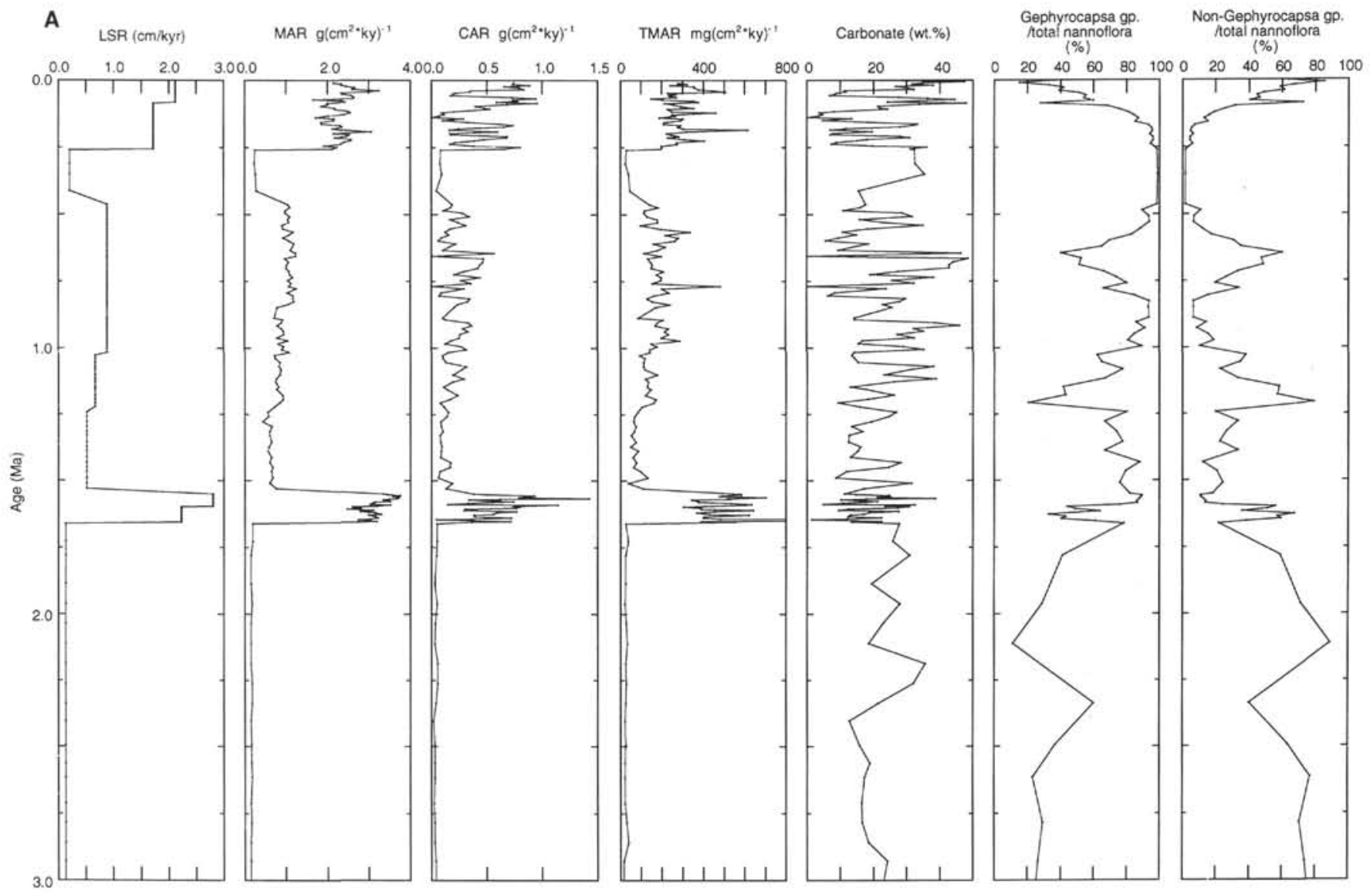

Figure 11. A. Summary plots of sedimentologic data and mass accumulation rates vs. age (0-3 Ma) in Hole 880A (Takuyo-Daisan Guyot). Note that TMAR is given in units of $\mathrm{mg}\left(\mathrm{cm}^{2} \mathrm{k} . \mathrm{y} .\right)^{-1}$. B. Summary plots of quantitative nannofossil biostratigraphy vs. age (Ma) in Hole 880A. Data are from Erba (this volume). 
SYNTHESIS OF TERRIGENOUS ACCUMULATION RATES

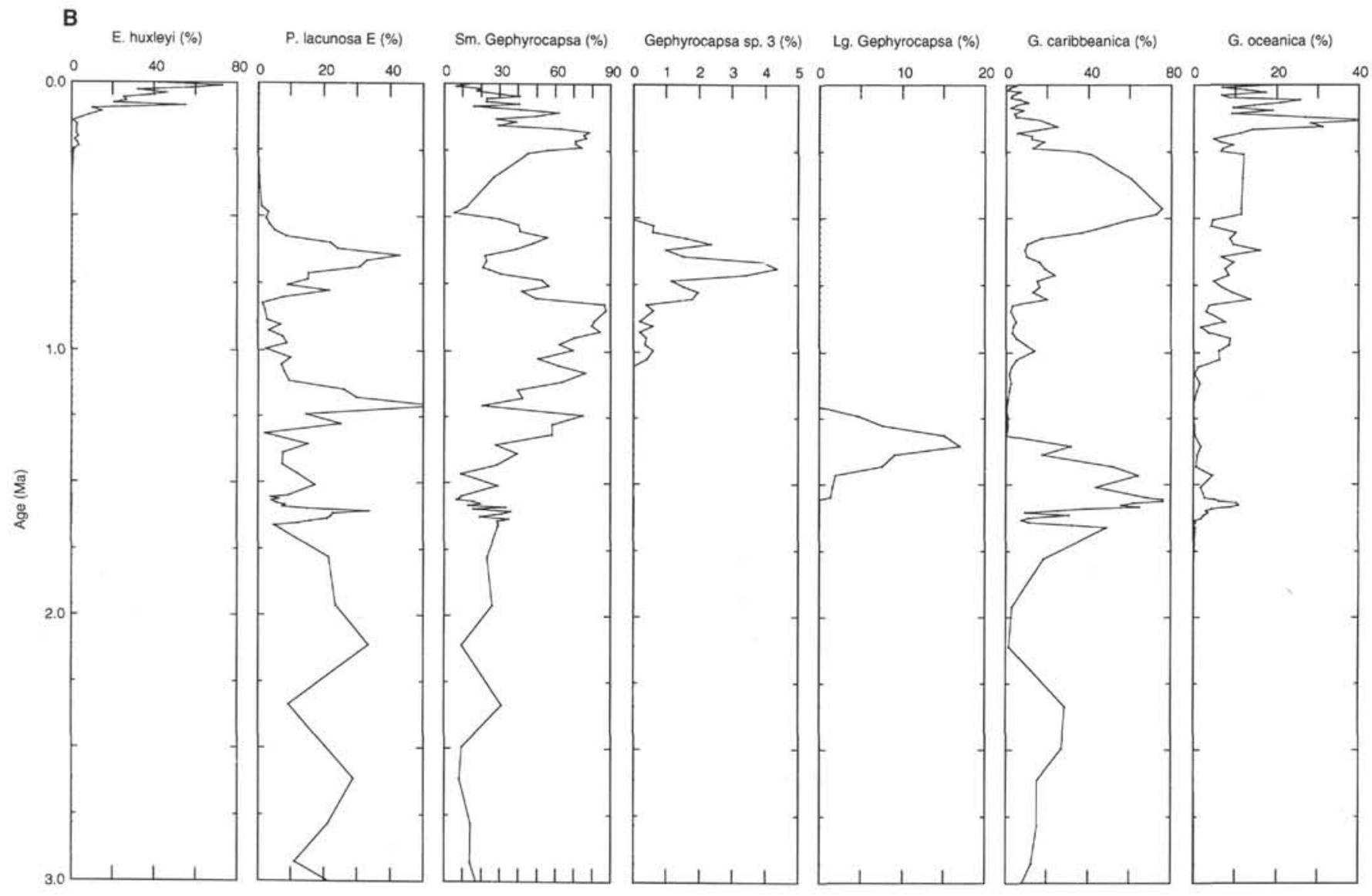

Figure 11 (continued). 


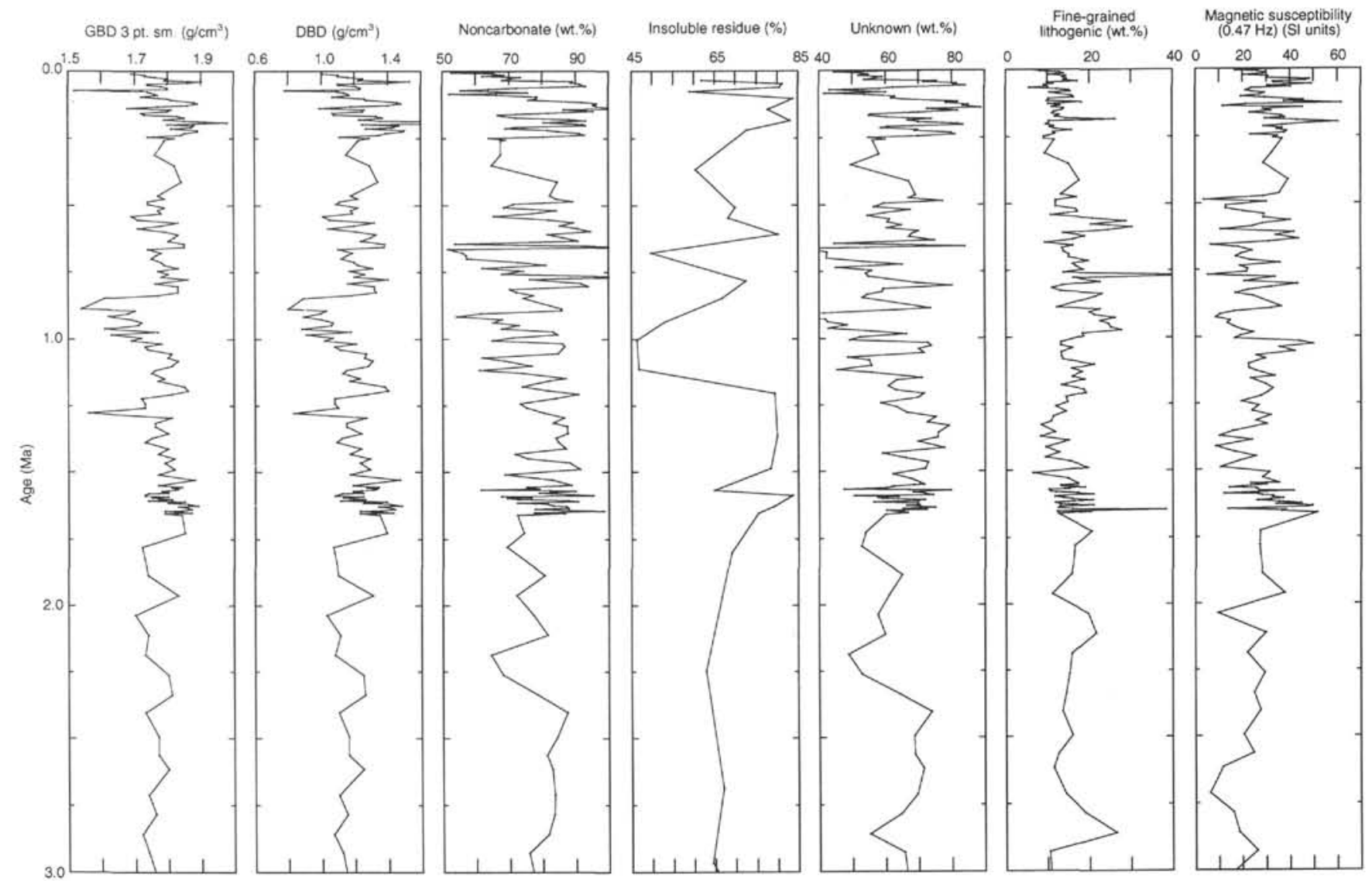

Figure 12. Summary plots of physical properties, sedimentologic data, and low-field magnetic susceptibility vs. age (Ma) in Hole 880A. The percentage of insoluble residue in bulk samples is obtained from data in Fenner (this volume). The percentage of "unknown" material equals the percentage of noncarbonate material minus the fine-grained lithogenic material. Much of the "unknown" material is suspected to be sand-sized volcanic or hemipelagic grains (see Rack, Lawyer, and Gee, this volume). 
SYNTHESIS OF TERRIGENOUS ACCUMULATION RATES

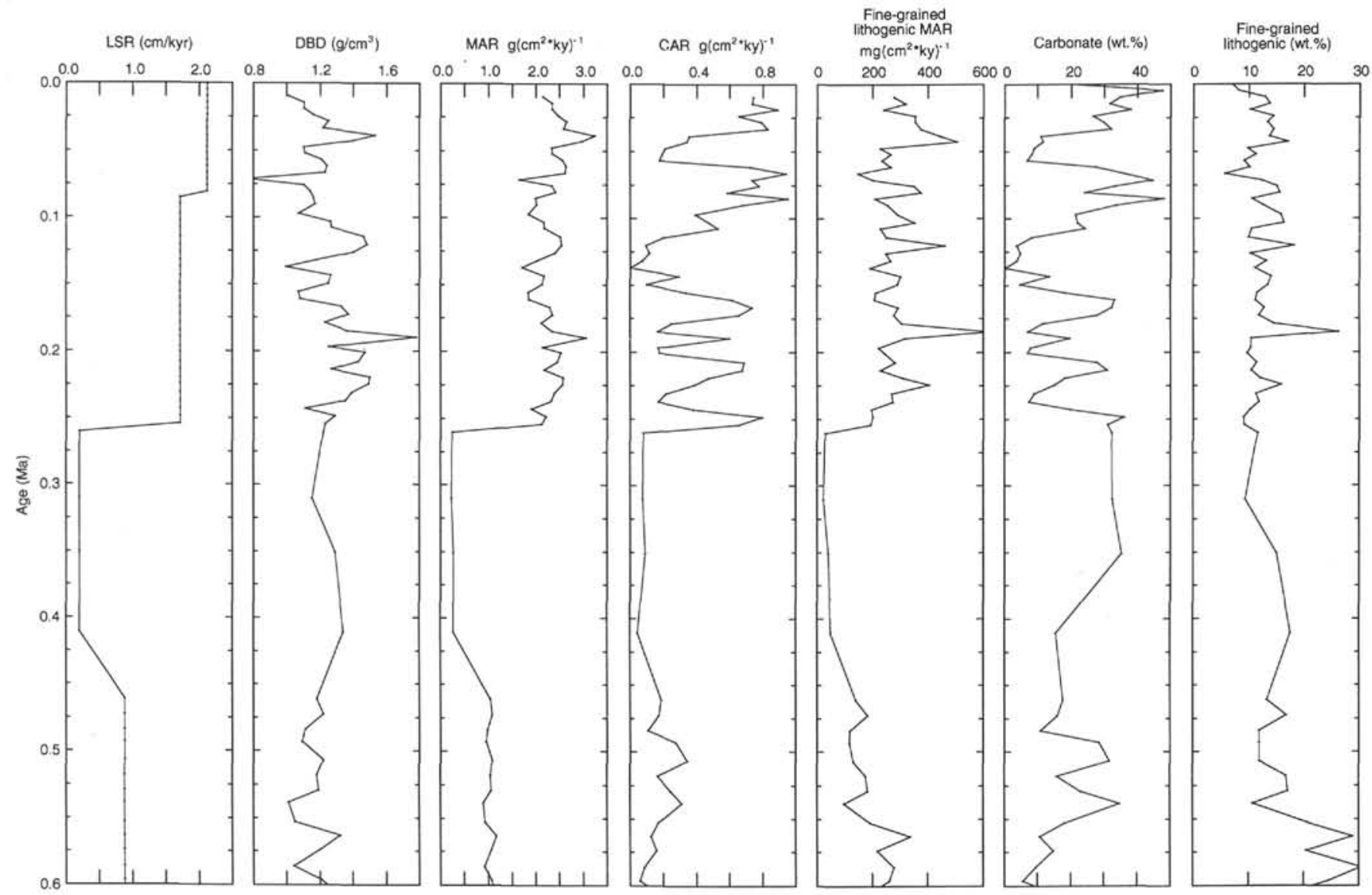

Figure 13. Summary plots of sedimentologic data and mass accumulation rates vs. age (0-0.6 Ma) in Hole 880A. Data are from Rack, Lawyer, and Gee (this volume). 


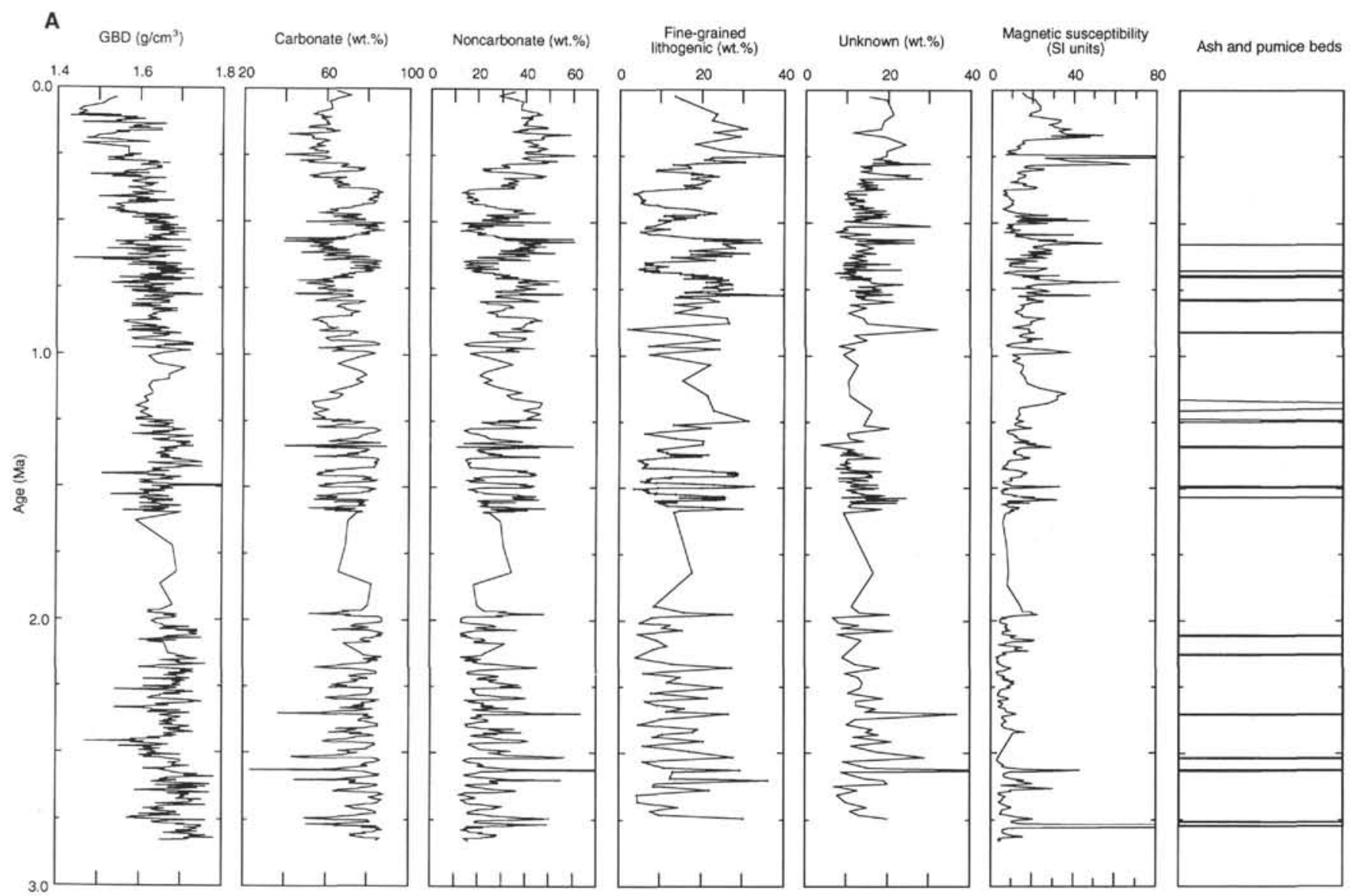

Figure 14. A. Summary plots of GRAPE bulk density (GBD), sedimentologic data, the positions of ash and pumice layers (Natland, 1993), and low-field magnetic susceptibility at Hole $810 \mathrm{C}$ on Shatsky Rise. The "unknown" sediment component is suspected to be largely composed of biogenic opal, coarse-grained lithogenic grains, oxides and hydroxides, and organic carbon. B. Summary plots of linear sedimentation rates, dry bulk density, and mass accumulation rates vs. age ( $0-3$ $\mathrm{Ma}$ ) in Hole 810C. 


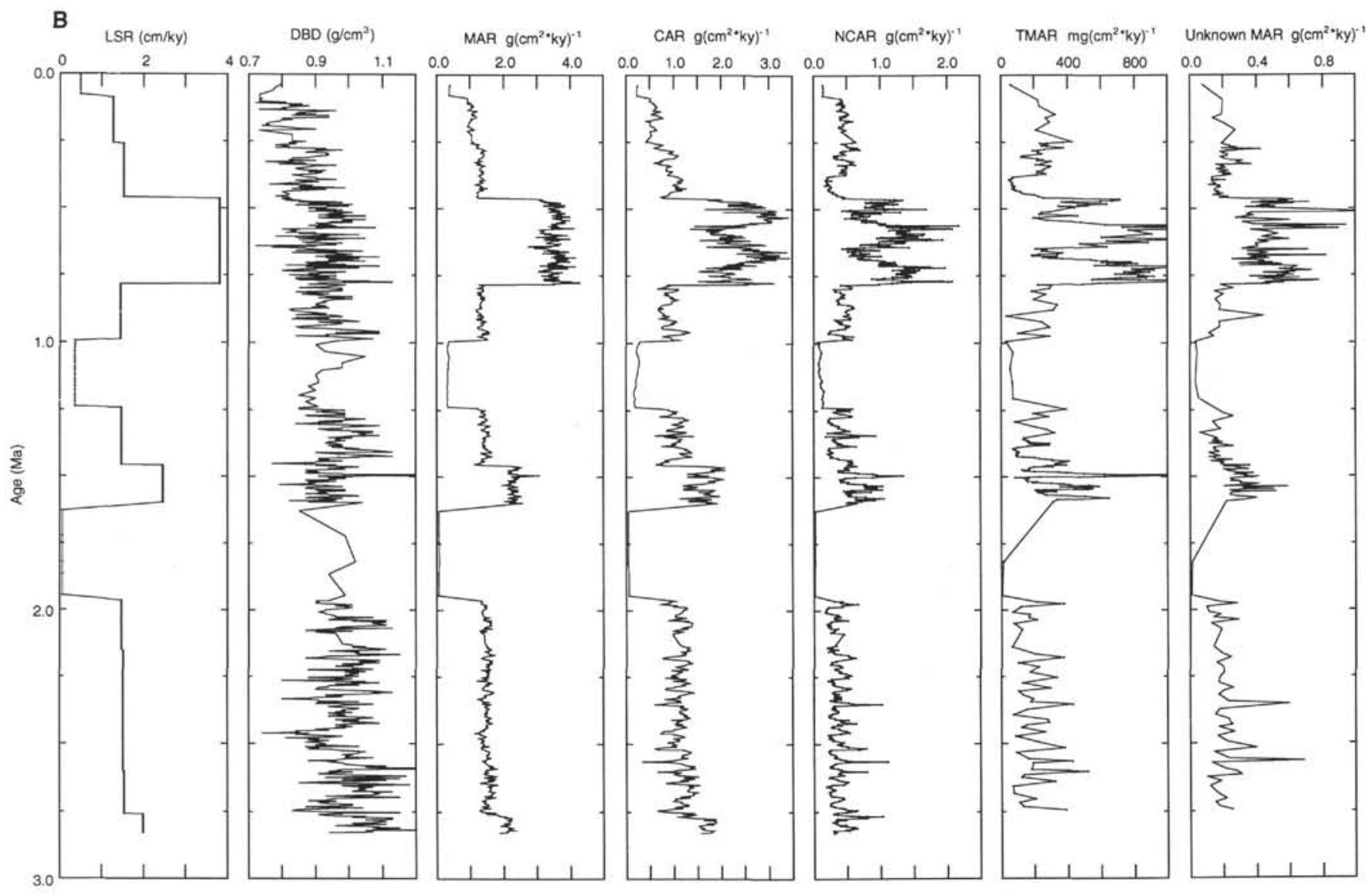

Figure 14 (continued). 
F.R. RACK ET AL.

\section{A}
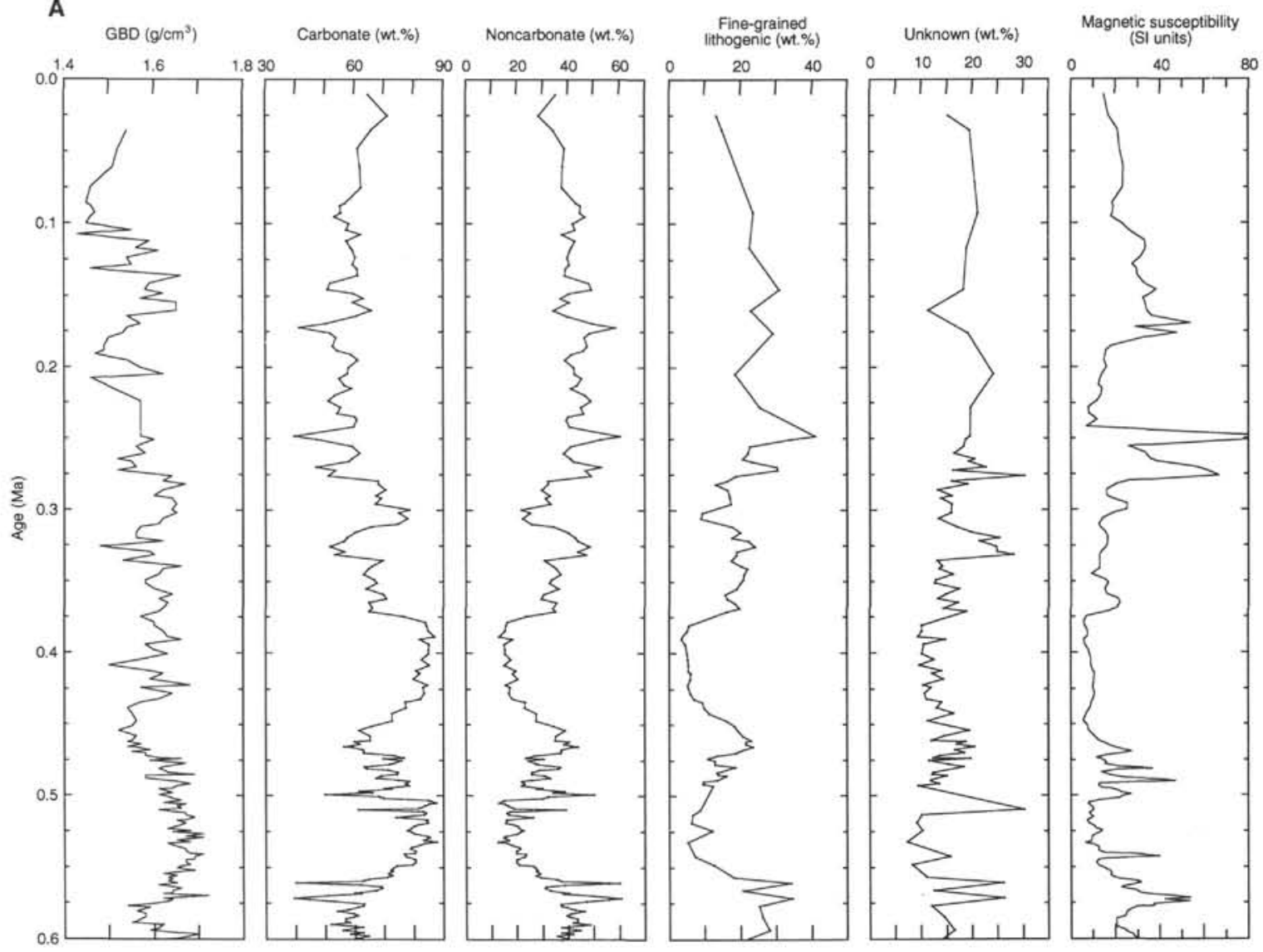

Magnetic susceptibility

100

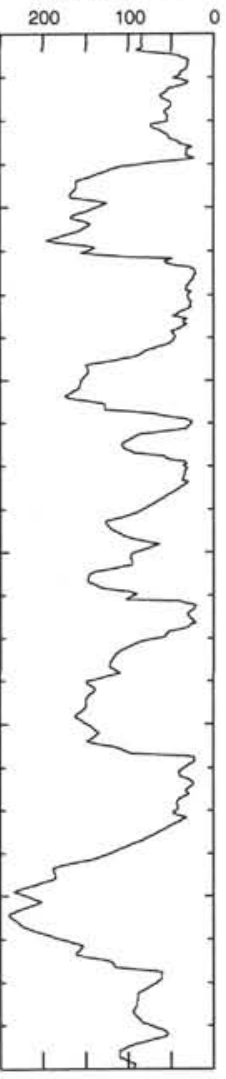

Figure 15. A. Summary plots of GRAPE bulk density (GBD), sedimentologic data, and low-field magnetic susceptibility vs. age ( $0-0.6 \mathrm{Ma})$ in Hole $810 \mathrm{C}$. Data are from Rack et al. (1993) and Rack, Lawyer, and Gee (this volume). The magnetic susceptibility record from the Xifeng I site in Central China for the same time interval is also shown; susceptibility data are from Kukla et al. (1990). B. Summary plots of mass accumulation rates vs. age (0-0.6 Ma) in Hole 810C. 
SYNTHESIS OF TERRIGENOUS ACCUMULATION RATES

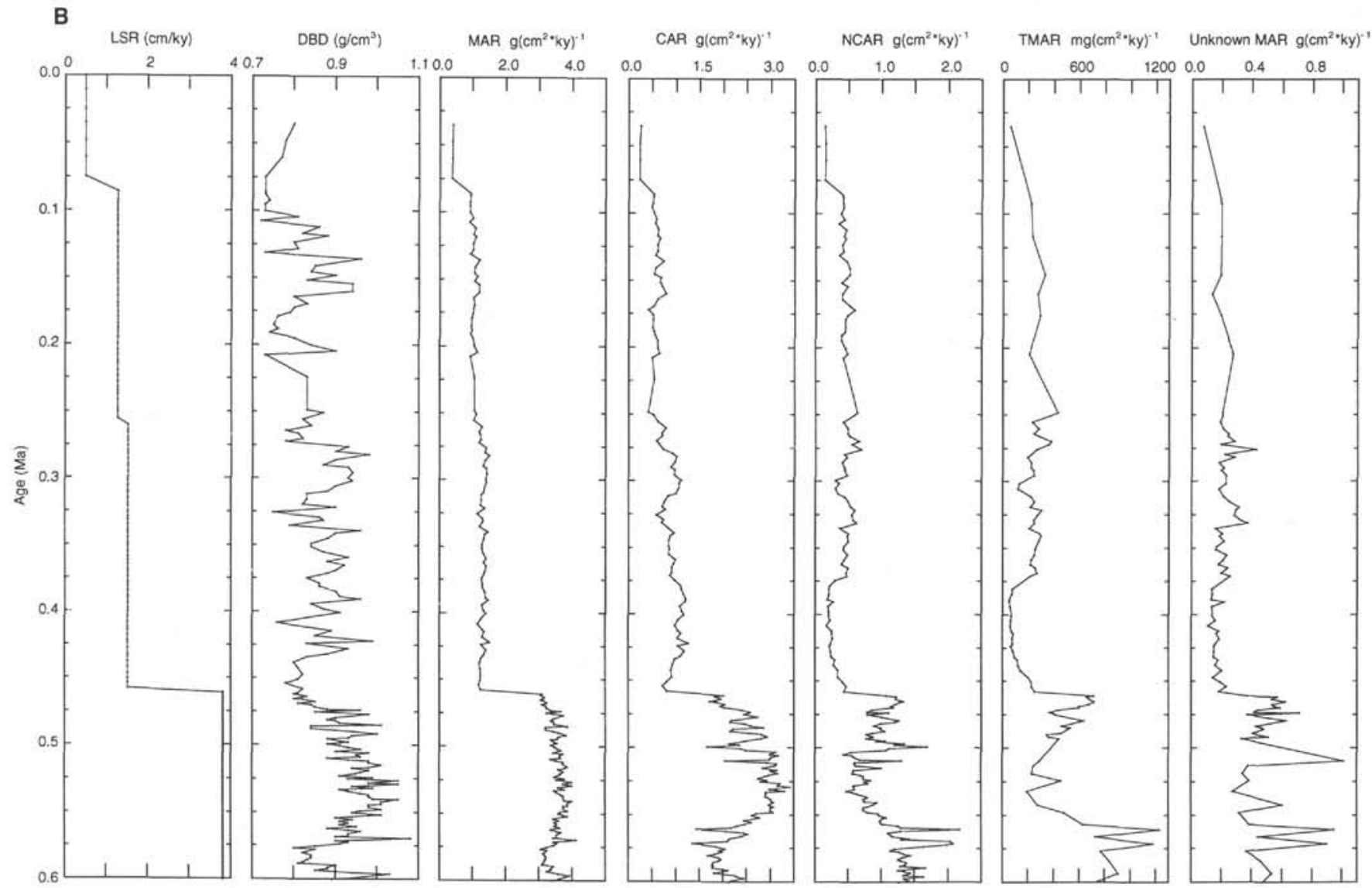

Figure 15 (continued). 


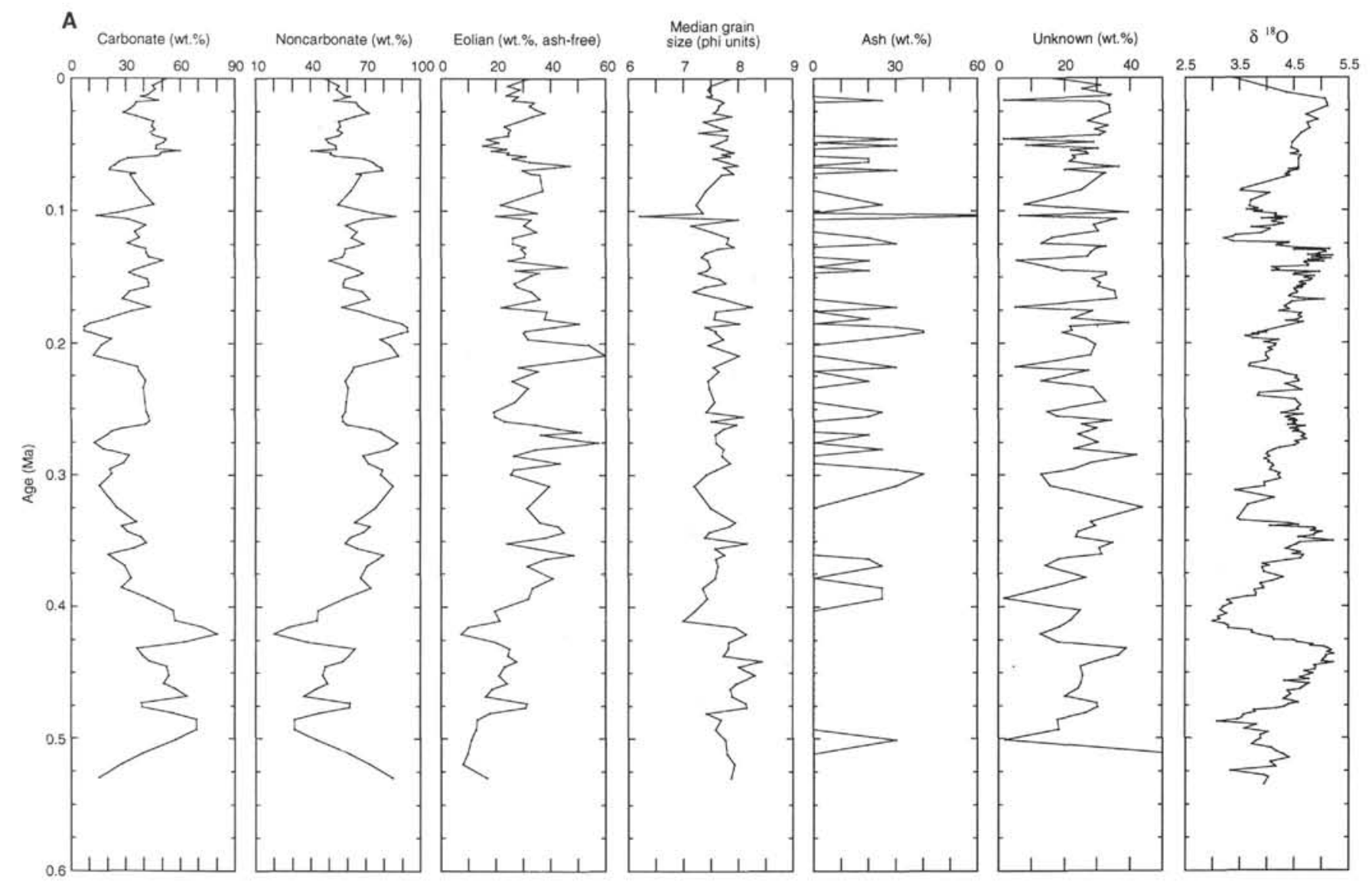

Figure 16. A. Summary plots of sedimentologic data, median eolian grain size (in phi units), and oxygen isotope stratigraphy vs. age ( $0-0.6 \mathrm{Ma}$ ) for piston Core V21-146 (northwest Pacific). Data are from Hovan et al. (1991). The percentage of "unknown" material is suspected to be largely composed of biogenic opal, coarse-grained lithogenic grains, oxides, hydroxides, zeolites, and organic carbon. B. Summary plots of mass accumulation rates vs. age (0-0.6 Ma) for piston Core V21-146. 
SYNTHESIS OF TERRIGENOUS ACCUMULATION RATES

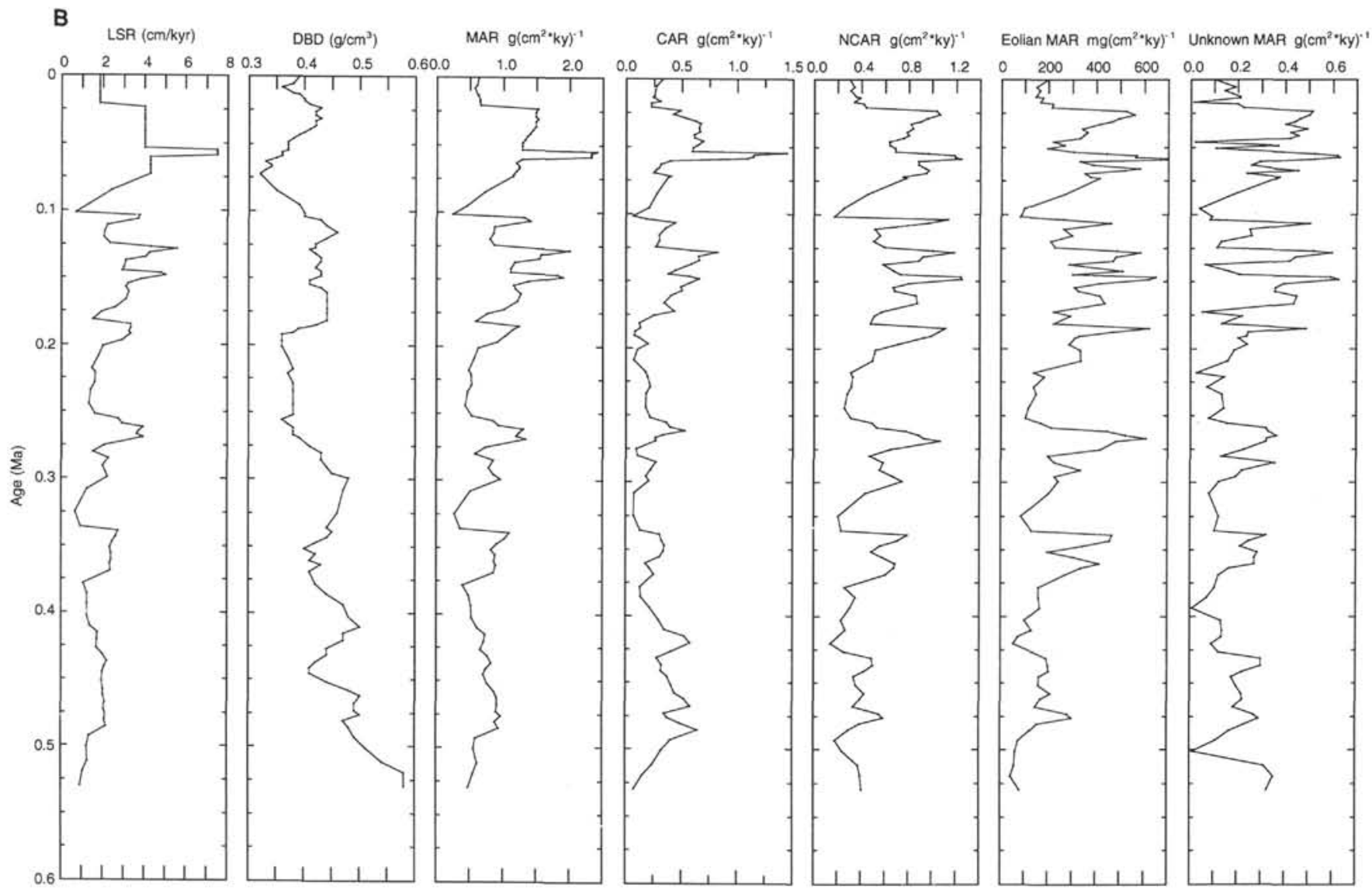

Figure 16 (continued). 


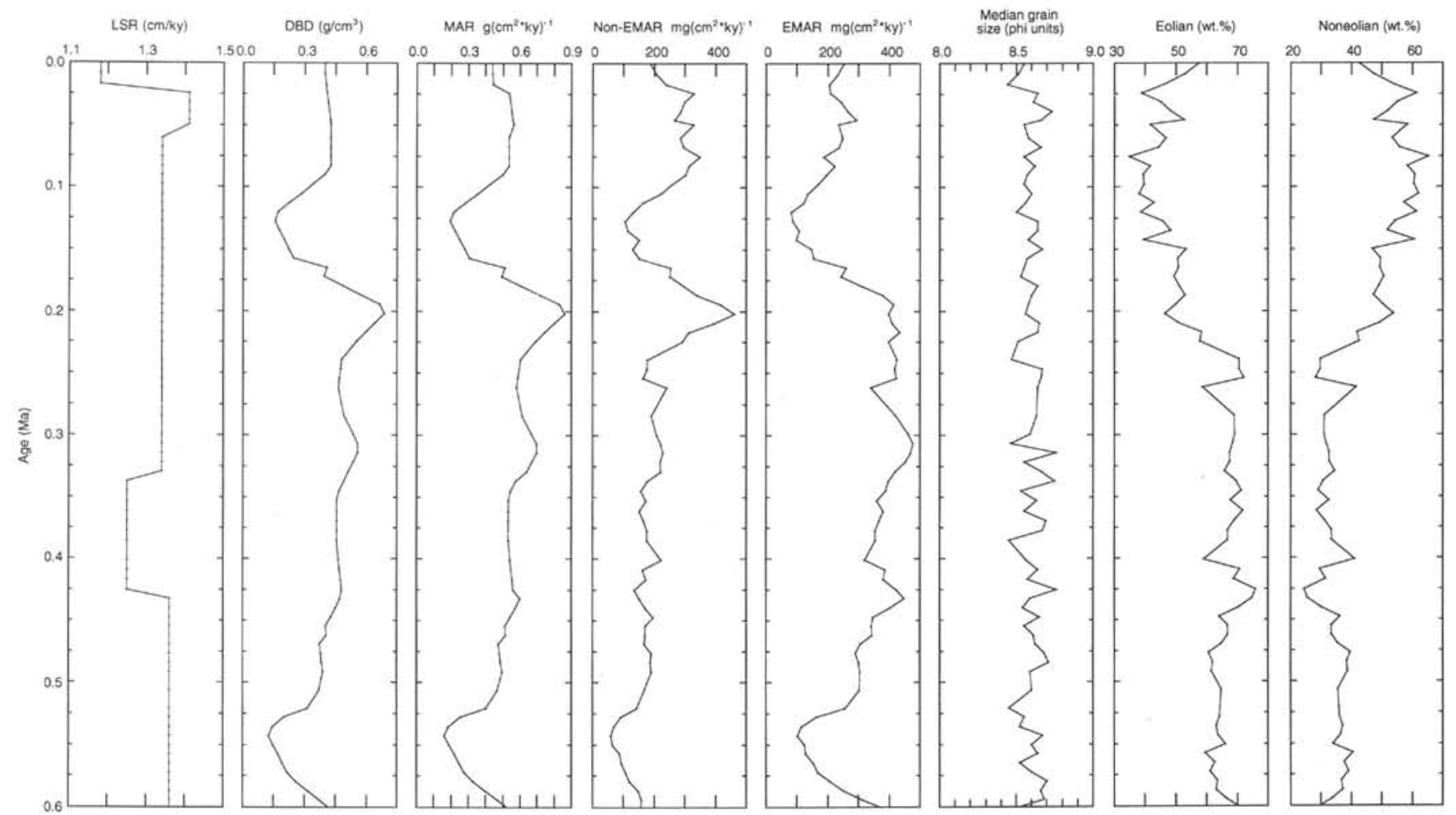

Figure 17. Summary plots of sedimentologic data and mass accumulation rates vs. age ( $0-0.6 \mathrm{Ma}$ ) for piston Core KK75-02. Data are from Janecek (1983). The weight percentage of noneolian material equals the difference of $100 \%$ - wt $\%$ eolian material.
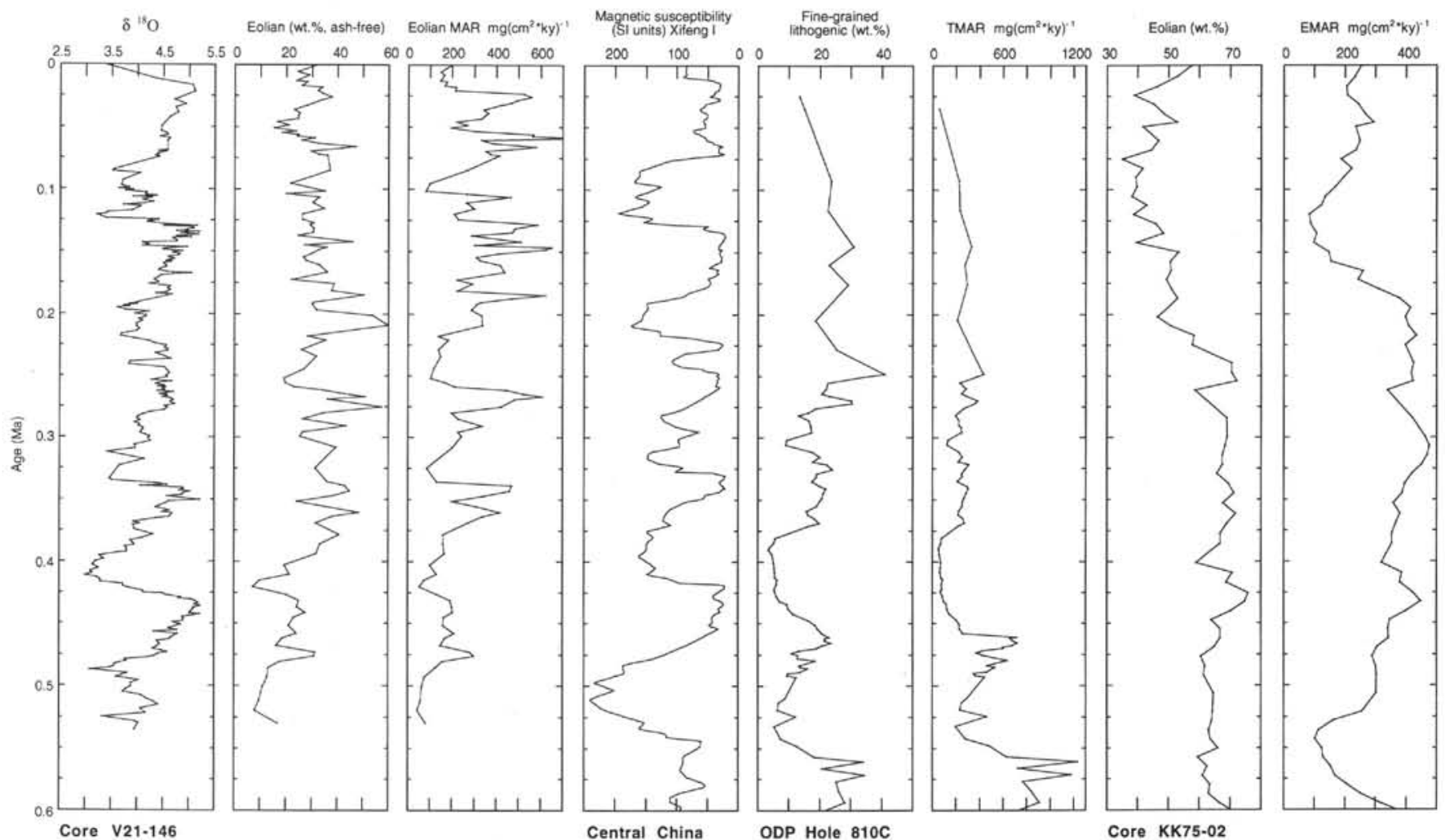

Figure 18. Comparisons between selected Pacific "eolian" records and the magnetic susceptibility record from Xifeng I, in Central China. Magnetic susceptibility data from the loess record at Xifeng I are from Kukla et al. (1990). The marine data from piston Core V21-146 represent the only record that has been correlated to the continental record (Hovan et al., 1989, 1991). The record from Hole $810 \mathrm{C}$ is poorly resolved over the upper $0.2 \mathrm{~m} . \mathrm{y}$. , but it provides the opportunity to correlate older intervals ( $>0.5 \mathrm{Ma}$; see Fig. 14) with the continental loess records from Central China (Rack and Janecek, unpubl. data). 
APPENDIX A

Linear Sedimentation and Mass Accumulation Rates for Samples from Hole 880A (Takuyo-Daisan Guyot)

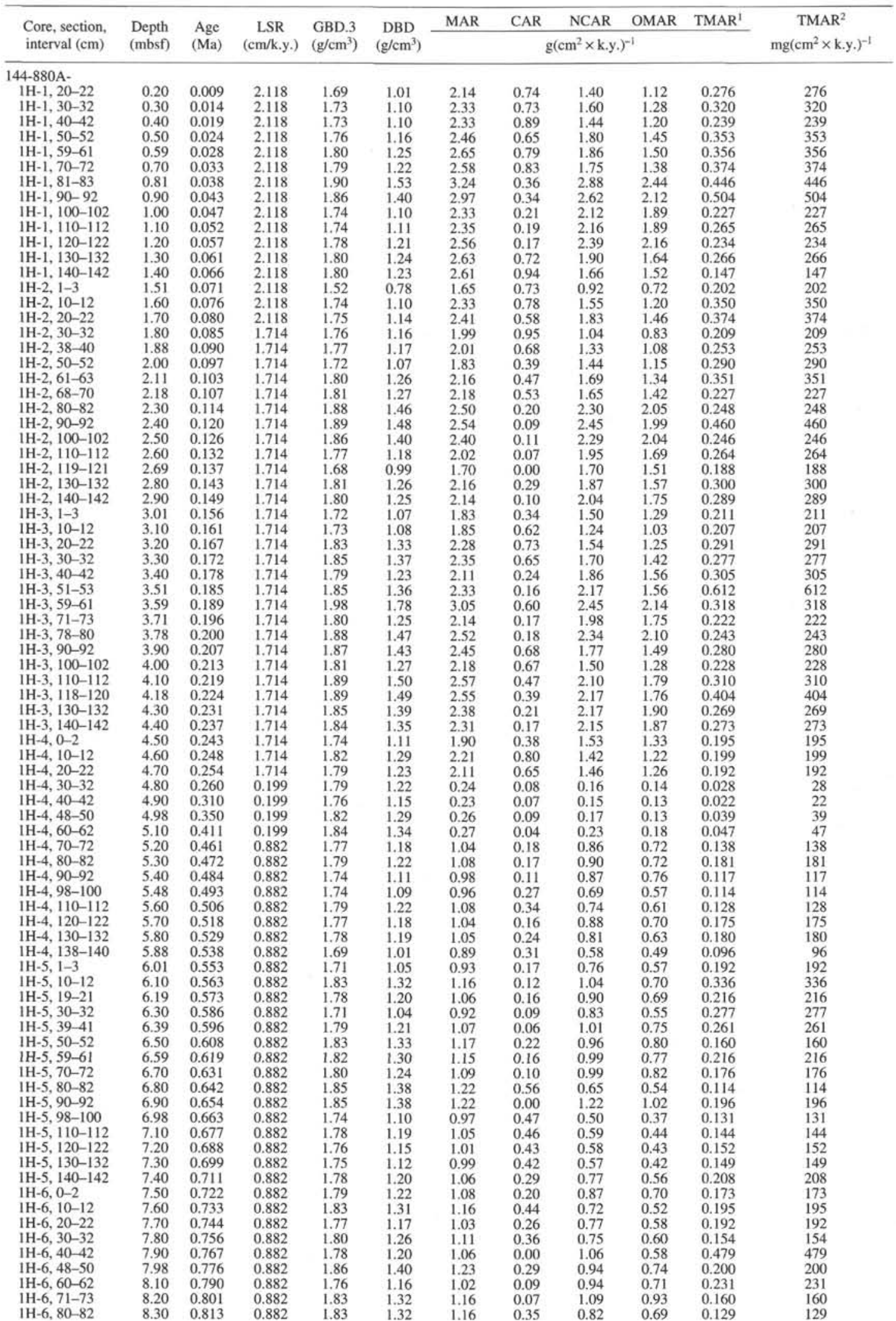


APPENDIX A (continued).

\begin{tabular}{|c|c|c|c|c|c|c|c|}
\hline ction, & Depth & Age & SR & GBD.3 & DBD & MAR & CAR \\
\hline interval $(\mathrm{cm})$ & (mbsf) & (Ma) & $(\mathrm{cm} / \mathrm{k} . \mathrm{y})$. & $\left(\mathrm{g} / \mathrm{cm}^{3}\right)$ & $\left(\mathrm{g} / \mathrm{cm}^{3}\right)$ & & \\
\hline $1 \mathrm{H}-6,90-92$ & 8.40 & 0.824 & 0.882 & 1.83 & 1.33 & 1.17 & 0.33 \\
\hline $1 \mathrm{H}-6,100-102$ & 8.50 & 0.835 & 0.882 & 1.77 & 1.18 & 1.04 & 0.24 \\
\hline $1 \mathrm{H}-6,110-112$ & 8.60 & 0.847 & 0.882 & 1.61 & 0.89 & 0.78 & 0.20 \\
\hline $2 \mathrm{H}-1,5-7$ & 8.95 & 0.886 & 0.882 & 1.54 & 0.80 & 0.71 & 0.10 \\
\hline $2 \mathrm{H}-1,11-13$ & 9.01 & 0.893 & 0.882 & 1.70 & 1.03 & 0.91 & 0.13 \\
\hline $2 \mathrm{H}-1,20-22$ & 9.10 & 0.903 & 0.882 & 1.68 & 0.99 & 0.87 & 0.34 \\
\hline $2 \mathrm{H}-1,29-31$ & 9.19 & 0.914 & 0.882 & 1.62 & 0.89 & 0.78 & 0.36 \\
\hline $2 \mathrm{H}-1,40-42$ & 9.30 & 0.926 & 0.882 & 1.69 & 1.00 & 0.88 & 0.28 \\
\hline $2 \mathrm{H}-1,50-52$ & 9.40 & 0.937 & 0.882 & 1.72 & 1.07 & 0.94 & 0.33 \\
\hline $2 \mathrm{H}-1,59-61$ & 9.49 & 0.947 & 0.882 & 1.71 & 1.06 & 0.93 & 0.25 \\
\hline $2 \mathrm{H}-1,71-73$ & 9.61 & 0.961 & 0.882 & 1.61 & 0.88 & 0.78 & 0.25 \\
\hline $2 \mathrm{H}-1,80-82$. & 9.70 & 0.971 & 0.882 & 1.77 & $\begin{array}{l}1.180 \\
1.18\end{array}$ & 1.04 & 0.17 \\
\hline $2 \mathrm{H}-1,90-92$ & 9.80 & 0.983 & 0.882 & 1.63 & 0.91 & 0.80 & 0.12 \\
\hline $2 \mathrm{H}-1,100-102$ & 9.90 & 0.994 & 0.882 & 1.72 & 1.07 & 0.94 & 0.27 \\
\hline $2 \mathrm{H}-1,110-112$ & 10.00 & 1.005 & 0.882 & 1.69 & 1.02 & 0.90 & 0.32 \\
\hline $2 \mathrm{H}-1,120-122$ & 10.10 & 1.017 & 0.882 & 1.78 & 1.21 & 1.07 & 0.15 \\
\hline $2 \mathrm{H}-1,130-132$ & 10.20 & 1.028 & 0.656 & 1.73 & 1.08 & 0.71 & 0.09 \\
\hline $2 \mathrm{H}-2,0-2$ & 10.27 & 1.039 & 0.656 & 1.74 & 1.11 & 0.73 & 0.10 \\
\hline $2 \mathrm{H}-2,10-12$ & 10.37 & 1.054 & 0.656 & 1.81 & 1.27 & 0.83 & 0.13 \\
\hline $2 \mathrm{H}-2,20-22$ & 10.47 & 1.069 & 0.656 & 1.80 & 1.26 & 0.83 & 0.31 \\
\hline $2 \mathrm{H}-2,27-29$ & 10.54 & 1.080 & 0.656 & 1.83 & 1.31 & 0.86 & 0.27 \\
\hline $2 \mathrm{H}-2,40-42$ & 10.67 & 1.100 & 0.656 & 1.81 & 1.28 & 0.84 & 0.19 \\
\hline $2 \mathrm{H}-2,50-52$ & 10.77 & 1.115 & 0.656 & $\begin{array}{l}1.01 \\
1.76\end{array}$ & 1.15 & 0.75 & 0.29 \\
\hline $2 \mathrm{H}-2,57-59$ & 10.84 & 1.126 & 0.656 & 1.75 & 1.13 & 0.74 & 0.19 \\
\hline $2 \mathrm{H}-2,70-72$ & 10.97 & 1.145 & 0.656 & 1.79 & 1.23 & 0.81 & 0.10 \\
\hline $2 \mathrm{H}-2,77-79$ & 11.04 & 1.156 & 0.656 & 1.77 & 1.17 & 0.77 & 0.14 \\
\hline $2 \mathrm{H}-2,90-92$ & 11.17 & 1.176 & 0.656 & 1.85 & 1.38 & 0.91 & 0.24 \\
\hline $2 \mathrm{H}-2,100-102$ & 11.27 & 1.191 & 0.656 & 1.86 & $\begin{array}{l}1.40 \\
\end{array}$ & 0.92 & 0.17 \\
\hline $2 \mathrm{H}-2,110-112$ & 11.37 & 1.206 & 0.656 & 1.81 & 1.27 & 0.83 & 0.08 \\
\hline $2 \mathrm{H}-2,120-122$ & 11.47 & 1.222 & 0.656 & 1.72 & 1.08 & 0.71 & 0.11 \\
\hline $2 \mathrm{H}-2,132-134$ & 11.59 & 1.240 & 0.515 & 1.73 & 1.08 & 0.56 & 0.15 \\
\hline $2 \mathrm{H}-2,140-142$ & 11.67 & 1.255 & 0.515 & 1.73 & 1.10 & 0.57 & 0.14 \\
\hline $2 \mathrm{H}-3,1-3$ & 11.78 & 1.277 & 0.515 & 1.56 & 0.83 & 0.43 & 0.08 \\
\hline $2 \mathrm{H}-3,10-12$ & 11.87 & 1.294 & 0.515 & $\begin{array}{l}1.80 \\
1.81\end{array}$ & $\begin{array}{l}.63 \\
1.27\end{array}$ & 0.65 & 0.09 \\
\hline $2 \mathrm{H}-3,20-22$ & 11.97 & 1.314 & 0.515 & $\begin{array}{l}1.01 \\
1.76\end{array}$ & 1.15 & 0.59 & 0.10 \\
\hline $2 \mathrm{H}-3,27-29$ & 12.04 & 1.327 & 0.515 & 1.76 & 1.15 & 0.59 & 0.07 \\
\hline $2 \mathrm{H}-3,40-42$ & 12.17 & 1.353 & 0.515 & 1.80 & 1.24 & 0.64 & 0.08 \\
\hline $2 \mathrm{H}-3,50-52$ & 12.27 & 1.372 & 0.515 & 1.75 & 1.12 & 0.58 & 0.09 \\
\hline $2 \mathrm{H}-3,58-60$ & 12.35 & 1.388 & 0.515 & 1.73 & $\begin{array}{l}1.09 \\
\end{array}$ & 0.56 & 0.09 \\
\hline $2 \mathrm{H}-3,70-72$ & 12.47 & 1.411 & 0.515 & 1.80 & 1.24 & 0.64 & 0.08 \\
\hline $2 \mathrm{H}-3,80-82$ & 12.57 & 1.430 & 0.515 & 1.77 & 1.17 & 0.60 & 0.17 \\
\hline $2 \mathrm{H}-3,90-92$ & 12.67 & 1.450 & 0.515 & 1.82 & 1.29 & 0.66 & 0.16 \\
\hline $2 \mathrm{H}-3,97-99$ & 12.74 & 1.463 & 0.515 & 1.79 & 1.23 & 0.63 & 0.08 \\
\hline $2 \mathrm{H}-3,110-112$ & 12.87 & $\begin{array}{l}1.489 \\
\text {. }\end{array}$ & 0.515 & 1.82 & 1.29 & 0.66 & 0.06 \\
\hline $2 \mathrm{H}-3,120-122$ & 12.97 & $\begin{array}{l}1.508 \\
1.508\end{array}$ & 0.515 & 1.77 & 1.17 & 0.60 & 0.19 \\
\hline $2 \mathrm{H}-3,130-132$ & 13.07 & 1.528 & 0.515 & 1.88 & 1.47 & 0.76 & 0.13 \\
\hline $2 \mathrm{H}-3,140-142$ & 13.17 & 1.547 & 2.800 & 1.77 & 1.19 & 3.33 & 0.38 \\
\hline $2 \mathrm{H}-4,0-2$ & 13.27 & 1.551 & 2.800 & 1.79 & 1.22 & 3.42 & 0.50 \\
\hline $2 \mathrm{H}-4,10-12$ & 13.37 & 1.554 & 2.800 & 1.84 & 1.34 & 3.75 & 0.92 \\
\hline $2 \mathrm{H}-4,20-22$ & 13.47 & 1.558 & 2.800 & $\begin{array}{l}1.04 \\
1.81\end{array}$ & $\begin{array}{l}1.27 \\
1.27\end{array}$ & 3.56 & 0.88 \\
\hline $2 \mathrm{H}-4,30-32$ & $\begin{array}{l}13.57 \\
13.57\end{array}$ & 1.561 & 2.800 & 1.83 & 1.33 & 3.72 & 0.79 \\
\hline $2 \mathrm{H}-4,40-42$ & 13.67 & 1.565 & 2.800 & $\begin{array}{l}1.80 \\
1.82\end{array}$ & 1.31 & 3.67 & 1.42 \\
\hline $2 \mathrm{H}-4,50-52$ & 13.77 & 1.568 & 2.800 & 1.80 & 1.24 & 3.47 & 0.62 \\
\hline $2 \mathrm{H}-4,57-59$ & 13.84 & 1.571 & 2.800 & 1.78 & 1.19 & 3.33 & 0.33 \\
\hline $2 \mathrm{H}-4,72-74$ & 13.99 & 1.576 & 2.800 & $\begin{array}{l}1.80 \\
1.80\end{array}$ & 1.25 & 3.50 & 0.74 \\
\hline $2 \mathrm{H}-4,80-82$ & 14.07 & 1.579 & 2.800 & 1.74 & 1.12 & 3.14 & 0.55 \\
\hline $2 \mathrm{H}-4,90-92$ & 14.17 & 1.583 & 2.800 & 1.73 & 1.10 & 3.08 & 0.33 \\
\hline $2 \mathrm{H}-4,100-102$ & 14.27 & 1.586 & 2.800 & 1.73 & 1.08 & 3.02 & 0.15 \\
\hline $2 \mathrm{H}-4,110-112$ & 14.37 & 1.590 & 2.800 & 1.80 & 1.25 & 3.50 & 1.14 \\
\hline $2 \mathrm{H}-4,120-122$ & 14.47 & 1.593 & 2.800 & 1.75 & 1.13 & 3.16 & 0.74 \\
\hline $2 \mathrm{H}-4,130-132$ & 14.57 & 1.597 & 2.222 & 1.77 & 1.17 & 2.60 & 0.80 \\
\hline $2 \mathrm{H}-4,140-142$ & 14.67 & 1.602 & 2.222 & 1.81 & 1.26 & 2.80 & 0.76 \\
\hline $2 \mathrm{H}-5,0-2$ & 14.77 & 1.606 & 2.222 & 1.74 & 1.11 & 2.47 & 0.30 \\
\hline $2 \mathrm{H}-5,10-12$ & 14.87 & 1.610 & 2.222 & 1.85 & 1.39 & 3.09 & 0.29 \\
\hline $2 \mathrm{H}-5,20-22$ & 14.97 & 1.615 & 2.222 & 1.80 & 1.25 & 2.78 & 0.77 \\
\hline $2 \mathrm{H}-5,30-32$ & 15.07 & 1.620 & 2.222 & 1.86 & 1.41 & 3.13 & 0.58 \\
\hline $2 \mathrm{H}-5,40-42$ & 15.17 & 1.624 & 2.222 & 1.89 & 1.48 & 3.29 & 0.55 \\
\hline $2 \mathrm{H}-5,50-52$ & 15.27 & 1.628 & 2.222 & 1.83 & 1.34 & 2.98 & 0.38 \\
\hline $2 \mathrm{H}-5,62-64$ & 15.39 & 1.634 & 2.222 & 1.86 & 1.42 & 3.16 & 0.39 \\
\hline $2 \mathrm{H}-5,72-74$ & 15.49 & 1.638 & 2.222 & 1.87 & 1.44 & 3.20 & 0.72 \\
\hline $2 \mathrm{H}-5,80-82$ & 15.57 & 1.642 & 2.222 & 1.84 & 1.36 & 3.02 & 0.36 \\
\hline $2 \mathrm{H}-5,88-90$ & 15.65 & $\begin{array}{l}1.042 \\
1.646\end{array}$ & 2.222 & $\begin{array}{l}1.84 \\
1.79\end{array}$ & 1.23 & 2.73 & $\begin{array}{l}0.00 \\
0.04\end{array}$ \\
\hline $2 \mathrm{H}-5,100-102$ & 15.77 & 1.651 & 2.222 & 1.87 & 1.43 & 3.18 & 0.71 \\
\hline $2 \mathrm{H}-5,109-111$ & 15.86 & 1.655 & 2.222 & 1.79 & 1.23 & 2.73 & 0.36 \\
\hline $2 \mathrm{H}-5,120-122$ & 15.97 & 1.660 & 0.133 & 1.84 & 1.35 & 0.18 & 0.05 \\
\hline $2 \mathrm{H}-5,129-131$ & 16.06 & 1.727 & 0.133 & 1.85 & 1.39 & 0.18 & 0.05 \\
\hline $2 \mathrm{H}-5,136-138$ & 16.13 & 1.780 & 0.133 & 1.72 & 1.07 & 0.14 & 0.04 \\
\hline $2 \mathrm{H}-6,0-2$ & 16.27 & 1.885 & 0.133 & 1.74 & 1.10 & 0.15 & 0.03 \\
\hline $2 \mathrm{H}-6,10-12$ & 16.37 & 1.960 & 0.133 & 1.83 & 1.31 & 0.17 & 0.05 \\
\hline $2 \mathrm{H}-6,20-22$ & 16.47 & 2.035 & 0.133 & $\begin{array}{l}1.03 \\
1.70\end{array}$ & 1.03 & 0.14 & 0.03 \\
\hline $2 \mathrm{H}-6,30-32$ & 16.57 & 2.110 & 0.133 & 1.74 & 1.11 & 0.15 & 0.03 \\
\hline $2 \mathrm{H}-6,40-42$ & 16.67 & 2.185 & 0.133 & 1.73 & 1.08 & 0.14 & 0.05 \\
\hline $2 \mathrm{H}-6,50-52$ & $\begin{array}{l}16.01 \\
16.77\end{array}$ & 2.260 & 0.133 & 1.80 & 1.25 & 0.17 & 0.05 \\
\hline $2 \mathrm{H}-6,60-62$ & 16.87 & 2.335 & 0.133 & $\begin{array}{l}1.80 \\
1.81\end{array}$ & 1.26 & 0.17 & 0.04 \\
\hline & 16.96 & 2.402 & 0.133 & $\begin{array}{l}1.71 \\
1.73\end{array}$ & 1.10 & 0.15 & 0.02 \\
\hline $2 \mathrm{H}-6,81-83$ & $\begin{array}{l}17.90 \\
17.08\end{array}$ & 2.402 & 0.133 & 1.77 & 1.16 & 0.15 & $\begin{array}{l}0.02 \\
0.02\end{array}$ \\
\hline $2 \mathrm{H}-6,90-92$ & 17.17 & 2.560 & 0.133 & 1.77 & 1.16 & 0.15 & 0.03 \\
\hline $2 \mathrm{H}-6,97-99$ & 17.24 & 2.612 & 0.133 & 1.80 & 1.25 & 0.17 & 0.03 \\
\hline $2 \mathrm{H}-6,110-112$ & 17.37 & 2.710 & 0.133 & 1.74 & 1.10 & 0.15 & 0.02 \\
\hline
\end{tabular}


APPENDIX A (continued).

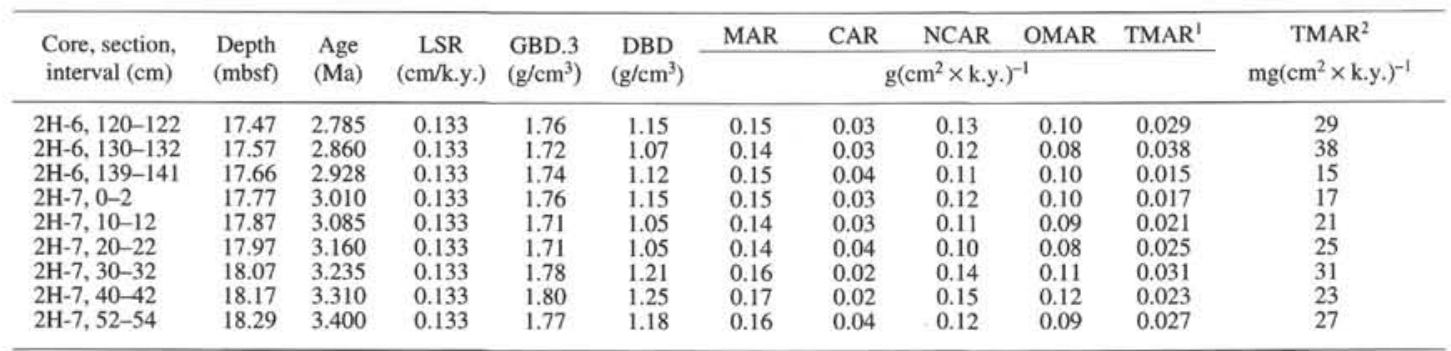

Notes: Depth $(\mathrm{mbsf})=$ sub-bottom depth in meters below seafloor; age $(\mathrm{Ma})=$ millions of years ago; LSR = linear sedimentation rate $(\mathrm{cm}$ per thousand years); GBD.3 = GRAPE bulk density ( 3 point smoothed, $\left.\mathrm{g} / \mathrm{cm}^{3}\right) ; \mathrm{DBD}=$ dry bulk density $\left(\mathrm{g} / \mathrm{cm}^{3}\right) ;$ MAR = mass (bulk) accumulation rate (grams of sediment per square $\mathrm{cm}$ per thousand years; same units for other rates); $\mathrm{CAR}=$ carbonate accumulation rate; $\mathrm{NCAR}=$ noncarbonate accumulation rate; $\mathrm{OMAR}=$ noncarbonate minus eolian accumulation rate; $\mathrm{TMAR}=\mathrm{terrigenous}$ accumulation rate (lithogenic material $<63 \mu \mathrm{m})$ in units of $\mathrm{g}\left(\mathrm{cm}^{2} \times \mathrm{k} . \mathrm{y} .\right)^{-1} ; \mathrm{TMAR}^{2}=$ terrigenous accumulation rate in units of mg $\left(\mathrm{cm}^{2} \times \mathrm{k} . \mathrm{y} \text {. }\right)^{-1}$. The carbonate and noncarbonate weight percentage data used to calculate these accumulation rates are contained in Rack et al. (Data Report, this volume). 
APPENDIX B

Results of Chemical Extractions of Lithogenic Material in Samples from Hole 810C (Shatsky Rise)

\begin{tabular}{|c|c|c|c|c|}
\hline $\begin{array}{l}\text { Core, section, } \\
\text { interval }(\mathrm{cm})\end{array}$ & $\begin{array}{l}\text { Depth } \\
\text { (mbsf) }\end{array}$ & $\begin{array}{l}\text { Age } \\
(\mathrm{Ma})\end{array}$ & $\begin{array}{c}\text { Fine-grained } \\
\text { lithogenic } \\
\text { (wt \%) }\end{array}$ & $\begin{array}{c}\text { Noncarb. - } \\
\text { fine-grained } \\
\text { lithogenic } \\
\text { (wt\%) }\end{array}$ \\
\hline \multicolumn{5}{|l|}{$132-810 \mathrm{C}-$} \\
\hline $1 \mathrm{H}-1,11.5$ & 0.12 & 0.025 & 13.40 & 15.26 \\
\hline $1 \mathrm{H}-1,17.5$ & 0.17 & 0.035 & 14.83 & 19.49 \\
\hline $1 \mathrm{H}-1,50.5$ & 0.50 & 0.092 & 23.58 & 21.09 \\
\hline $1 \mathrm{H}-1,80.5$ & 0.81 & 0.117 & 22.46 & 18.82 \\
\hline $1 \mathrm{H}-1,116.6$ & 1.17 & 0.146 & 30.85 & 18.23 \\
\hline $1 \mathrm{H}-1,134.5$ & 1.35 & 0.160 & 22.85 & 11.31 \\
\hline IH-2.5.5 & 1.55 & 0.176 & 29.16 & 19.18 \\
\hline 1H-2, 41.5 & 1.91 & 0.204 & 18.37 & 24.07 \\
\hline $1 \mathrm{H}-2,71.5$ & 2.21 & 0.228 & 25.34 & 19.60 \\
\hline $2 \mathrm{H}-1,5.5$ & 2.46 & 0.248 & 40.97 & 19.45 \\
\hline $2 \mathrm{H}-1,8.5$ & 2.49 & 0.250 & 33.94 & 18.58 \\
\hline $2 \mathrm{H}-1,14.5$ & 2.55 & 0.255 & 22.59 & 18.28 \\
\hline $2 \mathrm{H}-1,20.5$ & 2.61 & 0.260 & 21.95 & 16.40 \\
\hline $2 \mathrm{H}-1,26.5$ & 2.67 & 0.264 & 20.62 & 20.42 \\
\hline $2 \mathrm{H}-1,29.6$ & 2.70 & 0.266 & 22.82 & 19.24 \\
\hline $2 \mathrm{H}-1,35.5$ & 2.76 & 0.270 & 30.24 & 22.63 \\
\hline $2 \mathrm{H}-1,38.5$ & 2.79 & 0.272 & 30.41 & 16.17 \\
\hline $2 \mathrm{H}-1,44.5$ & 2.85 & 0.276 & 18.69 & 30.17 \\
\hline $2 \mathrm{H}-1,50.6$ & 2.91 & 0.280 & 16.22 & 15.92 \\
\hline $2 \mathrm{H}-1,53.5$ & 2.94 & 0.282 & 12.94 & 19.00 \\
\hline $2 \mathrm{H}-1,59.6$ & 3.00 & 0.286 & 16.28 & 13.21 \\
\hline $2 \mathrm{H}-1,65.5$ & 3.06 & 0.290 & 16.88 & 15.88 \\
\hline $2 \mathrm{H}-1,68.5$ & 3.09 & 0.292 & 17.10 & 13.84 \\
\hline $2 \mathrm{H}-1,74.5$ & 3.15 & 0.296 & 17.13 & 15.92 \\
\hline $2 \mathrm{H}-1.83 .5$ & 3.24 & 0.301 & 9.25 & 15.79 \\
\hline $2 \mathrm{H}-1,89.5$ & 3.30 & 0.306 & 8.95 & 13.25 \\
\hline $2 \mathrm{H}-1,98.5$ & 3.39 & 0.311 & 17.59 & 16.74 \\
\hline $2 \mathrm{H}-1,104.5$ & 3.45 & 0.315 & 19.96 & 19.71 \\
\hline $2 \mathrm{H}-1,110.7$ & 3.51 & 0.319 & 17.49 & 25.24 \\
\hline $2 \mathrm{H}-1,113.7$ & 3.54 & 0.321 & 22.18 & 21.42 \\
\hline $2 \mathrm{H}-1,119.5$ & 3.60 & 0.325 & 23.94 & 24.56 \\
\hline $2 \mathrm{H}-\mathrm{I}, 125.5$ & 3.66 & 0.329 & 18.87 & 24.81 \\
\hline $2 \mathrm{H}-1,128.5$ & 3.69 & 0.331 & 18.75 & 28.07 \\
\hline $2 \mathrm{H}-1,134.5$ & 3.75 & 0.335 & 17.40 & 13.09 \\
\hline $2 \mathrm{H}-1,140.6$ & 3.81 & 0.339 & 20.05 & 13.98 \\
\hline $2 \mathrm{H}-1,143.5$ & 3.84 & 0.341 & 21.87 & 13.46 \\
\hline $2 \mathrm{H}-1,149.5$ & 3.90 & 0.345 & 20.98 & 16.12 \\
\hline $2 \mathrm{H}-2,5.5$ & 3.96 & 0.349 & 20.51 & 12.83 \\
\hline $2 \mathrm{H}-2,8.5$ & 3.99 & 0.351 & 19.95 & 12.55 \\
\hline $2 \mathrm{H}-2,14.5$ & 4.05 & 0.355 & 18.85 & 17.37 \\
\hline $2 \mathrm{H}-2,20.5$ & 4.11 & 0.359 & 15.66 & 14.67 \\
\hline $2 \mathrm{H}-2,26.5$ & 4.16 & 0.362 & 16.16 & 13.14 \\
\hline $2 \mathrm{H}-2,29.5$ & 4.20 & 0.365 & 18.04 & 17.18 \\
\hline $2 \mathrm{H}-2,35.5$ & 4.26 & 0.369 & 19.67 & 14.29 \\
\hline $2 \mathrm{H}-2,38.5$ & 4.29 & 0.371 & 16.11 & 18.92 \\
\hline $2 \mathrm{H}-2,53.6$ & 4.44 & 0.381 & 5.53 & 10.11 \\
\hline $2 \mathrm{H}-2,59.5$ & 4.50 & 0.385 & 5.03 & 10.01 \\
\hline $2 \mathrm{H}-2,65.5$ & 4.56 & 0.389 & 3.63 & 9.33 \\
\hline $2 \mathrm{H}-2,68.6$ & 4.59 & 0.391 & 3.39 & 14.66 \\
\hline $2 \mathrm{H}-2,74.5$ & 4.64 & 0.394 & 4.40 & 10.42 \\
\hline $2 \mathrm{H}-2,83.5$ & 4.74 & 0.400 & 5.00 & 10.06 \\
\hline $2 \mathrm{H}-2,89.5$ & 4.80 & 0.404 & 5.11 & 12.40 \\
\hline $2 \mathrm{H}-2,95.5$ & 4.86 & 0.408 & 5.41 & 9.57 \\
\hline $2 \mathrm{H}-2,101.6$ & 4.92 & 0.412 & 5.36 & 13.91 \\
\hline $2 \mathrm{H}-2,104.5$ & 4.95 & 0.414 & 6.05 & 12.04 \\
\hline $2 \mathrm{H}-2,110.5$ & 5.01 & 0.418 & 5.86 & 14.35 \\
\hline $2 \mathrm{H}-2,116.6$ & 5.07 & 0.422 & 5.22 & 10.32 \\
\hline $2 \mathrm{H}-2,119.7$ & 5.10 & 0.424 & 5.31 & 11.76 \\
\hline $2 \mathrm{H}-2,125.5$ & 5.16 & 0.428 & 5.95 & 10.62 \\
\hline $2 \mathrm{H}-2,131.5$ & 5.22 & 0.432 & 7.00 & 10.92 \\
\hline $2 \mathrm{H}-2,134.5$ & 5.25 & 0.434 & 9.14 & 13.86 \\
\hline $2 \mathrm{H}-2,140.7$ & 5.31 & 0.438 & 9.84 & 12.91 \\
\hline $2 \mathrm{H}-2,146.6$ & 5.37 & 0.442 & 11.12 & 16.28 \\
\hline $2 \mathrm{H}-3,5.5$ & 5.45 & 0.447 & 16.20 & II $.2 \mathrm{I}$ \\
\hline $2 \mathrm{H}-3,11.5$ & 5.51 & 0.451 & 18.34 & 15.58 \\
\hline $2 \mathrm{H}-3,14.5$ & 5.55 & 0.454 & 19.24 & 19.40 \\
\hline $2 \mathrm{H}-3,20.5$ & 5.61 & 0.458 & 20.57 & 14.36 \\
\hline $2 \mathrm{H}-3,26.5$ & 5.66 & 0.461 & 22.97 & 11.91 \\
\hline $2 \mathrm{H}-3,29.5$ & 5.70 & 0.462 & 21.53 & 18.59 \\
\hline $2 \mathrm{H}-3,35.5$ & 5.76 & 0.464 & 21.51 & 16.84 \\
\hline $2 \mathrm{H}-3,41.5$ & 5.82 & 0.465 & 23.47 & 20.35 \\
\hline $2 \mathrm{H}-3,50.5$ & 5.91 & 0.468 & 20.66 & 16.57 \\
\hline $2 \mathrm{H}-3,56.5$ & 5.97 & 0.469 & 19.31 & 17.76 \\
\hline $2 \mathrm{H}-3,59.5$ & 6.00 & 0.470 & 18.63 & 18.33 \\
\hline $2 \mathrm{H}-3,65.5$ & 6.06 & 0.472 & 13.25 & 13.48 \\
\hline $2 \mathrm{H}-3,71.5$ & 6.12 & 0.473 & 10.96 & 12.36 \\
\hline $2 \mathrm{H}-3,74.6$ & 6.15 & 0.474 & 10.77 & 19.60 \\
\hline $2 \mathrm{H}-3,80.5$ & 6.20 & 0.475 & 12.82 & 11.44 \\
\hline $2 \mathrm{H}-3,89.6$ & 6.30 & 0.478 & 12.75 & 15.43 \\
\hline $2 \mathrm{H}-3,95.5$ & 6.36 & 0.479 & 18.50 & 18.20 \\
\hline $2 \mathrm{H}-3,110.6$ & 6.51 & 0.483 & 13.30 & 12.29 \\
\hline $2 \mathrm{H}-3,116.5$ & 6.57 & 0.485 & 13.64 & 12.04 \\
\hline $2 \mathrm{H}-3,119.5$ & 6.60 & 0.486 & 15.89 & 14.92 \\
\hline $2 \mathrm{H}-3,131.6$ & 6.72 & 0.489 & 13.40 & 11.85 \\
\hline
\end{tabular}

\begin{tabular}{|c|c|c|c|c|}
\hline $\begin{array}{l}\text { Core, section, } \\
\text { interval }(\mathrm{cm})\end{array}$ & $\begin{array}{l}\text { Depth } \\
\text { (mbsf) }\end{array}$ & $\begin{array}{l}\text { Age } \\
\text { (Ma) }\end{array}$ & $\begin{array}{l}\text { Fine-grained } \\
\text { lithogenic } \\
(w t \%)\end{array}$ & $\begin{array}{c}\text { Noncarb. - } \\
\text { fine-grained } \\
\text { lithogenic } \\
(w t \%)\end{array}$ \\
\hline $2 \mathrm{H}-3,134.6$ & 6.75 & 0.490 & 9.66 & 11.97 \\
\hline $2 \mathrm{H}-3,140.7$ & 6.81 & 0.491 & 9.48 & 13.38 \\
\hline $2 \mathrm{H}-3,146.5$ & 6.87 & 0.493 & 12.30 & 9.32 \\
\hline $2 \mathrm{H}-4,59.5$ & 7.50 & 0.509 & 8.71 & 30.19 \\
\hline $2 \mathrm{H}-4,74.5$ & 7.64 & 0.513 & 6.61 & 10.02 \\
\hline $2 \mathrm{H}-4,95.6$ & 7.86 & 0.519 & 6.22 & 9.11 \\
\hline $2 \mathrm{H}-4,116.5$ & 8.07 & 0.524 & 12.14 & 10.18 \\
\hline $2 \mathrm{H}-4,146.5$ & 8.36 & 0.532 & 5.15 & 7.26 \\
\hline $2 \mathrm{H}-5,35.5$ & 8.75 & 0.542 & 7.20 & 15.60 \\
\hline $2 \mathrm{H}-5,56.6$ & 8.97 & 0.548 & 12.43 & 8.20 \\
\hline $2 \mathrm{H}-5,89.5$ & 9.30 & 0.557 & 18.10 & 11.08 \\
\hline $2 \mathrm{H}-5,104.6$ & 9.45 & 0.561 & 33.97 & 26.09 \\
\hline $2 \mathrm{H}-5,125.6$ & 9.66 & 0.566 & 20.52 & 12.42 \\
\hline $2 \mathrm{H}-5,146.5$ & 9.86 & 0.571 & 34.38 & 26.24 \\
\hline $2 \mathrm{H}-6,14.5$ & 10.05 & 0.576 & 25.17 & 11.98 \\
\hline $2 \mathrm{H}-6,44.5$ & 10.34 & 0.584 & 26.05 & 14.40 \\
\hline $2 \mathrm{H}-6,80.5$ & 10.70 & 0.593 & 27.94 & 16.40 \\
\hline $2 \mathrm{H}-6,119.7$ & 11.10 & 0.604 & 17.04 & 12.26 \\
\hline $2 \mathrm{H}-6,146.6$ & 11.37 & 0.611 & 31.39 & 16.83 \\
\hline $2 \mathrm{H}-7,14.5$ & 11.55 & 0.616 & 17.33 & 11.18 \\
\hline $2 \mathrm{H}-7,44.5$ & 11.84 & 0.623 & 27.04 & 14.47 \\
\hline $3 \mathrm{H}-1,14.5$ & 12.05 & 0.629 & 12.68 & 10.57 \\
\hline $3 \mathrm{H}-1,50.6$ & 12.41 & 0.638 & 23.14 & 14.96 \\
\hline $3 \mathrm{H}-1,86.5$ & 12.76 & 0.648 & 6.21 & 9.40 \\
\hline $3 \mathrm{H}-1,101.6$ & 12.92 & 0.652 & 7.93 & 20.50 \\
\hline $3 \mathrm{H}-1,119.5$ & 13.09 & 0.656 & 6.47 & 9.14 \\
\hline $3 \mathrm{H}-1,146.6$ & 13.37 & 0.664 & 11.63 & 14.68 \\
\hline $3 \mathrm{H}-2,5.7$ & 13.46 & 0.666 & 9.13 & 11.10 \\
\hline $3 \mathrm{H}-2,11.7$ & 13.52 & 0.668 & 6.17 & 9.20 \\
\hline $3 \mathrm{H}-2,14.5$ & 13.55 & 0.668 & 6.06 & 9.81 \\
\hline $3 \mathrm{H}-2,20.5$ & 13.60 & 0.670 & 5.91 & 10.05 \\
\hline $3 \mathrm{H}-2,26.5$ & 13.66 & 0.671 & 4.92 & 9.30 \\
\hline $3 \mathrm{H}-2,29.7$ & 13.70 & 0.672 & 4.86 & 9.75 \\
\hline $3 \mathrm{H}-2,35.5$ & 13.75 & 0.674 & 5.44 & 23.16 \\
\hline $3 \mathrm{H}-2,41.5$ & 13.81 & 0.675 & 8.60 & 10.01 \\
\hline $3 \mathrm{H}-2,44.5$ & 13.84 & 0.676 & 9.07 & 10.01 \\
\hline $3 \mathrm{H}-2,50.5$ & 13.90 & 0.678 & 9.54 & 11.69 \\
\hline $3 \mathrm{H}-2,56.5$ & 13.96 & 0.679 & 8.84 & 10.44 \\
\hline $3 \mathrm{H}-2,59.5$ & 13.99 & 0.680 & 6.07 & 11.11 \\
\hline $3 \mathrm{H}-2,65.5$ & 14.05 & 0.682 & 7.66 & 9.37 \\
\hline $3 \mathrm{H}-2,71.6$ & 14.12 & 0.683 & 7.99 & 12.06 \\
\hline $3 \mathrm{H}-2,74.7$ & 14.15 & 0.684 & 9.33 & 12.17 \\
\hline $3 \mathrm{H}-2,80.5$ & 14.20 & 0.685 & 9.70 & 8.53 \\
\hline $3 \mathrm{H}-2,89.6$ & 14.30 & 0.688 & 14.96 & 7.05 \\
\hline $3 \mathrm{H}-2,101.6$ & 14.42 & 0.691 & 14.73 & 11.52 \\
\hline $3 \mathrm{H}-2,104.6$ & 14.45 & 0.692 & 17.79 & 11.73 \\
\hline $3 \mathrm{H}-2,110.7$ & 14.51 & 0.693 & 15.86 & 10.65 \\
\hline $3 \mathrm{H}-2,119.5$ & 14.59 & 0.696 & 21.35 & 11.85 \\
\hline $3 \mathrm{H}-2,125.5$ & 14.65 & 0.697 & 17.57 & 13.26 \\
\hline $3 \mathrm{H}-2,131.5$ & 14.72 & 0.699 & 18.48 & 13.61 \\
\hline $3 \mathrm{H}-2,134.5$ & 14.74 & 0.700 & 17.90 & 12.95 \\
\hline $3 \mathrm{H}-2,140.5$ & 14.80 & 0.701 & 19.27 & 10.49 \\
\hline $3 \mathrm{H}-2,146.5$ & 14.86 & 0.703 & 22.83 & 8.27 \\
\hline $3 \mathrm{H}-3,5.7$ & 14.96 & 0.705 & 20.89 & 15.89 \\
\hline $3 \mathrm{H}-3,11.5$ & 15.01 & 0.707 & 19.28 & 15.40 \\
\hline $3 \mathrm{H}-3,20.5$ & 15.10 & 0.709 & 15.80 & 11.84 \\
\hline $3 \mathrm{H}-3,26.5$ & 15.16 & 0.711 & 24.04 & 9.76 \\
\hline $3 \mathrm{H}-3,29.5$ & 15.19 & 0.711 & 24.39 & 13.76 \\
\hline $3 \mathrm{H}-3,35.5$ & 15.25 & 0.713 & 26.35 & 15.61 \\
\hline $3 \mathrm{H}-3,71.5$ & 15.61 & 0.723 & 20.96 & 15.73 \\
\hline $3 \mathrm{H}-3,74.6$ & 15.65 & 0.724 & 22.48 & 16.93 \\
\hline $3 \mathrm{H}-3,80.6$ & 15.71 & 0.725 & 24.69 & 16.19 \\
\hline $3 \mathrm{H}-3,89.5$ & 15.80 & 0.727 & 26.88 & 19.32 \\
\hline $3 \mathrm{H}-3,95.5$ & 15.85 & 0.729 & 25.83 & 23.43 \\
\hline $3 \mathrm{H}-3,101.5$ & 15.91 & 0.730 & 27.31 & 22.28 \\
\hline $3 \mathrm{H}-3,104.6$ & 15.95 & 0.731 & 27.33 & 20.94 \\
\hline $3 \mathrm{H}-3,110.5$ & 16.00 & 0.733 & 24.21 & 18.92 \\
\hline $3 \mathrm{H}-3,116.6$ & 16.07 & 0.734 & 24.99 & 18.01 \\
\hline $3 \mathrm{H}-3,119.5$ & 16.09 & 0.735 & 23.60 & 16.73 \\
\hline $3 \mathrm{H}-3,131.6$ & 16.22 & 0.738 & 23.27 & 12.78 \\
\hline $3 \mathrm{H}-3,134.5$ & 16.24 & 0.739 & 22.24 & 14.10 \\
\hline $3 \mathrm{H}-3,140.5$ & 16.31 & 0.741 & 21.07 & 16.21 \\
\hline $3 \mathrm{H}-3,146.5$ & 16.36 & 0.742 & 20.45 & 16.73 \\
\hline $3 \mathrm{H}-4,5.5$ & 16.45 & 0.744 & 23.83 & 16.37 \\
\hline $3 \mathrm{H}-4,11.5$ & 16.51 & 0.746 & 24.00 & 18.24 \\
\hline $3 \mathrm{H}-4,14.5$ & 16.55 & 0.747 & 27.44 & 16.73 \\
\hline $3 \mathrm{H}-4,20.6$ & 16.61 & 0.749 & 26.24 & 17.82 \\
\hline $3 \mathrm{H}-4,26.5$ & 16.66 & 0.750 & 25.13 & 14.89 \\
\hline $3 \mathrm{H}-4,29.5$ & 16.69 & 0.751 & 24.56 & 10.75 \\
\hline $3 \mathrm{H}-4,41.5$ & 16.82 & 0.754 & 24.34 & 15.11 \\
\hline $3 \mathrm{H}-4,44.6$ & 16.85 & 0.755 & 19.98 & 18.43 \\
\hline $3 \mathrm{H}-4,65.5$ & 17.06 & 0.761 & 15.88 & 12.24 \\
\hline $3 \mathrm{H}-4,71.7$ & 17.12 & 0.762 & 16.34 & 12.28 \\
\hline $3 \mathrm{H}-4,74.6$ & 17.15 & 0.763 & 21.58 & 15.47 \\
\hline $3 \mathrm{H}-4,80.5$ & 17.20 & 0.764 & 23.41 & 14.27 \\
\hline
\end{tabular}


APPENDIX B (continued).

\begin{tabular}{|c|c|c|c|c|}
\hline $\begin{array}{l}\text { Core, section, } \\
\text { interval }(\mathrm{cm})\end{array}$ & $\begin{array}{l}\text { Depth } \\
\text { (mbsf) }\end{array}$ & $\begin{array}{l}\text { Age } \\
(\mathrm{Ma})\end{array}$ & $\begin{array}{l}\text { Fine-grained } \\
\text { lithogenic } \\
(w t \%)\end{array}$ & $\begin{array}{l}\text { Noncarb. - } \\
\text { fine-grained } \\
\text { lithogenic } \\
\text { (wt\%) }\end{array}$ \\
\hline $3 \mathrm{H}-4,89.5$ & 17.30 & 0.767 & 31.33 & 21.04 \\
\hline $3 \mathrm{H}-4,95.5$ & 17.35 & 0.768 & 35.60 & 19.98 \\
\hline $3 \mathrm{H}-4,101.6$ & 17.42 & 0.770 & 33.16 & 18.19 \\
\hline $3 \mathrm{H}-4,104.7$ & 17.45 & 0.771 & 39.61 & 14.67 \\
\hline $3 \mathrm{H}-4,110.5$ & 17.50 & 0.772 & 26.50 & 12.01 \\
\hline $3 \mathrm{H}-4,119.5$ & 17.59 & 0.775 & 14.69 & 12.81 \\
\hline $3 \mathrm{H}-4,125.5$ & 17.65 & 0.776 & 15.13 & 14.41 \\
\hline $3 \mathrm{H}-4,131.5$ & 17.72 & 0.778 & 15.79 & 12.52 \\
\hline $3 \mathrm{H}-4,134.6$ & 17.75 & 0.779 & 13.79 & 13.55 \\
\hline $3 \mathrm{H}-4,140.5$ & 17.81 & 0.781 & 17.48 & 14.39 \\
\hline $3 \mathrm{H}-4,146.5$ & 17.86 & 0.784 & 21.41 & 13.49 \\
\hline $3 \mathrm{H}-5,11.5$ & 18.01 & 0.795 & 24.10 & 21.29 \\
\hline $3 \mathrm{H}-5,26.5$ & 18.16 & 0.805 & 13.35 & 10.78 \\
\hline $3 \mathrm{H}-5,41.5$ & 18.32 & 0.816 & 19.93 & 14.78 \\
\hline $3 \mathrm{H}-5,71.5$ & 18.61 & 0.837 & 13.49 & 10.38 \\
\hline $3 \mathrm{H}-5,101.5$ & 18.91 & 0.858 & 26.16 & 14.13 \\
\hline $3 \mathrm{H}-5,128.6$ & 19.19 & 0.877 & 26.64 & 14.83 \\
\hline $3 \mathrm{H}-6,11.5$ & 19.51 & 0.900 & 2.15 & 32.10 \\
\hline $3 \mathrm{H}-6,41.7$ & 19.82 & 0.921 & 16.46 & 11.74 \\
\hline $3 \mathrm{H}-6,71.5$ & 20.11 & 0.942 & 24.31 & 14.88 \\
\hline $3 \mathrm{H}-6,101.5$ & 20.41 & 0.963 & 7.22 & 8.08 \\
\hline $3 \mathrm{H}-6,119.5$ & 20.59 & 0.975 & 24.23 & 11.92 \\
\hline $3 \mathrm{H}-6,140.7$ & 20.81 & 0.993 & 7.43 & 9.10 \\
\hline $3 \mathrm{H}-7,5.5$ & 20.95 & 1.033 & 21.97 & 12.62 \\
\hline $3 \mathrm{H}-7,26.5$ & 21.16 & 1.093 & 15.33 & 10.43 \\
\hline $3 \mathrm{H}-7,44.6$ & 21.35 & 1.148 & 21.30 & 10.70 \\
\hline $4 \mathrm{H}-1,14.5$ & 21.55 & 1.206 & 22.89 & 16.11 \\
\hline $4 \mathrm{H}-1,56.5$ & 21.97 & 1.260 & 13.17 & 14.04 \\
\hline $4 \mathrm{H}-1,74.6$ & 22.15 & 1.273 & 22.09 & 20.08 \\
\hline $4 \mathrm{H}-1,101.5$ & 22.41 & 1.291 & 6.23 & 10.07 \\
\hline $4 \mathrm{H}-1,131.5$ & 22.72 & 1.312 & 13.70 & 10.76 \\
\hline $4 \mathrm{H}-1,146.5$ & 22.86 & 1.321 & 20.40 & 14.03 \\
\hline $4 \mathrm{H}-2,14.5$ & 23.05 & 1.334 & 20.35 & 3.74 \\
\hline $4 \mathrm{H}-2,41.6$ & 23.32 & 1.353 & 9.79 & 11.77 \\
\hline $4 \mathrm{H}-2,44.5$ & 23.34 & 1.354 & 9.38 & 11.05 \\
\hline $4 \mathrm{H}-2,50.5$ & 23.40 & 1.358 & 9.33 & 10.05 \\
\hline $4 \mathrm{H}-2,56.6$ & 23.47 & 1.363 & 10.52 & 12.26 \\
\hline $4 \mathrm{H}-2,59.5$ & 23.49 & 1.365 & 11.62 & 9.09 \\
\hline $4 \mathrm{H}-2,65.5$ & 23.56 & 1.369 & 11.63 & 14.06 \\
\hline $4 \mathrm{H}-2,71.7$ & 23.62 & 1.373 & 21.53 & 8.47 \\
\hline $4 \mathrm{H}-2,74.7$ & 23.65 & 1.375 & 12.54 & 11.89 \\
\hline $4 \mathrm{H}-2,80.5$ & 23.70 & 1.379 & 19.84 & 14.89 \\
\hline $4 \mathrm{H}-2,89.5$ & 23.80 & 1.386 & 11.02 & 18.07 \\
\hline $4 \mathrm{H}-2,95.6$ & 23.86 & 1.390 & 6.83 & 10.08 \\
\hline $4 \mathrm{H}-2,101.5$ & 23.91 & 1.393 & 4.67 & 10.05 \\
\hline $4 \mathrm{H}-2,104.5$ & 23.94 & 1.395 & 4.93 & 9.89 \\
\hline $4 \mathrm{H}-2,110.6$ & 24.01 & 1.400 & 5.66 & 9.56 \\
\hline $4 \mathrm{H}-2,116.5$ & 24.07 & 1.404 & 5.97 & 10.84 \\
\hline $4 \mathrm{H}-2,119.5$ & 24.09 & 1.406 & 6.51 & 10.23 \\
\hline $4 \mathrm{H}-2,125.5$ & 24.15 & 1.410 & 7.03 & 8.35 \\
\hline $4 \mathrm{H}-2,131.5$ & 24.22 & 1.415 & 6.19 & 10.13 \\
\hline $4 \mathrm{H}-2,134.5$ & 24.24 & 1.416 & 6.42 & 9.86 \\
\hline $4 \mathrm{H}-2,140.5$ & 24.31 & 1.421 & 5.69 & 11.03 \\
\hline $4 \mathrm{H}-2,146.6$ & 24.37 & 1.425 & 9.00 & 7.39 \\
\hline $4 \mathrm{H}-2,149.5$ & 24.40 & 1.427 & 13.31 & 9.86 \\
\hline $4 \mathrm{H}-3,5.6$ & 24.46 & 1.431 & 17.48 & 10.61 \\
\hline $4 \mathrm{H}-3,11.5$ & 24.51 & 1.434 & 22.41 & 18.28 \\
\hline $4 \mathrm{H}-3,14.6$ & 24.55 & 1.437 & 22.97 & 15.02 \\
\hline $4 \mathrm{H}-3,20.5$ & 24.60 & 1.441 & 28.15 & 8.52 \\
\hline $4 \mathrm{H}-3,26.5$ & 24.66 & 1.445 & 28.82 & 15.11 \\
\hline $4 \mathrm{H}-3,29.5$ & 24.69 & 1.447 & 26.32 & 15.40 \\
\hline $4 \mathrm{H}-3,35.7$ & 24.76 & 1.452 & 28.71 & 16.10 \\
\hline $4 \mathrm{H}-3,41.6$ & 24.82 & 1.456 & 27.72 & 14.47 \\
\hline $4 \mathrm{H}-3,44.5$ & 24.84 & 1.457 & 12.59 & 16.18 \\
\hline $4 \mathrm{H}-3,50.5$ & 24.90 & 1.459 & 11.03 & 10.56 \\
\hline $4 \mathrm{H}-3,56.5$ & 24.97 & 1.462 & 12.42 & 7.97 \\
\hline $4 \mathrm{H}-3,59.5$ & 24.99 & 1.463 & 7.83 & 10.39 \\
\hline $4 \mathrm{H}-3,65.5$ & 25.06 & 1.466 & 6.87 & 12.11 \\
\hline $4 \mathrm{H}-3,71.5$ & 25.11 & 1.468 & 7.25 & 14.17 \\
\hline $4 \mathrm{H}-3,74.6$ & 25.15 & 1.470 & 7.31 & 15.21 \\
\hline $4 \mathrm{H}-3,80.6$ & 25.21 & 1.472 & 6.70 & 8.16 \\
\hline $4 \mathrm{H}-3,86.5$ & 25.26 & 1.474 & 5.41 & 10.72 \\
\hline $4 \mathrm{H}-3,89.6$ & 25.30 & 1.476 & 6.78 & 10.06 \\
\hline $4 \mathrm{H}-3,95.6$ & 25.36 & 1.478 & 6.27 & 10.08 \\
\hline $4 \mathrm{H}-3,101.5$ & 25.41 & 1.480 & 9.14 & 11.13 \\
\hline $4 \mathrm{H}-3,104.5$ & 25.44 & 1.481 & 15.41 & 12.04 \\
\hline $4 \mathrm{H}-3,110.5$ & 25.50 & 1.484 & 18.19 & 13.09 \\
\hline $4 \mathrm{H}-3,116.6$ & 25.57 & 1.487 & 22.91 & 17.51 \\
\hline $4 \mathrm{H}-3,119.5$ & 25.59 & 1.487 & 25.61 & 11.92 \\
\hline $4 \mathrm{H}-3,125.5$ & 25.65 & 1.490 & 28.14 & 10.92 \\
\hline $4 \mathrm{H}-3,134.5$ & 25.74 & 1.494 & 32.59 & 11.05 \\
\hline $4 \mathrm{H}-3,140.7$ & 25.81 & 1.497 & 27.87 & 14.42 \\
\hline $4 \mathrm{H}-3,146.5$ & 25.86 & 1.498 & 19.86 & 17.69 \\
\hline $4 \mathrm{H}-3,149.7$ & 25.90 & 1.500 & 9.33 & 15.82 \\
\hline $4 \mathrm{H}-4,5.5$ & 25.95 & 1.502 & 3.61 & 16.64 \\
\hline $4 \mathrm{H}-4,11.5$ & 26.01 & 1.505 & 6.99 & 11.43 \\
\hline $4 \mathrm{H}-4,14.5$ & 26.05 & 1.506 & 5.91 & 9.91 \\
\hline $4 \mathrm{H}-4,20.5$ & 26.10 & 1.508 & 6.36 & 10.71 \\
\hline
\end{tabular}

\begin{tabular}{|c|c|c|c|c|}
\hline $\begin{array}{l}\text { Core, section, } \\
\text { interval }(\mathrm{cm})\end{array}$ & $\begin{array}{l}\text { Depth } \\
\text { (mbsf) }\end{array}$ & $\begin{array}{l}\text { Age } \\
(\mathrm{Ma})\end{array}$ & $\begin{array}{c}\text { Fine-grained } \\
\text { lithogenic } \\
(w t \%)\end{array}$ & $\begin{array}{c}\text { Noncarb. - } \\
\text { fine-grained } \\
\text { lithogenic } \\
\text { (wt\%) }\end{array}$ \\
\hline $4 \mathrm{H}-4,29.6$ & 26.20 & 1.512 & 7.17 & 12.26 \\
\hline $4 \mathrm{H}-4,35.5$ & 26.25 & 1.514 & 6.88 & 12.69 \\
\hline $4 \mathrm{H}-4,41.5$ & 26.32 & 1.517 & 7.44 & 11.22 \\
\hline $4 \mathrm{H}-4,44.5$ & 26.34 & 1.518 & 9.05 & 12.69 \\
\hline $4 \mathrm{H}-4,50.5$ & 26.40 & 1.520 & 8.71 & 14.24 \\
\hline $4 \mathrm{H}-4,56.6$ & 26.47 & 1.523 & 13.63 & 13.43 \\
\hline $4 \mathrm{H}-4,59.6$ & 26.50 & 1.525 & 16.18 & 18.23 \\
\hline $4 \mathrm{H}-4,65.5$ & 26.56 & 1.527 & 17.03 & 19.13 \\
\hline $4 \mathrm{H}-4,71,6$ & 26.62 & 1.529 & 21.22 & 17.52 \\
\hline $4 \mathrm{H}-4,74.5$ & 26.65 & 1.531 & 25.07 & 16.38 \\
\hline $4 \mathrm{H}-4,86.5$ & 26.76 & 1.535 & 25.64 & 8.87 \\
\hline $4 \mathrm{H}-4,89.5$ & 26.80 & 1.537 & 14.81 & 24.39 \\
\hline $4 \mathrm{H}-4,95.7$ & 26.86 & 1.539 & 20.45 & 14.67 \\
\hline $4 \mathrm{H}-4,101.6$ & 26.92 & 1.542 & 25.02 & 18.48 \\
\hline $4 \mathrm{H}-4,104.5$ & 26.94 & 1.543 & 25.52 & 14.98 \\
\hline $4 \mathrm{H}-4,110.5$ & 27.00 & 1.545 & 23.38 & 22.37 \\
\hline $4 \mathrm{H}-4,116.6$ & 27.07 & 1.548 & 10.44 & 12.45 \\
\hline $4 \mathrm{H}-4,119.5$ & 27.09 & 1.549 & 8.87 & 14.36 \\
\hline $4 \mathrm{H}-4,125.7$ & 27.16 & 1.551 & 9.24 & 10.74 \\
\hline $4 \mathrm{H}-4,131.6$ & 27.22 & 1.554 & 13.28 & 11.92 \\
\hline $4 \mathrm{H}-4,134.5$ & 27.24 & 1.555 & 13.97 & 22.00 \\
\hline $4 \mathrm{H}-4,140.6$ & 27.31 & 1.558 & 9.71 & 15.28 \\
\hline $4 \mathrm{H}-4,146.5$ & 27.36 & 1.560 & 10.29 & 11.19 \\
\hline $4 \mathrm{H}-5,14.6$ & 27.55 & 1.567 & 11.66 & 10.32 \\
\hline $4 \mathrm{H}-5,29.5$ & 27.69 & 1.573 & 20.25 & 10.95 \\
\hline $4 \mathrm{H}-5,41.5$ & 27.82 & 1.578 & 29.93 & 18.52 \\
\hline $4 \mathrm{H}-5,56.6$ & 27.97 & 1.584 & 14.72 & 14.77 \\
\hline $4 \mathrm{H}-5,74.6$ & 28.15 & 1.592 & 13.31 & 9.25 \\
\hline $4 \mathrm{H}-5,101.6$ & 28.42 & 1.818 & 17.69 & 16.46 \\
\hline $4 \mathrm{H}-5,110.5$ & 28.50 & 1.944 & 8.53 & 11.18 \\
\hline $4 \mathrm{H}-5,125.5$ & 28.65 & 1.969 & 15.86 & 13.14 \\
\hline $4 \mathrm{H}-5,134.5$ & 28.74 & 1.976 & 27.50 & 20.49 \\
\hline $4 \mathrm{H}-5,149.5$ & 28.90 & 1.987 & 8.15 & 6.67 \\
\hline $4 \mathrm{H}-6,29.5$ & 29.19 & 2.006 & 5.12 & 8.26 \\
\hline $4 \mathrm{H}-6,44.5$ & 29.34 & 2.016 & 12.36 & 13.10 \\
\hline $4 \mathrm{H}-6,59.6$ & 29.50 & 2.027 & 10.46 & 8.86 \\
\hline $4 \mathrm{H}-6,71.5$ & 29.61 & 2.035 & 15.39 & 21.08 \\
\hline $4 \mathrm{H}-6,89.5$ & 29.80 & 2.048 & 4.69 & 7.88 \\
\hline $4 \mathrm{H}-6,125.5$ & 30.15 & 2.072 & 9.12 & 13.64 \\
\hline $4 \mathrm{H}-7,11.5$ & 30.51 & 2.096 & 11.62 & \\
\hline $4 \mathrm{H}-7,26.5$ & 30.66 & 2.106 & 8.38 & \\
\hline $5 \mathrm{H}-1,20.5$ & 31.10 & 2.136 & 4.11 & 8.95 \\
\hline $5 \mathrm{H}-1,59.5$ & 31.49 & 2.163 & 13.08 & 12.26 \\
\hline $5 \mathrm{H}-1,80.5$ & 31.70 & 2.177 & 27.20 & 17.84 \\
\hline $5 \mathrm{H}-1,110.5$ & 32.01 & 2.197 & 5.99 & 9.54 \\
\hline $5 \mathrm{H}-1,134.5$ & 32.24 & 2.212 & 14.72 & 12.80 \\
\hline $5 \mathrm{H}-2,14.5$ & 32.55 & 2.233 & 11.61 & 13.77 \\
\hline $5 \mathrm{H}-2,44.5$ & 32.85 & 2.253 & 25.03 & 13.39 \\
\hline $5 \mathrm{H}-2,74.5$ & 33.15 & 2.272 & 7.85 & 10.26 \\
\hline $5 \mathrm{H}-2,104.6$ & 33.45 & 2.292 & 21.43 & 18.79 \\
\hline $5 \mathrm{H}-2,119.5$ & 33.60 & 2.302 & 6.29 & 12.22 \\
\hline $5 \mathrm{H}-2,143.5$ & 33.84 & 2.318 & 9.44 & 12.23 \\
\hline $5 \mathrm{H}-3,14.5$ & 34.05 & 2.332 & 15.89 & 17.03 \\
\hline $5 \mathrm{H}-3,29.6$ & 34.20 & 2.342 & 11.52 & 14.51 \\
\hline $5 \mathrm{H}-3,44.5$ & 34.35 & 2.352 & 26.48 & 36.91 \\
\hline $5 \mathrm{H}-3,74.6$ & 34.65 & 2.372 & 10.22 & 12.07 \\
\hline $5 \mathrm{H}-3,104.5$ & 34.94 & 2.391 & 4.72 & 9.92 \\
\hline $5 \mathrm{H}-3,131.5$ & 35.22 & 2.409 & 19.01 & 16.22 \\
\hline $5 \mathrm{H}-3,146.5$ & 35.37 & 2.419 & 17.88 & 14.66 \\
\hline $5 \mathrm{H}-4,11.5$ & 35.51 & 2.429 & 10.51 & 17.75 \\
\hline $5 \mathrm{H}-4,26.5$ & 35.66 & 2.438 & 8.24 & 11.64 \\
\hline $5 \mathrm{H}-4,50.5$ & 35.90 & 2.454 & 20.50 & 20.85 \\
\hline $5 \mathrm{H}-4,74.5$ & 36.14 & 2.470 & 5.80 & 11.02 \\
\hline $5 \mathrm{H}-4,107.5$ & 36.47 & 2.492 & 17.00 & 16.95 \\
\hline $5 \mathrm{H}-4,140.5$ & 36.80 & 2.514 & 27.71 & 29.00 \\
\hline $5 \mathrm{H}-5,14.5$ & 37.05 & 2.530 & 5.76 & 9.14 \\
\hline $5 \mathrm{H}-5,50.5$ & 37.41 & 2.554 & 10.88 & 15.39 \\
\hline $5 \mathrm{H}-5,62.5$ & 37.53 & 2.562 & 29.36 & 47.21 \\
\hline $5 \mathrm{H}-5,74.5$ & 37.65 & 2.570 & 13.00 & 8.64 \\
\hline $5 \mathrm{H}-5,110.5$ & 38.01 & 2.594 & 12.32 & 14.53 \\
\hline $5 \mathrm{H}-5,119.5$ & 38.10 & 2.600 & 36.08 & 19.08 \\
\hline $5 \mathrm{H}-5,140.5$ & 38.31 & 2.614 & 8.65 & 19.94 \\
\hline $5 \mathrm{H}-6,5.5$ & 38.46 & 2.624 & 8.41 & 6.92 \\
\hline $5 \mathrm{H}-6,29.5$ & 38.69 & 2.638 & 21.86 & 12.58 \\
\hline $5 \mathrm{H}-6,56.5$ & 38.97 & 2.657 & 4.45 & 7.61 \\
\hline $5 \mathrm{H}-6,95.5$ & 39.36 & 2.682 & 4.50 & 9.84 \\
\hline $5 \mathrm{H}-6,125.5$ & 39.66 & 2.702 & 14.16 & 14.91 \\
\hline $5 \mathrm{H}-6,146.6$ & 39.87 & 2.716 & 7.64 & 10.73 \\
\hline $5 \mathrm{H}-7,20.5$ & 40.11 & 2.731 & 9.83 & 13.13 \\
\hline $5 \mathrm{H}-7,41.5$ & 40.32 & 2.745 & 30.05 & 20.00 \\
\hline
\end{tabular}

Notes: Depth $(\mathrm{mbsf})=$ sub-bottom depth in meters below seafloor; age $(\mathrm{Ma})=$ millions of years ago; fine-grained lithogenic $(w t \%)=$ weight percentage of chemically extracted lithogenic material $(<63 \mu \mathrm{m})$ relative to bulk sample weight; Noncarb. fine-grained lithogenic $(w t \%)=$ weight percentage of noncarbonate material $(100 \%$ - wt\% $\mathrm{CaCO}_{3}$; data from Rack et al., 1993) minus the weight percentage of finegrained lithogenic material $(<63 \mu \mathrm{m})$. 
APPENDIX C

Linear Sedimentation and Mass Accumulation Rates for Samples from Hole 810C (Shatsky Rise)

\begin{tabular}{|c|c|c|c|c|c|c|c|c|}
\hline & Depth & Age & & & MAR & CAR & NCAR & OMAR \\
\hline interval $(\mathrm{cm})$ & (mbsf) & (Ma) & $(\mathrm{cm} / \mathrm{k} . \mathrm{y})$. & $\left(\mathrm{g} / \mathrm{cm}^{3}\right)$ & & & $\mathrm{m}^{2} \times \mathrm{k} . \mathrm{y}$ & \\
\hline $132-810 \mathrm{C}-$ & & & & & & & & \\
\hline $1 \mathrm{H}-1,17.5$ & 0.17 & 0.035 & 0.482 & 0.80 & 0.386 & 0.253 & 0.132 & 0.075 \\
\hline $1 \mathrm{H}-1,23.5$ & 0.23 & 0.048 & 0.482 & 0.78 & 0.376 & 0.230 & 0.146 & \\
\hline $1 \mathrm{H}-1,29.5$ & 0.29 & 0.060 & 0.482 & 0.77 & 0.371 & 0.230 & 0.141 & \\
\hline IH-1, 35.7 & 0.36 & 0.075 & 0.482 & 0.73 & 0.352 & 0.219 & 0.133 & \\
\hline $1 \mathrm{H}-1,41.6$ & 0.42 & 0.086 & 1.257 & 0.73 & 0.918 & 0.522 & 0.396 & \\
\hline $1 \mathrm{H}-1,44.5$ & 0.44 & 0.087 & 1.257 & 0.73 & 0.918 & 0.506 & 0.412 & \\
\hline IH-1, 50.5 & 0.50 & 0.092 & 1.257 & 0.74 & 0.930 & 0.515 & 0.416 & 0.196 \\
\hline $1 \mathrm{H}-1,53.5$ & 0.54 & 0.095 & 1.257 & 0.73 & 0.918 & 0.488 & 0.429 & \\
\hline $1 \mathrm{H}-1,59.5$ & 0.60 & 0.100 & 1.257 & 0.73 & 0.918 & 0.534 & 0.384 & \\
\hline $1 \mathrm{H}-1,65.5$ & 0.65 & 0.104 & 1.257 & 0.81 & 1.018 & 0.582 & 0.436 & \\
\hline 1H-1, 68.6 & 0.69 & 0.107 & 1.257 & 0.72 & 0.905 & 0.562 & 0.343 & \\
\hline $1 \mathrm{H}-1,74.5$ & 0.75 & 0.112 & 1.257 & 0.86 & 1.081 & 0.619 & 0.462 & \\
\hline $1 \mathrm{H}-1,80.5$ & 0.81 & 0.117 & 1.257 & 0.82 & 1.031 & 0.605 & 0.425 & 0.194 \\
\hline $1 \mathrm{H}-1,83.5$ & 0.83 & 0.118 & 1.257 & 0.88 & 1.106 & 0.656 & 0.450 & \\
\hline IH-I, 89.5 & 0.89 & 0.123 & 1.257 & 0.80 & 1.006 & 0.606 & 0.399 & \\
\hline $1 \mathrm{H}-1.95 .5$ & 0.95 & 0.128 & 1.257 & 0.81 & 1.018 & 0.605 & 0.413 & \\
\hline $1 \mathrm{H}-1,98.5$ & 0.99 & 0.131 & 1.257 & 0.73 & 0.918 & 0.559 & 0.358 & \\
\hline $1 \mathrm{H}-1,104.7$ & 1.05 & 0.136 & 1.257 & 0.96 & 1.207 & 0.738 & 0.469 & \\
\hline $1 \mathrm{H}-1,110.6$ & 1.11 & 0.141 & 1.257 & 0.85 & 1.068 & 0.554 & 0.515 & \\
\hline IH-1, 116.6 & 1.17 & 0.146 & 1.257 & 0.84 & 1.056 & 0.538 & 0.518 & 0.192 \\
\hline $1 \mathrm{H}-1,119.5$ & 1.20 & 0.148 & 1.257 & 0.90 & 1.131 & 0.672 & 0.459 & \\
\hline $1 \mathrm{H}-1,125.5$ & 1.25 & 0.152 & 1.257 & 0.83 & 1.043 & 0.657 & 0.386 & \\
\hline $1 \mathrm{H}-1,128.5$ & 1.28 & 0.154 & 1.257 & 0.94 & 1.182 & 0.702 & 0.480 & \\
\hline IH- $1,134.5$ & 1.35 & 0.160 & 1.257 & 0.94 & 1.182 & 0.778 & 0.404 & 0.134 \\
\hline $1 \mathrm{H}-1,140.5$ & 1.40 & 0.164 & 1.257 & 0.80 & 1.006 & 0.608 & 0.398 & \\
\hline $1 \mathrm{H}-1,146.5$ & 1.47 & 0.169 & 1.257 & 0.83 & 1.043 & 0.525 & 0.519 & \\
\hline IH-1, 149.5 & 1.50 & 0.172 & 1.257 & 0.80 & 1.006 & 0.416 & 0.590 & \\
\hline $1 \mathrm{H}-2,5.5$ & 1.55 & 0.176 & 1.257 & 0.79 & 0.993 & 0.513 & 0.480 & 0.190 \\
\hline $1 \mathrm{H}-2,8.5$ & 1.59 & 0.179 & 1.257 & 0.76 & 0.955 & 0.512 & 0.443 & \\
\hline $1 \mathrm{H}-2,17.5$ & 1.67 & 0.185 & 1.257 & 0.75 & 0.943 & 0.496 & 0.447 & \\
\hline $1 \mathrm{H}-2,20.5$ & 1.71 & 0.188 & 1.257 & 0.76 & 0.955 & 0.517 & 0.439 & \\
\hline $1 \mathrm{H}-2,23.5$ & 1.74 & 0.191 & 1.257 & 0.74 & 0.930 & 0.546 & 0.384 & \\
\hline $1 \mathrm{H}-2,29.5$ & 1.79 & 0.195 & 1.257 & 0.80 & 1.006 & 0.615 & 0.391 & \\
\hline $1 \mathrm{H}-2,35.5$ & 1.86 & 0.200 & 1.257 & 0.84 & 1.056 & 0.611 & 0.445 & \\
\hline IH-2, 41.5 & 1.91 & 0.204 & 1.257 & 0.90 & 1.131 & 0.651 & 0.480 & 0.272 \\
\hline $1 \mathrm{H}-2,44.5$ & 1.95 & 0.207 & 1.257 & 0.73 & 0.918 & 0.502 & 0.415 & \\
\hline $1 \mathrm{H}-2,65.5$ & 2.15 & 0.223 & 1.257 & 0.83 & 1.043 & 0.533 & 0.510 & \\
\hline $2 \mathrm{H}-1,5.5$ & 2.46 & 0.248 & 1.257 & 0.83 & 1.043 & 0.413 & 0.630 & 0.203 \\
\hline $2 \mathrm{H}-1,8.5$ & 2.49 & 0.250 & 1.257 & 0.87 & 1.094 & 0.519 & 0.574 & 0.203 \\
\hline $2 \mathrm{H}-1,14.5$ & 2.55 & 0.255 & 1.257 & 0.82 & 1.031 & 0.609 & 0.421 & 0.188 \\
\hline $2 \mathrm{H}-1,20.5$ & 2.61 & 0.260 & 1.517 & 0.84 & 1.274 & 0.786 & 0.489 & 0.209 \\
\hline $2 \mathrm{H}-1,26.5$ & 2.67 & 0.264 & 1.517 & 0.78 & 1.183 & 0.698 & 0.486 & 0.242 \\
\hline $2 \mathrm{H}-1,29.6$ & 2.70 & 0.266 & 1.517 & 0.81 & 1.229 & 0.712 & 0.517 & 0.236 \\
\hline $2 \mathrm{H}-1,35.5$ & 2.76 & 0.270 & 1.517 & 0.82 & 1.244 & 0.586 & 0.658 & 0.282 \\
\hline $2 \mathrm{H}-1,38.5$ & 2.79 & 0.272 & 1.517 & 0.78 & 1.183 & 0.632 & 0.551 & 0.191 \\
\hline $2 \mathrm{H}-1,44.5$ & 2.85 & 0.276 & 1.517 & 0.93 & 1.411 & 0.721 & 0.689 & 0.426 \\
\hline $2 \mathrm{H}-1,50.6$ & 2.91 & 0.280 & 1.517 & 0.90 & 1.365 & 0.926 & 0.439 & 0.217 \\
\hline $2 \mathrm{H}-1,53.5$ & 2.94 & 0.282 & 1.517 & 0.98 & 1.487 & 1.012 & 0.475 & 0.282 \\
\hline $2 \mathrm{H}-1,59.6$ & 3.00 & 0.286 & 1.517 & 0.90 & 1.365 & 0.963 & 0.403 & 0.180 \\
\hline $2 \mathrm{H}-1,65.5$ & 3.06 & 0.290 & 1.517 & 0.87 & 1.320 & 0.887 & 0.432 & 0.210 \\
\hline $2 \mathrm{H}-1,68.5$ & 3.09 & 0.292 & 1.517 & 0.93 & 1.411 & 0.974 & 0.437 & 0.195 \\
\hline $2 \mathrm{H}-1,74.5$ & 3.15 & 0.296 & 1.517 & 0.94 & 1.426 & 0.955 & 0.471 & 0.227 \\
\hline $2 \mathrm{H}-1,80.5$ & 3.21 & 0.299 & 1.517 & 0.93 & 1.411 & 1.107 & 0.304 & \\
\hline $2 \mathrm{H}-1,83.5$ & 3.24 & 0.301 & 1.517 & 0.94 & 1.426 & 1.069 & 0.357 & 0.225 \\
\hline $2 \mathrm{H}-1,89.5$ & 3.30 & 0.306 & 1.517 & 0.90 & 1.365 & 1.062 & 0.303 & 0.181 \\
\hline $2 \mathrm{H}-1,95.6$ & 3.36 & 0.309 & 1.517 & 0.88 & 1.335 & 0.994 & 0.341 & \\
\hline $2 \mathrm{H}-1,98.5$ & 3.39 & 0.311 & 1.517 & 0.83 & 1.259 & 0.827 & 0.432 & 0.211 \\
\hline $2 \mathrm{H}-1,104.5$ & 3.45 & 0.315 & 1.517 & 0.83 & 1.259 & 0.760 & 0.499 & 0.248 \\
\hline $2 \mathrm{H}-1,110.7$ & 3.51 & 0.319 & 1.517 & 0.82 & 1.244 & 0.712 & 0.532 & 0.314 \\
\hline $2 \mathrm{H}-1,113.7$ & 3.54 & 0.321 & 1.517 & 0.90 & 1.365 & 0.770 & 0.595 & 0.292 \\
\hline $2 \mathrm{H}-1,119.5$ & 3.60 & 0.325 & 1.517 & 0.75 & 1.138 & 0.586 & 0.552 & 0.279 \\
\hline $2 \mathrm{H}-1,125.5$ & 3.66 & 0.329 & 1.517 & 0.86 & 1.305 & 0.735 & 0.570 & 0.324 \\
\hline $2 \mathrm{H}-1,128.5$ & 3.69 & 0.331 & 1.517 & 0.87 & 1.320 & 0.702 & 0.618 & 0.370 \\
\hline $2 \mathrm{H}-1,134.5$ & 3.75 & 0.335 & 1.517 & 0.79 & 1.198 & 0.833 & 0.365 & 0.157 \\
\hline $2 \mathrm{H}-1,140.6$ & 3.81 & 0.339 & 1.517 & 0.96 & 1.456 & 0.961 & 0.496 & 0.204 \\
\hline $2 \mathrm{H}-1,143.5$ & 3.84 & 0.341 & 1.517 & 0.90 & 1.365 & 0.883 & 0.482 & 0.184 \\
\hline $2 \mathrm{H}-1,149.5$ & 3.90 & 0.345 & 1.517 & 0.88 & 1.335 & 0.840 & 0.495 & 0.215 \\
\hline $2 \mathrm{H}-2,5.5$ & 3.96 & 0.349 & 1.517 & 0.84 & 1.274 & 0.849 & 0.425 & 0.163 \\
\hline $2 \mathrm{H}-2,8.5$ & 3.99 & 0.351 & 1.517 & 0.84 & 1.274 & 0.860 & 0.414 & 0.160 \\
\hline $2 \mathrm{H}-2,14.5$ & 4.05 & 0.355 & 1.517 & 0.87 & 1.320 & 0.842 & 0.478 & 0.229 \\
\hline $2 \mathrm{H}-2,20.5$ & 4.11 & 0.359 & 1.517 & 0.93 & 1.411 & 0.983 & 0.428 & 0.207 \\
\hline $2 \mathrm{H}-2,26.5$ & 4.16 & 0.362 & 1.517 & 0.88 & 1.335 & 0.944 & 0.391 & 0.175 \\
\hline $2 \mathrm{H}-2,29.5$ & 4.20 & 0.365 & 1.517 & 0.92 & 1.396 & 0.904 & 0.492 & 0.240 \\
\hline $2 \mathrm{H}-2,35.5$ & 4.26 & 0.369 & 1.517 & 0.90 & 1.365 & 0.902 & 0.464 & 0.195 \\
\hline $2 \mathrm{H}-2,38.5$ & 4.29 & 0.371 & 1.517 & 0.88 & 1.335 & 0.867 & 0.468 & 0.253 \\
\hline $2 \mathrm{H}-2,44.5$ & 4.35 & 0.375 & 1.517 & 0.83 & 1.259 & 0.964 & 0.295 & \\
\hline $2 \mathrm{H}-2,50.6$ & 4.41 & 0.379 & 1.517 & 0.86 & 1.305 & 1.094 & 0.211 & \\
\hline $2 \mathrm{H}-2,53.6$ & 4.44 & 0.381 & 1.517 & 0.86 & 1.305 & 1.101 & 0.204 & 0.132 \\
\hline $2 \mathrm{H}-2,59.5$ & 4.50 & 0.385 & 1.517 & 0.90 & 1.365 & 1.160 & 0.205 & 0.137 \\
\hline $2 \mathrm{H}-2,65.5$ & 4.56 & 0.389 & 1.517 & 0.91 & 1.380 & 1.202 & 0.179 & 0.129 \\
\hline $2 \mathrm{H}-2,68.6$ & 4.59 & 0.391 & 1.517 & 0.96 & 1.456 & 1.193 & 0.263 & 0.213 \\
\hline $2 \mathrm{H}-2,74.5$ & 4.64 & 0.394 & 1.517 & 0.84 & 1.274 & 1.085 & 0.189 & 0.133 \\
\hline $2 \mathrm{H}-2,80.5$ & 4.70 & 0.398 & 1.517 & 0.87 & 1.320 & 1.119 & 0.200 & \\
\hline $2 \mathrm{H}-2,83.5$ & 4.74 & 0.400 & 1.517 & 0.91 & 1.380 & 1.173 & 0.208 & 0.139 \\
\hline $2 \mathrm{H}-2,89.5$ & 4.80 & 0.404 & 1.517 & 0.83 & 1.259 & 1.039 & 0.220 & 0.156 \\
\hline $2 \mathrm{H}-2,95.5$ & 4.86 & 0.408 & 1.517 & 0.76 & 1.153 & 0.980 & 0.173 & 0.110 \\
\hline $2 \mathrm{H}-2,101.6$ & 4.92 & 0.412 & 1.517 & 0.85 & 1.289 & 1.041 & 0.248 & 0.179 \\
\hline
\end{tabular}


APPENDIX C (continued).

\begin{tabular}{|c|c|c|c|c|c|}
\hline Core, section, & Depth & & & & MAR \\
\hline interval $(\mathrm{cm})$ & (mbsf) & (Ma) & (cm/k.y.) & $\left(\mathrm{g} / \mathrm{cm}^{3}\right)$ & \\
\hline $2 \mathrm{H}-2,104.5$ & 4.95 & 0.414 & 1.517 & 0.89 & 1.350 \\
\hline $2 \mathrm{H}-2,110.5$ & 5.01 & 0.418 & 1.517 & 0.85 & 1.289 \\
\hline $2 \mathrm{H}-2,116.6$ & 5.07 & 0.422 & 1.517 & 0.99 & 1.502 \\
\hline $2 \mathrm{H}-2,119.7$ & 5.10 & 0.424 & 1.517 & 0.83 & 1.259 \\
\hline $2 \mathrm{H}-2,125.5$ & 5.16 & 0.428 & 1.517 & 0.93 & 1.411 \\
\hline $2 \mathrm{H}-2,131.5$ & 5.22 & 0.432 & 1.517 & 0.88 & 1.335 \\
\hline $2 \mathrm{H}-2,134.5$ & 5.25 & 0.434 & 1.517 & 0.83 & 1.259 \\
\hline $2 \mathrm{H}-2,140.7$ & 5.31 & 0.438 & 1.517 & 0.80 & 1.214 \\
\hline $2 \mathrm{H}-2,146.6$ & 5.37 & 0.442 & 1.517 & 0.81 & 1.229 \\
\hline $2 \mathrm{H}-3,5.5$ & 5.45 & 0.447 & 1.517 & 0.82 & 1.244 \\
\hline $2 \mathrm{H}-3,11.5$ & 5.51 & 0.451 & 1.517 & 0.81 & 1.229 \\
\hline $2 \mathrm{H}-3,14.5$ & 5.55 & 0.454 & 1.517 & 0.78 & 1.183 \\
\hline $2 \mathrm{H}-3,20.5$ & 5.61 & 0.458 & 1.517 & 0.82 & 1.244 \\
\hline $2 \mathrm{H}-3,26.5$ & 5.66 & 0.461 & 3.806 & 0.81 & 3.083 \\
\hline $2 \mathrm{H}-3,29.5$ & 5.70 & 0.462 & 3.806 & 0.80 & 3.045 \\
\hline $2 \mathrm{H}-3,35.5$ & 5.76 & 0.464 & 3.806 & 0.83 & 3.159 \\
\hline $2 \mathrm{H}-3,41.5$ & 5.82 & 0.465 & 3.806 & 0.80 & 3.045 \\
\hline $2 \mathrm{H}-3,44.6$ & 5.85 & 0.466 & 3.806 & 0.82 & 3.121 \\
\hline $2 \mathrm{H}-3,50.5$ & 5.91 & 0.468 & 3.806 & 0.85 & 3.235 \\
\hline $2 \mathrm{H}-3,56.5$ & 5.97 & 0.469 & 3.806 & 0.81 & 3.083 \\
\hline $2 \mathrm{H}-3,59.5$ & 6.00 & 0.470 & 3.806 & 0.84 & 3.197 \\
\hline $2 \mathrm{H}-3,65.5$ & 6.06 & 0.472 & 3.806 & 0.85 & 3.235 \\
\hline $2 \mathrm{H}-3,71.5$ & 6.12 & 0.473 & 3.806 & 0.88 & 3.349 \\
\hline $2 \mathrm{H}-3,74.6$ & 6.15 & 0.474 & 3.806 & 0.96 & 3.654 \\
\hline $2 \mathrm{H}-3,80.5$ & 6.20 & 0.475 & 3.806 & 0.85 & 3.235 \\
\hline $2 \mathrm{H}-3,86.5$ & 6.27 & 0.477 & 3.806 & 0.98 & 3.730 \\
\hline $2 \mathrm{H}-3,95.5$ & 6.36 & 0.479 & 3.806 & 0.90 & 3.425 \\
\hline $2 \mathrm{H}-3,101.6$ & 6.42 & 0.481 & 3.806 & 0.88 & 3.349 \\
\hline $2 \mathrm{H}-3,104.6$ & 6.45 & 0.482 & 3.806 & 0.90 & 3.425 \\
\hline $2 \mathrm{H}-3,110.6$ & 6.51 & 0.483 & 3.806 & 0.91 & 3.463 \\
\hline $2 \mathrm{H}-3,116.5$ & 6.57 & 0.485 & 3.806 & 1.01 & 3.844 \\
\hline $2 \mathrm{H}-3,119.5$ & 6.60 & 0.486 & 3.806 & 0.84 & 3.197 \\
\hline $2 \mathrm{H}-3,125.7$ & 6.66 & 0.487 & 3.806 & 0.84 & 3.197 \\
\hline $2 \mathrm{H}-3,131.6$ & 6.72 & 0.489 & 3.806 & 0.90 & 3.425 \\
\hline $2 \mathrm{H}-3,134.6$ & 6.75 & 0.490 & 3.806 & 0.94 & 3.578 \\
\hline $2 \mathrm{H}-3,140.7$ & 6.81 & 0.491 & 3.806 & 1.00 & 3.806 \\
\hline $2 \mathrm{H}-3,146.5$ & 6.87 & 0.493 & 3.806 & 0.94 & 3.578 \\
\hline $2 \mathrm{H}-4,2.5$ & 6.93 & 0.494 & 3.806 & 0.93 & 3.540 \\
\hline $2 \mathrm{H}-4,5.5$ & 6.95 & 0.495 & 3.806 & 0.88 & 3.349 \\
\hline $2 \mathrm{H}-4,11.5$ & 7.01 & 0.496 & 3.806 & 0.91 & 3.463 \\
\hline $2 \mathrm{H}-4,14.6$ & 7.05 & 0.498 & 3.806 & 0.93 & 3.540 \\
\hline $2 \mathrm{H}-4,20.5$ & 7.11 & 0.499 & 3.806 & 0.88 & 3.349 \\
\hline $2 \mathrm{H}-4,26.5$ & 7.16 & 0.500 & 3.806 & 0.91 & 3.463 \\
\hline $2 \mathrm{H}-4,29.5$ & 7.20 & 0.502 & 3.806 & 0.93 & 3.540 \\
\hline $2 \mathrm{H}-4,35.5$ & 7.26 & 0.503 & 3.806 & 0.96 & 3.654 \\
\hline $2 \mathrm{H}-4,41.5$ & 7.32 & 0.505 & 3.806 & 0.90 & 3.425 \\
\hline $2 \mathrm{H}-4,44.6$ & 7.35 & 0.505 & 3.806 & 0.98 & 3.730 \\
\hline $2 \mathrm{H}-4,50.6$ & 7.41 & 0.507 & 3.806 & 0.95 & 3.616 \\
\hline $2 \mathrm{H}-4,56.5$ & 7.47 & 0.509 & 3.806 & 0.96 & 3.654 \\
\hline $2 \mathrm{H}-4,59.5$ & 7.50 & 0.509 & 3.806 & 0.88 & 3.349 \\
\hline $2 \mathrm{H}-4,65.5$ & 7.56 & 0.511 & 3.806 & 0.93 & 3.540 \\
\hline $2 \mathrm{H}-4,68.5$ & 7.59 & 0.512 & 3.806 & 0.98 & 3.730 \\
\hline $2 \mathrm{H}-4,74.5$ & 7.64 & 0.513 & 3.806 & 0.98 & 3.730 \\
\hline $2 \mathrm{H}-4,80.6$ & 7.71 & 0.515 & 3.806 & 1.01 & 3.844 \\
\hline $2 \mathrm{H}-4,86.6$ & 7.77 & 0.516 & 3.806 & 0.98 & 3.730 \\
\hline $2 \mathrm{H}-4,89.6$ & 7.80 & 0.517 & 3.806 & 0.94 & 3.578 \\
\hline $2 \mathrm{H}-4,95.6$ & 7.86 & 0.519 & 3.806 & 0.98 & 3.730 \\
\hline $2 \mathrm{H}-4,101.5$ & 7.91 & 0.520 & 3.806 & 0.96 & 3.654 \\
\hline $2 \mathrm{H}-4,104.5$ & 7.95 & 0.521 & 3.806 & 0.95 & 3.616 \\
\hline $2 \mathrm{H}-4,110.7$ & 8.01 & 0.523 & 3.806 & 0.91 & 3.463 \\
\hline $2 \mathrm{H}-4,116.5$ & 8.07 & 0.524 & 3.806 & 0.99 & 3.768 \\
\hline $2 \mathrm{H}-4,119.6$ & 8.10 & 0.525 & 3.806 & 0.93 & 3.540 \\
\hline $2 \mathrm{H}-4,125.5$ & 8.15 & 0.526 & 3.806 & 1.05 & 3.996 \\
\hline $2 \mathrm{H}-4,131.5$ & 8.22 & 0.528 & 3.806 & 0.98 & 3.730 \\
\hline $2 \mathrm{H}-4,134.5$ & 8.24 & 0.529 & 3.806 & 1.05 & 3.996 \\
\hline $2 \mathrm{H}-4,140.6$ & 8.31 & 0.531 & 3.806 & 0.94 & 3.578 \\
\hline $2 \mathrm{H}-4,146.5$ & 8.36 & 0.532 & 3.806 & 0.99 & 3.768 \\
\hline $2 \mathrm{H}-4,149.5$ & 8.40 & 0.533 & 3.806 & 0.91 & 3.463 \\
\hline $2 \mathrm{H}-5,5.5$ & 8.45 & 0.534 & 3.806 & 0.93 & 3.540 \\
\hline $2 \mathrm{H}-5,11.5$ & 8.51 & 0.536 & 3.806 & 0.96 & 3.654 \\
\hline $2 \mathrm{H}-5,14.5$ & 8.55 & 0.537 & 3.806 & 0.98 & 3.730 \\
\hline $2 \mathrm{H}-5,20.5$ & 8.60 & 0.538 & 3.806 & 0.98 & 3.730 \\
\hline $2 \mathrm{H}-5,26.5$ & 8.66 & 0.540 & 3.806 & 0.99 & 3.768 \\
\hline $2 \mathrm{H}-5,29.5$ & 8.69 & 0.541 & 3.806 & 1.05 & 3.996 \\
\hline $2 \mathrm{H}-5,35.5$ & 8.75 & 0.542 & 3.806 & 1.01 & 3.844 \\
\hline $2 \mathrm{H}-5,41.6$ & 8.82 & 0.544 & 3.806 & 1.01 & 3.844 \\
\hline $2 \mathrm{H}-5,44.5$ & 8.84 & 0.545 & 3.806 & 0.98 & 3.730 \\
\hline $2 \mathrm{H}-5,50.5$ & 8.90 & 0.546 & 3.806 & 0.98 & 3.730 \\
\hline $2 \mathrm{H}-5,56.6$ & 8.97 & 0.548 & 3.806 & 1.01 & 3.844 \\
\hline $2 \mathrm{H}-5,59.6$ & 9.00 & 0.549 & 3.806 & 0.96 & 3.654 \\
\hline $2 \mathrm{H}-5,65.5$ & 9.05 & 0.550 & 3.806 & 0.94 & 3.578 \\
\hline $2 \mathrm{H}-5,71.6$ & 9.12 & 0.552 & 3.806 & 1.01 & 3.844 \\
\hline $2 \mathrm{H}-5,74.5$ & 9.14 & 0.552 & 3.806 & 0.98 & 3.730 \\
\hline $2 \mathrm{H}-5,80.6$ & 9.21 & 0.554 & 3.806 & 0.90 & 3.425 \\
\hline $2 \mathrm{H}-5,86.5$ & 9.26 & 0.556 & 3.806 & 0.94 & 3.578 \\
\hline $2 \mathrm{H}-5,89.5$ & 9.30 & 0.557 & 3.806 & 0.91 & 3.463 \\
\hline $2 \mathrm{H}-5,95.6$ & 9.36 & 0.558 & 3.806 & 0.93 & 3.540 \\
\hline $2 \mathrm{H}-5,101.5$ & 9.41 & 0.559 & 3.806 & 0.91 & 3.463 \\
\hline $2 \mathrm{H}-5,104.6$ & 9.45 & 0.561 & 3.806 & 0.95 & 3.616 \\
\hline $2 \mathrm{H}-5,110.5$ & 9.51 & 0.562 & 3.806 & 0.88 & 3.349 \\
\hline $2 \mathrm{H}-5,116.5$ & 9.56 & 0.563 & 3.806 & 0.93 & 3.540 \\
\hline
\end{tabular}


APPENDIX C (continued).

\begin{tabular}{|c|c|c|c|c|c|}
\hline Core, section, & Depth & Age & LSR & DBD & MAR \\
\hline interval $(\mathrm{cm})$ & (mbsf) & (Ma) & $(\mathrm{cm} / \mathrm{k} . \mathrm{y})$. & $\left(\mathrm{g} / \mathrm{cm}^{3}\right)$ & \\
\hline $2 \mathrm{H}-5,119.5$ & 9.59 & 0.564 & 3.806 & 0.96 & 3.654 \\
\hline $2 \mathrm{H}-5,125.6$ & 9.66 & 0.566 & 3.806 & 0.93 & 3.540 \\
\hline $2 \mathrm{H}-5,131.5$ & 9.72 & 0.568 & 3.806 & 0.93 & 3.540 \\
\hline $2 \mathrm{H}-5,134.5$ & 9.74 & 0.568 & 3.806 & 0.90 & 3.425 \\
\hline $2 \mathrm{H}-5,140.5$ & 9.80 & 0.570 & 3.806 & 1.08 & 4.110 \\
\hline $2 \mathrm{H}-5,146.5$ & 9.86 & 0.571 & 3.806 & 0.90 & 3.425 \\
\hline $2 \mathrm{H}-5,149.5$ & 9.89 & 0.572 & 3.806 & 0.93 & 3.540 \\
\hline $2 \mathrm{H}-6,5.5$ & 9.95 & 0.574 & 3.806 & 0.91 & 3.463 \\
\hline $2 \mathrm{H}-6,11.5$ & 10.01 & 0.575 & 3.806 & 0.85 & 3.235 \\
\hline $2 \mathrm{H}-6,14.5$ & 10.05 & 0.576 & 3.806 & 0.80 & 3.045 \\
\hline $2 \mathrm{H}-6,20.5$ & 10.10 & 0.578 & 3.806 & 0.85 & 3.235 \\
\hline $2 \mathrm{H}-6,26.6$ & 10.17 & 0.580 & 3.806 & 0.83 & 3.159 \\
\hline $2 \mathrm{H}-6,29.5$ & 10.19 & 0.580 & 3.806 & 0.82 & 3.121 \\
\hline $2 \mathrm{H}-6,35.6$ & 10.26 & 0.582 & 3.806 & 0.84 & 3.197 \\
\hline $2 \mathrm{H}-6,41.6$ & 10.32 & 0.583 & 3.806 & 0.84 & 3.197 \\
\hline $2 \mathrm{H}-6,44.5$ & 10.34 & 0.584 & 3.806 & 0.84 & 3.197 \\
\hline $2 \mathrm{H}-6,50.5$ & 10.40 & 0.586 & 3.806 & 0.83 & 3.159 \\
\hline $2 \mathrm{H}-6,56.6$ & 10.47 & 0.587 & 3.806 & 0.82 & 3.121 \\
\hline $2 \mathrm{H}-6,59.5$ & 10.49 & 0.588 & 3.806 & 0.81 & 3.083 \\
\hline $2 \mathrm{H}-6,65.5$ & 10.55 & 0.590 & 3.806 & 0.90 & 3.425 \\
\hline $2 \mathrm{H}-6,71.5$ & 10.61 & 0.591 & 3.806 & 0.88 & 3.349 \\
\hline $2 \mathrm{H}-6,74.5$ & 10.64 & 0.592 & 3.806 & 0.88 & 3.349 \\
\hline $2 \mathrm{H}-6,80.5$ & 10.70 & 0.593 & 3.806 & 0.85 & 3.235 \\
\hline $2 \mathrm{H}-6,86.5$ & 10.76 & 0.595 & 3.806 & 0.94 & 3.578 \\
\hline $2 \mathrm{H}-6,89.5$ & 10.80 & 0.596 & 3.806 & 1.03 & 3.920 \\
\hline $2 \mathrm{H}-6,95.6$ & 10.86 & 0.598 & 3.806 & 0.99 & 3.768 \\
\hline $2 \mathrm{H}-6,101.6$ & 10.92 & 0.599 & 3,806 & 0.94 & 3.578 \\
\hline $2 \mathrm{H}-6,104.6$ & 10.95 & 0.600 & 3.806 & 0.89 & 3.387 \\
\hline $2 \mathrm{H}-6,110.6$ & 11.01 & 0.602 & 3.806 & 0.94 & 3.578 \\
\hline $2 \mathrm{H}-6,116.7$ & 11.07 & 0.603 & 3.806 & 0.78 & 2.969 \\
\hline $2 \mathrm{H}-6,119.7$ & 11.10 & 0.604 & 3.806 & 0.93 & 3.540 \\
\hline $2 \mathrm{H}-6,125.5$ & 11.15 & 0.605 & 3.806 & 0.84 & 3.197 \\
\hline $2 \mathrm{H}-6,134.6$ & 11.25 & 0.608 & 3.806 & 0.88 & 3.349 \\
\hline $2 \mathrm{H}-6,140.5$ & 11.30 & 0.609 & 3.806 & 1.05 & 3.996 \\
\hline $2 \mathrm{H}-6,146.6$ & 11.37 & 0.611 & 3.806 & 0.93 & 3.540 \\
\hline $2 \mathrm{H}-6,149.5$ & 11.39 & 0.612 & 3.806 & 0.98 & 3.730 \\
\hline $2 \mathrm{H}-7,5.5$ & 11.45 & 0.613 & 3.806 & 0.85 & 3.235 \\
\hline $2 \mathrm{H}-7,8.5$ & 11.48 & 0.614 & 3.806 & 0.93 & 3.540 \\
\hline $2 \mathrm{H}-7,14.5$ & 11.55 & 0.616 & 3.806 & 0.96 & 3.654 \\
\hline $2 \mathrm{H}-7,20.5$ & 11.60 & 0.617 & 3.806 & 0.93 & 3.540 \\
\hline $2 \mathrm{H}-7,26.5$ & 11.66 & 0.619 & 3.806 & 0.90 & 3.425 \\
\hline $2 \mathrm{H}-7,29.5$ & 11.69 & 0.619 & 3.806 & 0.91 & 3.463 \\
\hline $2 \mathrm{H}-7,35.5$ & 11.75 & 0.621 & 3.806 & 0.90 & 3.425 \\
\hline $2 \mathrm{H}-7,41.5$ & 11.81 & 0.623 & 3.806 & 0.89 & 3.387 \\
\hline $2 \mathrm{H}-7,44.5$ & 11.84 & 0.623 & 3.806 & 0.86 & 3.273 \\
\hline $2 \mathrm{H}-7,50.5$ & 11.90 & 0.625 & 3.806 & 0.88 & 3.349 \\
\hline $3 \mathrm{H}-1,5.5$ & 11.95 & 0.626 & 3.806 & 0.87 & 3.311 \\
\hline $3 \mathrm{H}-1,11.5$ & 12.01 & 0.628 & 3.806 & 0.88 & 3.349 \\
\hline $3 \mathrm{H}-1,14.5$ & 12.05 & 0.629 & 3.806 & 0.98 & 3.730 \\
\hline $3 \mathrm{H}-1,20.5$ & 12.10 & 0.630 & 3.806 & 0.93 & 3.540 \\
\hline $3 \mathrm{H}-1,26.5$ & 12.16 & 0.632 & 3.806 & 0.96 & 3.654 \\
\hline $3 \mathrm{H}-1,29.5$ & 12.19 & 0.633 & 3.806 & 0.93 & 3.540 \\
\hline $3 \mathrm{H}-1,35.5$ & 12.25 & 0.634 & 3.806 & 0.96 & 3.654 \\
\hline $3 \mathrm{H}-1,41.5$ & 12.31 & 0.636 & 3.806 & 0.87 & 3.311 \\
\hline $3 \mathrm{H}-1,44.5$ & 12.34 & 0.637 & 3.806 & 0.83 & 3.159 \\
\hline $3 \mathrm{H}-1,50.6$ & 12.41 & 0.638 & 3.806 & 0.72 & 2.740 \\
\hline $3 \mathrm{H}-1,56.5$ & 12.46 & 0.640 & 3.806 & 0.90 & 3.425 \\
\hline $3 \mathrm{H}-1,65.5$ & 12.55 & 0.642 & 3.806 & 0.82 & 3.121 \\
\hline $3 \mathrm{H}-1,71.5$ & 12.61 & 0.644 & 3.806 & 0.83 & 3.159 \\
\hline $3 \mathrm{H}-1,74.6$ & 12.65 & 0.645 & 3.806 & 0.77 & 2.931 \\
\hline $3 \mathrm{H}-1,80.5$ & 12.70 & 0.646 & 3.806 & 0.82 & 3.121 \\
\hline $3 \mathrm{H}-1,86.5$ & 12.76 & 0.648 & 3.806 & 0.87 & 3.311 \\
\hline $3 \mathrm{H}-1,95.6$ & 12.86 & 0.650 & 3.806 & 0.87 & 3.311 \\
\hline $3 \mathrm{H}-1,101.6$ & 12.92 & 0.652 & 3.806 & 0.91 & 3.463 \\
\hline $3 \mathrm{H}-1,104.7$ & 12.95 & 0.653 & 3.806 & 0.96 & 3.654 \\
\hline $3 \mathrm{H}-1,110.6$ & 13.01 & 0.654 & 3.806 & 0.93 & 3.540 \\
\hline $3 \mathrm{H}-1,116.6$ & 13.07 & 0.656 & 3.806 & 0.84 & 3.197 \\
\hline $3 \mathrm{H}-1,119.5$ & 13.09 & 0.656 & 3.806 & 0.99 & 3.768 \\
\hline $3 \mathrm{H}-1,125,5$ & 13.15 & 0.658 & 3.806 & 1.04 & 3.958 \\
\hline $3 \mathrm{H}-1,131.7$ & 13.22 & 0.660 & 3.806 & 0.90 & 3.425 \\
\hline $3 \mathrm{H}-1,134.5$ & 13.24 & 0.660 & 3.806 & 0.93 & 3.540 \\
\hline $3 \mathrm{H}-1,140.5$ & 13.30 & 0.662 & 3.806 & 0.96 & 3.654 \\
\hline $3 \mathrm{H}-1,146.6$ & 13.37 & 0.664 & 3.806 & 0.83 & 3.159 \\
\hline $3 \mathrm{H}-2,5.7$ & 13.46 & 0.666 & 3.806 & 0.98 & 3.730 \\
\hline $3 \mathrm{H}-2,11.7$ & 13.52 & 0.668 & 3.806 & 0.98 & 3.730 \\
\hline $3 \mathrm{H}-2,14.5$ & 13.55 & 0.668 & 3.806 & 1.01 & 3.844 \\
\hline $3 \mathrm{H}-2,20.5$ & 13.60 & 0.670 & 3.806 & 0.99 & 3.768 \\
\hline $3 \mathrm{H}-2,26.5$ & 13.66 & 0.671 & 3.806 & 0.99 & 3.768 \\
\hline $3 \mathrm{H}-2,35.5$ & 13.75 & 0.674 & 3.806 & 0.93 & 3.540 \\
\hline $3 \mathrm{H}-2,41.5$ & 13.81 & 0.675 & 3.806 & 1.01 & 3.844 \\
\hline $3 \mathrm{H}-2,44.5$ & 13.84 & 0.676 & 3.806 & 0.98 & 3.730 \\
\hline $3 \mathrm{H}-2,50.5$ & 13.90 & 0.678 & 3.806 & 0.90 & 3.425 \\
\hline $3 \mathrm{H}-2,56.5$ & 13.96 & 0.679 & 3.806 & 0.98 & 3.730 \\
\hline $3 \mathrm{H}-2,59.5$ & 13.99 & 0.680 & 3.806 & 1.09 & 4.149 \\
\hline $3 \mathrm{H}-2,65.5$ & 14.05 & 0.682 & 3.806 & 1.01 & 3.844 \\
\hline $3 \mathrm{H}-2,71.6$ & 14.12 & 0.683 & 3.806 & 0.93 & 3.540 \\
\hline $3 \mathrm{H}-2,74.7$ & 14.15 & 0.684 & 3.806 & 1.03 & 3.920 \\
\hline $3 \mathrm{H}-2,80.5$ & 14.20 & 0.685 & 3.806 & 0.98 & 3.730 \\
\hline $3 \mathrm{H}-2,86.6$ & 14.27 & 0.687 & 3.806 & 1.03 & 3.920 \\
\hline $3 \mathrm{H}-2,89.6$ & 14.30 & 0.688 & 3.806 & 0.94 & 3.578 \\
\hline & & & & & \\
\hline
\end{tabular}


APPENDIX C (continued).

\begin{tabular}{|c|c|c|c|c|c|}
\hline ction, & Depth & Age & & & MAR \\
\hline interval $(\mathrm{cm})$ & (mbsf) & (Ma) & $(\mathrm{cm} / \mathrm{k} . \mathrm{y})$. & $\left(\mathrm{g} / \mathrm{cm}^{3}\right)$ & \\
\hline $3 \mathrm{H}-2,101.6$ & 14.42 & 0.691 & 3.806 & 1.01 & 3.844 \\
\hline $3 \mathrm{H}-2,104.6$ & 14.45 & 0.692 & 3.806 & 0.94 & 3.578 \\
\hline $3 \mathrm{H}-2,110.7$ & 14.51 & 0.693 & 3.806 & 1.01 & 3.844 \\
\hline $3 \mathrm{H}-2,116.6$ & 14.57 & 0.695 & 3.806 & 1.05 & 3.996 \\
\hline $3 \mathrm{H}-2,119.5$ & 14.59 & 0.696 & 3.806 & 0.96 & 3.654 \\
\hline $3 \mathrm{H}-2,125.5$ & 14.65 & 0.697 & 3.806 & 0.90 & 3.425 \\
\hline $3 \mathrm{H}-2,131.5$ & 14.72 & 0.699 & 3.806 & 0.96 & 3.654 \\
\hline $3 \mathrm{H}-2,134.5$ & 14.74 & 0.700 & 3.806 & 0.94 & 3.578 \\
\hline $3 \mathrm{H}-2,140.5$ & 14.80 & 0.701 & 3.806 & 0.87 & 3.311 \\
\hline $3 \mathrm{H}-2,146.5$ & 14.86 & 0.703 & 3.806 & 0.94 & 3.578 \\
\hline $3 \mathrm{H}-3,5.7$ & 14.96 & 0.705 & 3.806 & 0.88 & 3.349 \\
\hline $3 \mathrm{H}-3,11.5$ & 15.01 & 0.707 & 3.806 & 0.94 & 3.578 \\
\hline $3 \mathrm{H}-3,14.6$ & 15.05 & 0.708 & 3.806 & 0.99 & 3.768 \\
\hline $3 \mathrm{H}-3,20.5$ & 15.10 & 0.709 & 3.806 & 0.93 & 3.540 \\
\hline $3 \mathrm{H}-3,26.5$ & 15.16 & 0.711 & 3.806 & 0.81 & 3.083 \\
\hline $3 \mathrm{H}-3,29.5$ & 15.19 & 0.711 & 3.806 & 0.94 & 3.578 \\
\hline $3 \mathrm{H}-3,35.5$ & 15.25 & 0.713 & 3.806 & 1.09 & 4.149 \\
\hline $3 \mathrm{H}-3,41.6$ & 15.32 & 0.715 & 3.806 & 0.91 & 3.463 \\
\hline $3 \mathrm{H}-3,44.5$ & 15.34 & 0.715 & 3.806 & 0.87 & 3.311 \\
\hline $3 \mathrm{H}-3,50.6$ & 15.41 & 0.717 & 3.806 & 0.88 & 3.349 \\
\hline $3 \mathrm{H}-3,56.5$ & 15.46 & 0.719 & 3.806 & 0.99 & 3.768 \\
\hline $3 \mathrm{H}-3,59.5$ & 15.49 & 0.719 & 3.806 & 0.96 & 3.654 \\
\hline $3 \mathrm{H}-3,65.5$ & 15.55 & 0.721 & 3.806 & 1.03 & 3.920 \\
\hline $3 \mathrm{H}-3,71.5$ & 15.61 & 0.723 & 3.806 & 1.01 & 3.844 \\
\hline $3 \mathrm{H}-3,74.6$ & 15.65 & 0.724 & 3.806 & 0.92 & 3.502 \\
\hline $3 \mathrm{H}-3,80.6$ & 15.71 & 0.725 & 3.806 & 0.87 & 3.311 \\
\hline $3 \mathrm{H}-3,86.6$ & 15.77 & 0.727 & 3.806 & 0.84 & 3.197 \\
\hline $3 \mathrm{H}-3,89.5$ & 15.80 & 0.727 & 3.806 & 0.90 & 3.425 \\
\hline $3 \mathrm{H}-3,95.5$ & 15.85 & 0.729 & 3.806 & 0.82 & 3.121 \\
\hline $3 \mathrm{H}-3,101.5$ & 15.91 & 0.730 & 3.806 & 0.80 & 3.045 \\
\hline $3 \mathrm{H}-3,104.6$ & 15.95 & 0.731 & 3.806 & 0.80 & 3.045 \\
\hline $3 \mathrm{H}-3,110.5$ & 16.00 & 0.733 & 3.806 & 0.80 & 3.045 \\
\hline $3 \mathrm{H}-3,116.6$ & 16.07 & 0.734 & 3.806 & 0.83 & 3.159 \\
\hline $3 \mathrm{H}-3,119.5$ & 16.09 & 0.735 & 3.806 & 0.99 & 3.768 \\
\hline $3 \mathrm{H}-3,125.6$ & 16.16 & 0.737 & 3.806 & 0.93 & 3.540 \\
\hline $3 \mathrm{H}-3,131.6$ & 16.22 & 0.738 & 3.806 & 0.91 & 3.463 \\
\hline $3 \mathrm{H}-3,134.5$ & 16.24 & 0.739 & 3.806 & 0.93 & 3.540 \\
\hline $3 \mathrm{H}-3,140.5$ & 16.31 & 0.741 & 3.806 & 0.96 & 3.654 \\
\hline $3 \mathrm{H}-3,146.5$ & 16.36 & 0.742 & 3.806 & 0.88 & 3.349 \\
\hline $3 \mathrm{H}-4,5.5$ & 16.45 & 0.744 & 3.806 & 0.91 & 3.463 \\
\hline $3 \mathrm{H}-4,11.5$ & 16.51 & 0.746 & 3.806 & 0.90 & 3.425 \\
\hline $3 \mathrm{H}-4,14.5$ & 16.55 & 0.747 & 3.806 & 0.82 & 3.121 \\
\hline $3 \mathrm{H}-4,20.6$ & 16.61 & 0.749 & 3.806 & 0.85 & 3.235 \\
\hline $3 \mathrm{H}-4,26.5$ & 16.66 & 0.750 & 3.806 & 0.96 & 3.654 \\
\hline $3 \mathrm{H}-4,29.5$ & 16.69 & 0.751 & 3.806 & 0.88 & 3.349 \\
\hline $3 \mathrm{H}-4,41.5$ & 16.82 & 0.754 & 3.806 & 0.94 & 3.578 \\
\hline $3 \mathrm{H}-4,44.6$ & 16.85 & 0.755 & 3.806 & 0.94 & 3.578 \\
\hline $3 \mathrm{H}-4,50.6$ & 16.91 & 0.757 & 3.806 & 0.94 & 3.578 \\
\hline $3 \mathrm{H}-4,56.5$ & 16.97 & 0.758 & 3.806 & 0.94 & 3.578 \\
\hline $3 \mathrm{H}-4,59.5$ & 16.99 & 0.759 & 3.806 & 0.84 & 3.197 \\
\hline $3 \mathrm{H}-4,65.5$ & 17.06 & 0.761 & 3.806 & 0.96 & 3.654 \\
\hline $3 \mathrm{H}-4,71.7$ & 17.12 & 0.762 & 3.806 & 0.88 & 3.349 \\
\hline $3 \mathrm{H}-4,74.6$ & 17.15 & 0.763 & 3.806 & 0.84 & 3.197 \\
\hline $3 \mathrm{H}-4,80.5$ & 17.20 & 0.764 & 3.806 & 0.93 & 3.540 \\
\hline $3 \mathrm{H}-4,86.5$ & 17.26 & 0.766 & 3.806 & 0.85 & 3.235 \\
\hline $3 \mathrm{H}-4,89.5$ & 17.30 & 0.767 & 3.806 & 0.97 & 3.692 \\
\hline $3 \mathrm{H}-4,95.5$ & 17.35 & 0.768 & 3.806 & 0.90 & 3.425 \\
\hline $3 \mathrm{H}-4,101.6$ & 17.42 & 0.770 & 3.806 & 1.06 & 4.034 \\
\hline $3 \mathrm{H}-4,104.7$ & 17.45 & 0.771 & 3.806 & 0.98 & 3.730 \\
\hline $3 \mathrm{H}-4,110.5$ & 17.50 & 0.772 & 3.806 & 0.99 & 3.768 \\
\hline $3 \mathrm{H}-4,116.7$ & 17.57 & 0.774 & 3.806 & 1.13 & 4.301 \\
\hline $3 \mathrm{H}-4,119.5$ & 17.59 & 0.775 & 3.806 & 1.13 & 4.301 \\
\hline $3 \mathrm{H}-4,125.5$ & 17.65 & 0.776 & 3.806 & 1.03 & 3.920 \\
\hline $3 \mathrm{H}-4,131.5$ & 17.72 & 0.778 & 3.806 & 0.91 & 3.463 \\
\hline $3 \mathrm{H}-4,134.6$ & 17.75 & 0.779 & 3.806 & 0.93 & 3.540 \\
\hline $3 \mathrm{H}-4,140.5$ & 17.81 & 0.781 & 1.429 & 0.88 & 1.258 \\
\hline $3 \mathrm{H}-4,146.5$ & 17.86 & 0.784 & 1.429 & 0.99 & 1.415 \\
\hline $3 \mathrm{H}-5,5.5$ & 17.95 & 0.790 & 1.429 & 0.94 & 1.343 \\
\hline $3 \mathrm{H}-5,11.5$ & 18.01 & 0.795 & 1.429 & 0.85 & 1.215 \\
\hline $3 \mathrm{H}-5,14.5$ & 18.05 & 0.798 & 1.429 & 0.98 & 1.400 \\
\hline $3 \mathrm{H}-5,20.5$ & 18.10 & 0.801 & 1.429 & 0.98 & 1.400 \\
\hline $3 \mathrm{H}-5,26.5$ & 18.16 & 0.805 & 1.429 & 0.94 & 1.343 \\
\hline $3 \mathrm{H}-5,29.5$ & 18.19 & 0.807 & 1.429 & 0.98 & 1.400 \\
\hline $3 \mathrm{H}-5,35.5$ & 18.25 & 0.812 & 1.429 & 0.84 & 1.200 \\
\hline $3 \mathrm{H}-5,41.5$ & 18.32 & 0.816 & 1.429 & 0.94 & 1.343 \\
\hline $3 \mathrm{H}-5,44.6$ & 18.35 & 0.818 & 1.429 & 0.86 & 1.229 \\
\hline $3 \mathrm{H}-5,50.5$ & 18.40 & 0.822 & 1.429 & 0.90 & 1.286 \\
\hline $3 \mathrm{H}-5,56.5$ & 18.47 & 0.827 & 1.429 & 0.93 & 1.329 \\
\hline $3 \mathrm{H}-5,59.5$ & 18.49 & 0.828 & 1.429 & 1.01 & 1.443 \\
\hline $3 \mathrm{H}-5,65.5$ & 18.56 & 0.833 & 1.429 & 0.91 & 1.300 \\
\hline $3 \mathrm{H}-5,71.5$ & 18.61 & 0.837 & 1.429 & 1.01 & 1.443 \\
\hline $3 \mathrm{H}-5,74.5$ & 18.65 & 0.840 & 1.429 & 0.96 & 1.372 \\
\hline $3 \mathrm{H}-5,80.5$ & 18.70 & 0.843 & 1.429 & 0.93 & 1.329 \\
\hline $3 \mathrm{H}-5,86.6$ & 18.77 & 0.848 & 1.429 & 0.92 & 1.315 \\
\hline $3 \mathrm{H}-5,89.5$ & 18.80 & 0.850 & 1.429 & 0.93 & 1.329 \\
\hline $3 \mathrm{H}-5,95.5$ & 18.85 & 0.854 & 1.429 & 0.91 & 1.300 \\
\hline $3 \mathrm{H}-5,101.5$ & 18.91 & 0.858 & 1.429 & 0.90 & 1.286 \\
\hline $3 \mathrm{H}-5,104.5$ & 18.94 & 0.860 & 1.429 & 0.90 & 1.286 \\
\hline $3 \mathrm{H}-5,110.7$ & 19.01 & 0.865 & 1.429 & 0.93 & 1.329 \\
\hline $3 \mathrm{H}-5,116.6$ & 19.07 & 0.869 & 1.429 & 0.89 & 1.272 \\
\hline $3 \mathrm{H}-5,119.5$ & 19.09 & 0.870 & 1.429 & 0.94 & 1.343 \\
\hline
\end{tabular}


APPENDIX C (continued).

\begin{tabular}{|c|c|c|c|c|c|c|c|}
\hline Core, section. & Depth & Age & & & MAR & CAR & NCAR \\
\hline interval $(\mathrm{cm})$ & (mbsf) & (Ma) & $(\mathrm{cm} / \mathrm{k} . \mathrm{y})$. & $\left(\mathrm{g} / \mathrm{cm}^{3}\right)$ & & & $\mathrm{n}^{2} \times \mathrm{k} . \mathrm{y}$ \\
\hline $3 \mathrm{H}-5,125.5$ & 19.15 & 0.874 & 1.429 & 0.83 & 1.186 & 0.673 & 0.513 \\
\hline $3 \mathrm{H}-5,128.6$ & 19.19 & 0.877 & 1.429 & 0.82 & 1.172 & 0.686 & 0.486 \\
\hline $3 \mathrm{H}-5,134.5$ & 19.24 & 0.881 & 1.429 & 0.83 & 1.186 & 0.713 & 0.473 \\
\hline $3 \mathrm{H}-5,149.6$ & 19.40 & 0.892 & 1.429 & 0.93 & 1.329 & 0.807 & 0.522 \\
\hline $3 \mathrm{H}-6,5.5$ & 19.45 & 0.896 & 1.429 & 0.84 & 1.200 & 0.753 & 0.447 \\
\hline $3 \mathrm{H}-6,11.5$ & 19.51 & 0.900 & 1.429 & 0.96 & 1.372 & 0.902 & 0.470 \\
\hline $3 \mathrm{H}-6,14.5$ & 19.55 & 0.902 & 1.429 & 0.98 & 1.400 & 0.853 & 0.547 \\
\hline $3 \mathrm{H}-6,20.6$ & 19.61 & 0.907 & 1.429 & 0.84 & 1.200 & 0.678 & 0.522 \\
\hline $3 \mathrm{H}-6,26.5$ & 19.66 & 0.910 & 1.429 & 0.94 & 1.343 & 0.804 & 0.539 \\
\hline $3 \mathrm{H}-6,29.5$ & 19.69 & 0.912 & 1.429 & 0.83 & 1.186 & 0.873 & 0.313 \\
\hline $3 \mathrm{H}-6,35.5$ & 19.75 & 0.916 & 1.429 & 0.98 & 1.400 & 1.056 & 0.344 \\
\hline $3 \mathrm{H}-6,41.7$ & 19.82 & 0.921 & 1.429 & 1.03 & 1.472 & 1.057 & 0.415 \\
\hline $3 \mathrm{H}-6,44.5$ & 19.84 & 0.923 & 1.429 & 0.91 & 1.300 & 0.928 & 0.372 \\
\hline $3 \mathrm{H}-6,50.5$ & 19.90 & 0.927 & 1.429 & 0.98 & 1.400 & 1.003 & 0.397 \\
\hline $3 \mathrm{H}-6,56.5$ & 19.97 & 0.932 & 1.429 & 0.96 & 1.372 & 0.879 & 0.492 \\
\hline $3 \mathrm{H}-6,59.5$ & 19.99 & 0.933 & 1.429 & 0.93 & 1.329 & 0.793 & 0.536 \\
\hline $3 \mathrm{H}-6,65.5$ & 20.06 & 0.938 & 1.429 & 0.87 & 1.243 & 0.748 & 0.496 \\
\hline $3 \mathrm{H}-6,71.5$ & 20.11 & 0.942 & 1.429 & 0.84 & 1.200 & 0.730 & 0.470 \\
\hline $3 \mathrm{H}-6,74.5$ & 20.15 & 0.945 & 1.429 & 0.86 & 1.229 & 0.766 & 0.463 \\
\hline $3 \mathrm{H}-6,80.5$ & 20.20 & 0.948 & 1.429 & 0.93 & 1.329 & 0.963 & 0.366 \\
\hline $3 \mathrm{H}-6,86.5$ & 20.26 & 0.952 & 1.429 & 0.99 & 1.415 & 1.164 & 0.250 \\
\hline $3 \mathrm{H}-6,89.5$ & 20.30 & 0.955 & 1.429 & 1.04 & 1.486 & 1.242 & 0.245 \\
\hline $3 \mathrm{H}-6,95.5$ & 20.35 & 0.959 & 1.429 & 1.09 & 1.558 & 1.336 & 0.221 \\
\hline $3 \mathrm{H}-6,101.5$ & 20.41 & 0.963 & 1.429 & 0.96 & 1.372 & 1.162 & 0.210 \\
\hline $3 \mathrm{H}-6,104.6$ & 20.45 & 0.965 & 1.429 & 1.09 & 1.558 & 1.229 & 0.328 \\
\hline $3 \mathrm{H}-6,110.5$ & 20.50 & 0.969 & 1.429 & 0.93 & 1.329 & 0.900 & 0.429 \\
\hline $3 \mathrm{H}-6,116.6$ & 20.57 & 0.974 & 1.429 & 0.94 & 1.343 & 0.755 & 0.589 \\
\hline $3 \mathrm{H}-6,119.5$ & 20.59 & 0.975 & 1.429 & 0.84 & 1.200 & 0.766 & 0.434 \\
\hline $3 \mathrm{H}-6,125.5$ & 20.65 & 0.979 & 1.429 & 0.96 & 1.372 & 0.939 & 0.433 \\
\hline $3 \mathrm{H}-6,131.5$ & 20.72 & 0.984 & 1.429 & 1.07 & 1.529 & 0.958 & 0.571 \\
\hline $3 \mathrm{H}-6,134.7$ & 20.75 & 0.987 & 1.429 & 1.03 & 1.472 & 1.152 & 0.320 \\
\hline $3 \mathrm{H}-6,140.7$ & 20.81 & 0.993 & 0.348 & 0.96 & 0.334 & 0.279 & 0.055 \\
\hline $3 \mathrm{H}-6,146.5$ & 20.86 & 1.007 & 0.348 & 0.90 & 0.313 & 0.239 & 0.075 \\
\hline $3 \mathrm{H}-7,5.5$ & 20.95 & 1.033 & 0.348 & 0.93 & 0.324 & 0.212 & 0.112 \\
\hline $3 \mathrm{H}-7,11.5$ & 21.01 & 1.050 & 0.348 & 1.05 & 0.365 & 0.265 & 0.100 \\
\hline $3 \mathrm{H}-7,20.5$ & 21.10 & 1.076 & 0.348 & 0.98 & 0.341 & 0.271 & 0.070 \\
\hline $3 \mathrm{H}-7,26.5$ & 21.16 & 1.093 & 0.348 & 0.98 & 0.341 & 0.253 & 0.088 \\
\hline $3 \mathrm{H}-7,29.5$ & 21.19 & 1.102 & 0.348 & 0.92 & 0.320 & 0.248 & 0.072 \\
\hline $3 \mathrm{H}-7,35.5$ & 21.25 & 1.119 & 0.348 & 0.90 & 0.313 & 0.224 & 0.089 \\
\hline $3 \mathrm{H}-7,41.5$ & 21.32 & 1.139 & 0.348 & 0.91 & 0.317 & 0.195 & 0.122 \\
\hline $3 \mathrm{H}-7,44.6$ & 21.35 & 1.148 & 0.348 & 0.91 & 0.317 & 0.215 & 0.101 \\
\hline $3 \mathrm{H}-7,50.5$ & 21.40 & 1.162 & 0.348 & 0.88 & 0.306 & 0.201 & 0.105 \\
\hline $4 \mathrm{H}-1,5.5$ & 21.45 & 1.177 & 0.348 & 0.90 & 0.313 & 0.166 & 0.147 \\
\hline $4 \mathrm{H}-1,11.5$ & 21.51 & 1.194 & 0.348 & 0.85 & 0.296 & 0.161 & 0.135 \\
\hline $4 \mathrm{H}-1,14.5$ & 21.55 & 1.206 & 0.348 & 0.90 & 0.313 & 0.191 & 0.122 \\
\hline $4 \mathrm{H}-1,20.5$ & 21.60 & 1.220 & 0.348 & 0.87 & 0.303 & 0.163 & 0.140 \\
\hline $4 \mathrm{H}-1,26.5$ & 21.66 & 1.237 & 0.348 & 0.91 & 0.317 & 0.189 & 0.128 \\
\hline $4 \mathrm{H}-1,29.5$ & 21.69 & 1.241 & 1.461 & 0.85 & 1.242 & 0.661 & 0.580 \\
\hline $4 \mathrm{H}-1,35.6$ & 21.76 & 1.246 & 1.461 & 0.85 & 1.242 & 0.892 & 0.350 \\
\hline $4 \mathrm{H}-1,41.7$ & 21.82 & 1.250 & 1.461 & 0.99 & 1.446 & 0.906 & 0.540 \\
\hline $4 \mathrm{H}-1,44.7$ & 21.85 & 1.252 & 1.461 & 0.94 & 1.373 & 1.076 & 0.297 \\
\hline $4 \mathrm{H}-1,50.6$ & 21.91 & 1.256 & 1.461 & 0.90 & 1.315 & 0.985 & 0.330 \\
\hline $4 \mathrm{H}-1,56.5$ & 21.97 & 1.260 & 1.461 & 0.99 & 1.446 & 1.053 & 0.394 \\
\hline $4 \mathrm{H}-1,59.5$ & 21.99 & 1.262 & 1.461 & 0.96 & 1.403 & 0.965 & 0.438 \\
\hline $4 \mathrm{H}-1,65.5$ & 22.06 & 1.267 & 1.461 & 0.99 & 1.446 & 0.899 & 0.547 \\
\hline $4 \mathrm{H}-1,71.7$ & 22.12 & 1.271 & 1.461 & 0.87 & 1.271 & 0.707 & 0.564 \\
\hline $4 \mathrm{H}-1,74.6$ & 22.15 & 1.273 & 1.461 & 0.88 & 1.286 & 0.744 & 0.542 \\
\hline $4 \mathrm{H}-1,80.6$ & 22.21 & 1.277 & 1.461 & 0.99 & 1.446 & 1.208 & 0.238 \\
\hline $4 \mathrm{H}-1,86.6$ & 22.27 & 1.281 & 1.461 & 0.99 & 1.446 & 1.223 & 0.223 \\
\hline $4 \mathrm{H}-1,89.5$ & 22.30 & 1.283 & 1.461 & 1.05 & 1.534 & 1.322 & 0.212 \\
\hline $4 \mathrm{H}-1,95.5$ & 22.35 & 1.286 & 1.461 & 0.99 & 1.446 & 1.223 & 0.223 \\
\hline $4 \mathrm{H}-1,101.5$ & 22.41 & 1.291 & 1.461 & 0.91 & 1.330 & 1.113 & 0.217 \\
\hline $4 \mathrm{H}-1,104.6$ & 22.45 & 1.293 & 1.461 & 0.98 & 1.432 & 1.179 & 0.253 \\
\hline $4 \mathrm{H}-1,110.6$ & 22.51 & 1.298 & 1.461 & 0.94 & 1.373 & 1.101 & 0.273 \\
\hline $4 \mathrm{H}-1,116.5$ & 22.57 & 1.302 & 1.461 & 0.84 & 1.227 & 0.969 & 0.258 \\
\hline $4 \mathrm{H}-1,119.5$ & 22.59 & 1.303 & 1.461 & 0.91 & 1.330 & 1.023 & 0.307 \\
\hline $4 \mathrm{H}-1,125.5$ & 22.65 & 1.307 & 1.461 & 1.09 & 1.592 & 1.220 & 0.372 \\
\hline $4 \mathrm{H}-1,131.5$ & 22.72 & 1.312 & 1.461 & 1.03 & 1.505 & 1.137 & 0.368 \\
\hline $4 \mathrm{H}-1,134.5$ & 22.74 & 1.313 & 1.461 & 0.98 & 1.432 & 1.074 & 0.357 \\
\hline $4 \mathrm{H}-1,140.5$ & 22.81 & 1.318 & 1.461 & 0.98 & 1.432 & 0.998 & 0.433 \\
\hline $4 \mathrm{H}-1,146.5$ & 22.86 & 1.321 & 1.461 & 0.91 & 1.330 & 0.872 & 0.458 \\
\hline $4 \mathrm{H}-1,149.5$ & 22.90 & 1.324 & 1.461 & 0.94 & 1.373 & 0.841 & 0.532 \\
\hline $4 \mathrm{H}-2,5.6$ & 22.96 & 1.328 & 1.461 & 1.07 & 1.563 & 1.238 & 0.325 \\
\hline $4 \mathrm{H}-2,11.5$ & 23.01 & 1.332 & 1.461 & 1.01 & 1.476 & 1.269 & 0.206 \\
\hline $4 \mathrm{H}-2,14.5$ & 23.05 & 1.334 & 1.461 & 1.07 & 1.563 & 1.187 & 0.377 \\
\hline $4 \mathrm{H}-2,20.5$ & 23.10 & 1.338 & 1.461 & 1.03 & 1.505 & 0.946 & 0.559 \\
\hline $4 \mathrm{H}-2,26.6$ & 23.17 & 1.343 & 1.461 & 1.05 & 1.534 & 0.612 & 0.922 \\
\hline $4 \mathrm{H}-2,29.5$ & 23.19 & 1.344 & 1.461 & 1.09 & 1.592 & 1.417 & 0.176 \\
\hline $4 \mathrm{H}-2,35.5$ & 23.25 & 1.348 & 1.461 & 1.01 & 1.476 & 0.810 & 0.665 \\
\hline $4 \mathrm{H}-2,41.6$ & 23.32 & 1.353 & 1.461 & 0.94 & 1.373 & 1.077 & 0.296 \\
\hline $4 \mathrm{H}-2,44.5$ & 23.34 & 1.354 & 1.461 & 1.01 & 1.476 & 1.174 & 0.301 \\
\hline $4 \mathrm{H}-2,50.5$ & 23.40 & 1.358 & 1.461 & 0.96 & 1.403 & 1.131 & 0.272 \\
\hline $4 \mathrm{H}-2,56.6$ & 23.47 & 1.363 & 1.461 & 0.96 & 1.403 & 1.083 & 0.320 \\
\hline $4 \mathrm{H}-2,59.5$ & 23.49 & 1.365 & 1.461 & 0.99 & 1.446 & 1.147 & 0.300 \\
\hline $4 \mathrm{H}-2,65.5$ & 23.56 & 1.369 & 1.461 & 0.94 & 1.373 & 1.021 & 0.353 \\
\hline $4 \mathrm{H}-2,71.7$ & 23.62 & 1.373 & 1.461 & 0.93 & 1.359 & 0.951 & 0.408 \\
\hline $4 \mathrm{H}-2,74.7$ & 23.65 & 1.375 & 1.461 & 0.96 & 1.403 & 1.060 & 0.343 \\
\hline $4 \mathrm{H}-2,80.5$ & 23.70 & 1.379 & 1.461 & 0.98 & 1.432 & 0.935 & 0.497 \\
\hline $4 \mathrm{H}-2,86.5$ & 23.76 & 1.383 & 1.461 & 0.94 & 1.373 & 0.741 & 0.632 \\
\hline
\end{tabular}


APPENDIX C (continued).

\begin{tabular}{|c|c|c|c|c|c|c|c|}
\hline ction. & Depth & & & & MAR & CAR & NCAR \\
\hline interval $(\mathrm{cm})$ & (mbsf) & (Ma) & (cm/k.y.) & $\left(\mathrm{g} / \mathrm{cm}^{3}\right)$ & & & $\mathrm{m}^{2} \times \mathrm{k}$ \\
\hline $4 \mathrm{H}-2,89.5$ & 23.80 & 1.386 & 1.461 & 0.98 & 1.432 & 1.015 & 0.417 \\
\hline $4 \mathrm{H}-2,95.6$ & 23.86 & 1.390 & 1.461 & 0.95 & 1.388 & 1.153 & 0.235 \\
\hline $4 \mathrm{H}-2,101.5$ & 23.91 & 1.393 & 1.461 & 1.03 & 1.505 & 1.283 & 0.222 \\
\hline $4 \mathrm{H}-2,104.5$ & 23.94 & 1.395 & 1.461 & 0.99 & 1.446 & 1.232 & 0.214 \\
\hline $4 \mathrm{H}-2,110.6$ & 24.01 & 1.400 & 1.461 & 1.07 & 1.563 & 1.325 & 0.238 \\
\hline $4 \mathrm{H}-2,116.5$ & 24.07 & 1.404 & 1.461 & 1.11 & 1.622 & 1.349 & 0.273 \\
\hline $4 \mathrm{H}-2,119.5$ & 24.09 & 1.406 & 1.461 & 1.13 & 1.651 & 1.375 & 0.276 \\
\hline $4 \mathrm{H}-2,125.5$ & 24.15 & 1.410 & 1.461 & 0.90 & 1.315 & 1.113 & 0.202 \\
\hline $4 \mathrm{H}-2,131.5$ & 24.22 & 1.415 & 1.461 & 0.99 & 1.446 & 1.210 & 0.236 \\
\hline $4 \mathrm{H}-2,134.5$ & 24.24 & 1.416 & 1.461 & 1.01 & 1.476 & 1.235 & 0.240 \\
\hline $4 \mathrm{H}-2,140.5$ & 24.31 & 1.421 & 1.461 & 1.13 & 1.651 & 1.375 & 0.276 \\
\hline $4 \mathrm{H}-2,146.6$ & 24.37 & 1.425 & 1.461 & 1.01 & 1.476 & 1.234 & 0.242 \\
\hline $4 \mathrm{H}-2,149.5$ & 24.40 & 1.427 & 1.461 & 1.03 & 1.505 & 1.156 & 0.349 \\
\hline $4 \mathrm{H}-3,5.6$ & 24.46 & 1.431 & 1.461 & 0.91 & 1.330 & 0.956 & 0.373 \\
\hline $4 \mathrm{H}-3,11.5$ & 24.51 & 1.434 & 1.461 & 0.94 & 1.373 & 0.815 & 0.559 \\
\hline $4 \mathrm{H}-3,14.6$ & 24.55 & 1.437 & 1.461 & 0.91 & 1.330 & 0.824 & 0.505 \\
\hline $4 \mathrm{H}-3,20.5$ & 24.60 & 1.441 & 1.461 & 0.98 & 1.432 & 0.907 & 0.525 \\
\hline $4 \mathrm{H}-3,26.5$ & 24.66 & 1.445 & 1.461 & 0.90 & 1.315 & 0.737 & 0.578 \\
\hline $4 \mathrm{H}-3,29.5$ & 24.69 & 1.447 & 1.461 & 0.90 & 1.315 & 0.766 & 0.549 \\
\hline $4 \mathrm{H}-3,35.7$ & 24.76 & 1.452 & 1.461 & 0.77 & 1.125 & 0.621 & 0.504 \\
\hline $4 \mathrm{H}-3,41.6$ & 24.82 & 1.456 & 1.461 & 0.96 & 1.403 & 0.811 & 0.592 \\
\hline $4 \mathrm{H}-3,44.5$ & 24.84 & 1.457 & 2.457 & 0.90 & 2.211 & 1.575 & 0.636 \\
\hline $4 \mathrm{H}-3,50.5$ & 24.90 & 1.459 & 2.457 & 0.94 & 2.310 & 1.811 & 0.499 \\
\hline $4 \mathrm{H}-3,56.5$ & 24.97 & 1.462 & 2.457 & 1.01 & 2.482 & 1.976 & 0.506 \\
\hline $4 \mathrm{H}-3,59.5$ & 24.99 & 1.463 & 2.457 & 1.03 & 2.531 & 2.070 & 0.461 \\
\hline $4 \mathrm{H}-3,65.5$ & 25.06 & 1.466 & 2.457 & 0.98 & 2.408 & 1.951 & 0.457 \\
\hline $4 \mathrm{H}-3,71.5$ & 25.11 & 1.468 & 2.457 & 0.94 & 2.310 & 1.815 & 0.495 \\
\hline $4 \mathrm{H}-3,74.6$ & 25.15 & 1.470 & 2.457 & 0.94 & 2.310 & 1.789 & 0.520 \\
\hline $4 \mathrm{H}-3,80.6$ & 25.21 & 1.472 & 2.457 & 0.99 & 2.432 & 2.071 & 0.361 \\
\hline $4 \mathrm{H}-3,86.5$ & 25.26 & 1.474 & 2.457 & 0.94 & 2.310 & 1.937 & 0.373 \\
\hline $4 \mathrm{H}-3,89.6$ & 25.30 & 1.476 & 2.457 & 0.87 & 2.138 & 1.778 & 0.360 \\
\hline $4 \mathrm{H}-3,95.6$ & 25.36 & 1.478 & 2.457 & 0.90 & 2.211 & 1.850 & 0.362 \\
\hline $4 \mathrm{H}-3,101.5$ & 25.41 & 1.480 & 2.457 & 0.88 & 2.162 & 1.724 & 0.438 \\
\hline $4 \mathrm{H}-3,104.5$ & 25.44 & 1.481 & 2.457 & 0.91 & 2.236 & 1.622 & 0.614 \\
\hline $4 \mathrm{H}-3,110.5$ & 25.50 & 1.484 & 2.457 & 0.87 & 2.138 & 1.469 & 0.669 \\
\hline $4 \mathrm{H}-3,116.6$ & 25.57 & 1.487 & 2.457 & 0.88 & 2.162 & 1.288 & 0.874 \\
\hline $4 \mathrm{H}-3,119.5$ & 25.59 & 1.487 & 2.457 & 0.98 & 2.408 & 1.504 & 0.904 \\
\hline $4 \mathrm{H}-3,125.5$ & 25.65 & 1.490 & 2.457 & 0.98 & 2.408 & 1.467 & 0.941 \\
\hline $4 \mathrm{H}-3,134.5$ & 25.74 & 1.494 & 2.457 & 1.25 & 3.071 & 1.731 & 1.340 \\
\hline $4 \mathrm{H}-3,140.7$ & 25.81 & 1.497 & 2.457 & 0.91 & 2.236 & 1.290 & 0.946 \\
\hline $4 \mathrm{H}-3,146.5$ & 25.86 & 1.498 & 2.457 & 0.95 & 2.334 & 1.458 & 0.876 \\
\hline $4 \mathrm{H}-3,149.7$ & 25.90 & 1.500 & 2.457 & 1.01 & 2.482 & 1.857 & 0.624 \\
\hline $4 \mathrm{H}-4,5.5$ & 25.95 & 1.502 & 2.457 & 0.94 & 2.310 & 1.842 & 0.468 \\
\hline $4 \mathrm{H}-4,11.5$ & 26.01 & 1.505 & 2.457 & 0.98 & 2.408 & 1.964 & 0.444 \\
\hline $4 \mathrm{H}-4,14.5$ & 26.05 & 1.506 & 2.457 & 0.99 & 2.432 & 2.048 & 0.385 \\
\hline $4 \mathrm{H}-4,20.5$ & 26.10 & 1.508 & 2.457 & 0.94 & 2.310 & 1.915 & 0.394 \\
\hline $4 \mathrm{H}-4,26.5$ & 26.16 & 1.511 & 2.457 & 0.96 & 2.359 & 1.930 & 0.429 \\
\hline $4 \mathrm{H}-4,29.6$ & 26.20 & 1.512 & 2.457 & 0.87 & 2.138 & 1.722 & 0.415 \\
\hline $4 \mathrm{H}-4,35.5$ & 26.25 & 1.514 & 2.457 & 0.94 & 2.310 & 1.858 & 0.452 \\
\hline $4 \mathrm{H}-4,41.5$ & 26.32 & 1.517 & 2.457 & 0.88 & 2.162 & 1.759 & 0.403 \\
\hline $4 \mathrm{H}-4,44.5$ & 26.34 & 1.518 & 2.457 & 0.96 & 2.359 & 1.846 & 0.513 \\
\hline $4 \mathrm{H}-4,50.5$ & 26.40 & 1.520 & 2.457 & 0.88 & 2.162 & 1.666 & 0.496 \\
\hline $4 \mathrm{H}-4,56.6$ & 26.47 & 1.523 & 2.457 & 0.90 & 2.211 & 1.613 & 0.598 \\
\hline $4 \mathrm{H}-4,59.6$ & 26.50 & 1.525 & 2.457 & 0.88 & 2.162 & 1.418 & 0.744 \\
\hline $4 \mathrm{H}-4,65.5$ & 26.56 & 1.527 & 2.457 & 0.88 & 2.162 & 1.380 & 0.782 \\
\hline $4 \mathrm{H}-4,71.6$ & 26.62 & 1.529 & 2.457 & 0.79 & 1.941 & 1.189 & 0.752 \\
\hline $4 \mathrm{H}-4,74.5$ & 26.65 & 1.531 & 2.457 & 0.85 & 2.088 & 1.223 & 0.866 \\
\hline $4 \mathrm{H}-4,80.5$ & 26.70 & 1.533 & 2.457 & 0.94 & 2.310 & 1.282 & 1.027 \\
\hline $4 \mathrm{H}-4,86.5$ & 26.76 & 1.535 & 2.457 & 0.93 & 2.285 & 1.496 & 0.789 \\
\hline $4 \mathrm{H}-4,89.5$ & 26.80 & 1.537 & 2.457 & 0.98 & 2.408 & 1.464 & 0.944 \\
\hline $4 \mathrm{H}-4,95.7$ & 26.86 & 1.539 & 2.457 & 0.88 & 2.162 & 1.403 & 0.759 \\
\hline $4 \mathrm{H}-4,101.6$ & 26.92 & 1.542 & 2.457 & 0.87 & 2.138 & 1.208 & 0.930 \\
\hline $4 \mathrm{H}-4,104.5$ & 26.94 & 1.543 & 2.457 & 0.87 & 2.138 & 1.272 & 0.866 \\
\hline $4 \mathrm{H}-4,110.5$ & 27.00 & 1.545 & 2.457 & 0.91 & 2.236 & 1.213 & 1.023 \\
\hline $4 \mathrm{H}-4,116.6$ & 27.07 & 1.548 & 2.457 & 0.99 & 2.432 & 1.876 & 0.557 \\
\hline $4 \mathrm{H}-4,119.5$ & 27.09 & 1.549 & 2.457 & 0.99 & 2.432 & 1.867 & 0.565 \\
\hline $4 \mathrm{H}-4,125.7$ & 27.16 & 1.551 & 2.457 & 0.90 & 2.211 & 1.769 & 0.442 \\
\hline $4 \mathrm{H}-4,131.6$ & 27.22 & 1.554 & 2.457 & 0.99 & 2.432 & 1.819 & 0.613 \\
\hline $4 \mathrm{H}-4,134.5$ & 27.24 & 1.555 & 2.457 & 0.96 & 2.359 & 1.510 & 0.848 \\
\hline $4 \mathrm{H}-4,140.6$ & 27.31 & 1.558 & 2.457 & 0.91 & 2.236 & 1.677 & 0.559 \\
\hline $4 \mathrm{H}-4,146.5$ & 27.36 & 1.560 & 2.457 & 0.91 & 2.236 & 1.756 & 0.480 \\
\hline $4 \mathrm{H}-4,149.5$ & 27.40 & 1.561 & 2.457 & 0.93 & 2.285 & 1.756 & 0.529 \\
\hline $4 \mathrm{H}-5,5.7$ & 27.46 & 1.564 & 2.457 & 0.87 & 2.138 & 1.621 & 0.516 \\
\hline $4 \mathrm{H}-5,11.5$ & 27.51 & 1.566 & 2.457 & 0.94 & 2.310 & 1.755 & 0.554 \\
\hline $4 \mathrm{H}-5,14.6$ & 27.55 & 1.567 & 2.457 & 0.94 & 2.310 & 1.802 & 0.508 \\
\hline $4 \mathrm{H}-5,20.6$ & 27.61 & 1.570 & 2.457 & 1.01 & 2.482 & 1.962 & 0.519 \\
\hline $4 \mathrm{H}-5,26.5$ & 27.66 & 1.572 & 2.457 & 1.03 & 2.531 & 1.903 & 0.628 \\
\hline $4 \mathrm{H}-5,29.5$ & 27.69 & 1.573 & 2.457 & 1.01 & 2.482 & 1.707 & 0.774 \\
\hline $4 \mathrm{H}-5,35.5$ & 27.75 & 1.575 & 2.457 & 0.88 & 2.162 & 1.383 & 0.779 \\
\hline $4 \mathrm{H}-5,41.5$ & 27.82 & 1.578 & 2.457 & 0.88 & 2.162 & 1.115 & 1.048 \\
\hline $4 \mathrm{H}-5,44.5$ & 27.84 & 1.579 & 2.457 & 0.87 & 2.138 & 1.151 & 0.987 \\
\hline $4 \mathrm{H}-5,50.6$ & 27.91 & 1.582 & 2.457 & 0.98 & 2.408 & 1.789 & 0.619 \\
\hline $4 \mathrm{H}-5,56.6$ & 27.97 & 1.584 & 2.457 & 0.93 & 2.285 & 1.611 & 0.674 \\
\hline $4 \mathrm{H}-5,59.5$ & 27.99 & 1.585 & 2.457 & 0.91 & 2.236 & 1.321 & 0.915 \\
\hline $4 \mathrm{H}-5,65.5$ & 28.06 & 1.588 & 2.457 & 0.96 & 2.359 & 1.693 & 0.666 \\
\hline $4 \mathrm{H}-5,71.6$ & 28.12 & 1.590 & 2.457 & 0.82 & 2.015 & 1.301 & 0.714 \\
\hline $4 \mathrm{H}-5,74.6$ & 28.15 & 1.592 & 2.457 & 0.95 & 2.334 & 1.808 & 0.527 \\
\hline $4 \mathrm{H}-5,80.7$ & 28.21 & 1.594 & 2.457 & 0.88 & 2.162 & 1.676 & 0.486 \\
\hline $4 \mathrm{H}-5,86.6$ & 28.27 & 1.597 & 2.457 & 1.04 & 2.555 & 1.912 & 0.643 \\
\hline
\end{tabular}


F.R. RACK ET AL.

APPENDIX C (continued).

\begin{tabular}{|c|c|c|c|c|c|c|c|c|c|c|}
\hline Core, section, & Depth & Age & LSR & D & MAR & CAR & NCAR & OMAR & TMAR $^{1}$ & TMAR $^{2}$ \\
\hline interval $(\mathrm{cm})$ & (mbsf) & (Ma) & $(\mathrm{cm} / \mathrm{k} . \mathrm{y})$. & $\left(\mathrm{g} / \mathrm{cm}^{3}\right)$ & & & $\mathrm{n}^{2} \times \mathrm{k} \cdot \mathrm{y}$ & & & $\mathrm{mg}\left(\mathrm{cm}^{2} \times \mathrm{k} . \mathrm{y} .\right)^{-1}$ \\
\hline $4 \mathrm{H}-5,89.5$ & 28.30 & 1.629 & 0.063 & 0.85 & 0.054 & 0.038 & 0.016 & & & \\
\hline $4 \mathrm{H}-5,95.7$ & 28.36 & 1.723 & 0.063 & 0.99 & 0.062 & 0.043 & 0.019 & & & \\
\hline $4 \mathrm{H}-5,101.6$ & 28.42 & 1.818 & 0.063 & 1.02 & 0.064 & 0.042 & 0.022 & 0.011 & 0.011 & 11 \\
\hline $4 \mathrm{H}-5,104.6$ & 28.45 & 1.865 & 0.063 & 0.94 & 0.059 & 0.048 & 0.011 & & & \\
\hline $4 \mathrm{H}-5,110.5$ & 28.50 & 1.944 & 0.063 & 0.99 & 0.062 & 0.050 & 0.012 & 0.007 & 0.005 & 5 \\
\hline $4 \mathrm{H}-5,116.5$ & 28.57 & 1.964 & 1.468 & 0.94 & 1.380 & 1.066 & 0.314 & & & \\
\hline $4 \mathrm{H}-5,119.5$ & $\begin{array}{l}28.59 \\
28.65\end{array}$ & 1.965 & 1.468 & 0.90 & 1.321 & 0.896 & 0.425 & & & \\
\hline $\begin{array}{l}4 \mathrm{H}-5,125.5 \\
4 \mathrm{H}-5,131.5\end{array}$ & $\begin{array}{l}28.65 \\
28.72\end{array}$ & $\begin{array}{l}1.969 \\
1.974\end{array}$ & $\begin{array}{l}1.468 \\
1.468\end{array}$ & $\begin{array}{l}0.91 \\
0.90\end{array}$ & $\begin{array}{l}1.336 \\
1.321\end{array}$ & $\begin{array}{l}0.948 \\
0.825\end{array}$ & $\begin{array}{l}0.387 \\
0.496\end{array}$ & 0.176 & 0.212 & 212 \\
\hline $4 \mathrm{H}-5,134.5$ & 28.74 & 1.976 & 1.468 & 0.93 & 1.365 & 0.710 & 0.655 & 0.280 & 0.375 & 375 \\
\hline $4 \mathrm{H}-5,140.5$ & 28.81 & 1.980 & 1.468 & 1.01 & 1.483 & 1.067 & 0.416 & & 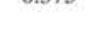 & \\
\hline $4 \mathrm{H}-5,146.5$ & 28.86 & 1.984 & 1.468 & 0.96 & 1.409 & 0.978 & 0.431 & & & \\
\hline $4 \mathrm{H}-5,149.5$ & 28.90 & 1.987 & 1.468 & 0.99 & 1.453 & 1.238 & 0.215 & 0.097 & 0.118 & 118 \\
\hline $4 \mathrm{H}-6.5 .5$ & 28.95 & 1.990 & 1.468 & 1.01 & 1.483 & 1.275 & 0.207 & & & \\
\hline $4 \mathrm{H}-6,11.5$ & 29.01 & 1.994 & 1.468 & 0.99 & 1.453 & 1.266 & 0.187 & & & \\
\hline $4 \mathrm{H}-6,14.5$ & 29.05 & 1.997 & 1.468 & 0.93 & 1.365 & 1.186 & 0.179 & & & \\
\hline $4 \mathrm{H}-6,20.5$ & 29.10 & 2.000 & 1.468 & 0.93 & 1.365 & 1.188 & 0.177 & & & \\
\hline $\begin{array}{l}4 \mathrm{H}-6,26.6 \\
4 \mathrm{H}-6,29.5\end{array}$ & $\begin{array}{l}29.17 \\
29.19\end{array}$ & $\begin{array}{l}2.005 \\
2.006\end{array}$ & $\begin{array}{l}1.468 \\
1.468\end{array}$ & $\begin{array}{l}0.92 \\
0.91\end{array}$ & $\begin{array}{l}1.351 \\
1.336\end{array}$ & $\begin{array}{l}1.178 \\
1.157\end{array}$ & $\begin{array}{l}0.172 \\
0.179\end{array}$ & 0.110 & 0.068 & 68 \\
\hline $4 \mathrm{H}-6,35.5$ & 29.25 & 2.010 & 1.468 & 0.93 & 1.365 & 1.119 & 0.246 & 0.10 & & \\
\hline $4 \mathrm{H}-6,41.5$ & 29.32 & 2.015 & 1.468 & 0.93 & 1.365 & 1.030 & 0.335 & & & \\
\hline $4 \mathrm{H}-6,44.5$ & 29.34 & 2.016 & 1.468 & 0.94 & 1.380 & 1.029 & 0.351 & 0.181 & 0.171 & 171 \\
\hline $4 \mathrm{H}-6,50.6$ & 29.41 & 2.021 & 1.468 & 0.96 & 1.409 & 1.018 & 0.391 & & & \\
\hline $4 \mathrm{H}-6,56.5$ & 29.47 & 2.025 & 1.468 & 0.96 & 1.409 & 1.097 & 0.312 & & & \\
\hline $4 \mathrm{H}-6,59.6$ & 29.50 & 2.027 & 1.468 & 1.07 & 1.571 & 1.267 & 0.303 & 0.139 & 0.164 & 164 \\
\hline $4 \mathrm{H}-6,65.6$ & 29.56 & 2.032 & 1.468 & 0.96 & 1.409 & 1.074 & 0.335 & & & \\
\hline $4 \mathrm{H}-6,71.5$ & 29.61 & 2.035 & 1.468 & 0.94 & 1.380 & 0.877 & 0.503 & 0.291 & 0.212 & 212 \\
\hline $4 \mathrm{H}-6,74.7$ & 29.65 & 2.038 & 1.468 & 1.11 & 1.629 & 1.318 & 0.311 & & & \\
\hline $4 \mathrm{H}-6,80.5$ & 29.70 & 2.041 & 1.468 & 1.01 & 1.483 & 1.220 & 0.262 & & & \\
\hline $4 \mathrm{H}-6,86.5$ & 29.76 & 2.045 & 1.468 & 1.11 & 1.629 & 1.391 & 0.239 & & & 74 \\
\hline $\begin{array}{l}4 \mathrm{H}-6,89.5 \\
4 \mathrm{H}-6.95 .5\end{array}$ & $\begin{array}{l}29.80 \\
29.85\end{array}$ & $\begin{array}{l}2.048 \\
2.051\end{array}$ & $\begin{array}{l}1.468 \\
1.468\end{array}$ & $\begin{array}{l}1.07 \\
1.09\end{array}$ & 1.571 & 1.373 & 0.197 & 0.124 & 0.074 & 74 \\
\hline $\begin{array}{l}4 \mathrm{H}-6,95.5 \\
4 \mathrm{H}-6,101.5\end{array}$ & 29.91 & $\begin{array}{l}2.051 \\
2.055\end{array}$ & $\begin{array}{l}1.468 \\
1.468\end{array}$ & $\begin{array}{l}1.09 \\
1.11\end{array}$ & $\begin{array}{l}1.600 \\
1.629\end{array}$ & $\begin{array}{l}1.384 \\
1.380\end{array}$ & $\begin{array}{l}0.216 \\
0.250\end{array}$ & & & \\
\hline $\begin{array}{l}4 \mathrm{H}-6,101.5 \\
4 \mathrm{H}-6,104.5\end{array}$ & 29.94 & 2.057 & 1.468 & 1.07 & 1.571 & 1.367 & 0.204 & & & \\
\hline $4 \mathrm{H}-6,110.5$ & 30.00 & 2.062 & 1.468 & 0.98 & 1.439 & 1.206 & 0.233 & & & \\
\hline $4 \mathrm{H}-6,116.7$ & 30.07 & 2.066 & 1.468 & 0.96 & 1.409 & 1.158 & 0.251 & & & \\
\hline $4 \mathrm{H}-6,119.5$ & 30.09 & 2.068 & 1.468 & 1.13 & 1.659 & 1.305 & 0.353 & & & \\
\hline $4 \mathrm{H}-6,125.5$ & 30.15 & 2.072 & 1.468 & 0.94 & 1.380 & 1.066 & 0.314 & 0.188 & 0.126 & 126 \\
\hline $4 \mathrm{H}-6,131.5$ & 30.22 & 2.076 & 1.468 & 0.87 & 1.277 & 0.979 & 0.298 & & & \\
\hline $4 \mathrm{H}-6,134.5$ & 30.24 & 2.078 & 1.468 & 1.01 & 1.483 & 1.205 & 0.278 & & & \\
\hline $4 H-6,140.6$ & 30.31 & 2.083 & 1.468 & 0.90 & 1.321 & 1.076 & 0.245 & & & \\
\hline $4 \mathrm{H}-6,146.5$ & 30.36 & 2.086 & 1.468 & 0.96 & 1.409 & 0.966 & 0.444 & & & \\
\hline $5 \mathrm{H}-1,5.5$ & 30.95 & 2.126 & 1.468 & 0.98 & 1.439 & 1.116 & 0.322 & & & \\
\hline $5 \mathrm{H}-1,11.5$ & 31.01 & 2.130 & 1.468 & 1.01 & 1.483 & 1.154 & 0.328 & & & \\
\hline $5 \mathrm{H}-1,17.6$ & 31.08 & 2.135 & 1.468 & 1.01 & 1.483 & 1.214 & 0.269 & & & \\
\hline $5 \mathrm{H}-1,20.5$ & 31.10 & 2.136 & 1.468 & 1.05 & 1.541 & 1.340 & 0.201 & 0.138 & 0.063 & 63 \\
\hline $5 \mathrm{H}-1,26.5$ & 31.16 & 2.141 & 1.468 & 1.01 & 1.483 & 1.285 & 0.197 & & & \\
\hline $5 \mathrm{H}-1,32.5$ & 31.23 & 2.145 & 1.468 & 1.11 & 1.629 & 1.277 & 0.353 & & & \\
\hline $5 \mathrm{H}-1,38.5$ & 31.28 & 2.149 & 1.468 & 1.09 & 1.600 & 1,358 & 0.242 & & & \\
\hline $5 \mathrm{H}-1,41.5$ & 31.32 & 2.151 & 1.511 & 0.96 & 1.451 & 1.238 & 0.213 & & & \\
\hline $5 \mathrm{H}-1,44.5$ & 31.34 & 2.153 & 1.511 & 0.94 & 1.420 & 1.140 & 0.281 & & & \\
\hline $5 \mathrm{H}-1,50.6$ & 31.41 & 2.157 & 1.511 & 1.03 & 1.556 & 1.272 & 0.284 & & & \\
\hline $5 \mathrm{H}-1,56.6$ & 31.47 & 2.161 & 1.511 & 1.02 & 1.541 & 1.225 & 0.316 & & & \\
\hline $5 \mathrm{H}-1,59.5$ & 31.49 & 2.163 & 1.511 & 1.03 & 1.556 & 1.162 & 0.394 & 0.191 & 0.204 & 204 \\
\hline $5 \mathrm{H}-1,65.5$ & 31.56 & 2.167 & 1.511 & 1.15 & 1.738 & 1.239 & 0.499 & & & \\
\hline $5 \mathrm{H}-1,71.5$ & 31.61 & 2.171 & 1.511 & 1.03 & 1.556 & 1.032 & 0.524 & & & \\
\hline $5 \mathrm{H}-1,74.5$ & 31.65 & 2.173 & 1.511 & 0.94 & 1.420 & 0.893 & 0.527 & & & \\
\hline $5 \mathrm{H}-1,80.5$ & 31.70 & 2.177 & 1.511 & 0.91 & 1.375 & 0.756 & 0.619 & 0.245 & 0.374 & 374 \\
\hline $5 \mathrm{H}-1,86.5$ & 31.76 & 2.180 & 1.511 & 0.87 & 1.315 & 0.762 & 0.553 & & & \\
\hline $5 \mathrm{H}-1,95.6$ & 31.86 & 2.187 & 1.511 & 1.09 & 1.647 & 1.315 & 0.332 & & & \\
\hline $5 \mathrm{H}-1.101 .5$ & 31.91 & 2.190 & 1.511 & 1.07 & 1.617 & 1.308 & 0.308 & & & \\
\hline $5 \mathrm{H}-1,104.5$ & 31.94 & 2.192 & 1.511 & 1.03 & 1.556 & 1.302 & 0.254 & & & \\
\hline $5 \mathrm{H}-1,110.5$ & 32.01 & 2.197 & 1.511 & 1.09 & 1.647 & 1.391 & 0.256 & 0.157 & 0.099 & 99 \\
\hline $5 \mathrm{H}-1,116.5$ & 32.06 & 2.200 & 1.511 & 0.98 & 1.481 & 1.244 & 0.237 & & & \\
\hline $5 \mathrm{H}-1,119.5$ & 32.10 & 2.203 & 1.511 & 1.04 & 1.571 & 1.238 & 0.334 & & & \\
\hline $5 \mathrm{H}-1,125.5$ & 32.15 & 2.206 & 1.511 & 1.03 & 1.556 & 1.177 & 0.379 & & & \\
\hline $5 \mathrm{H}-1,131.5$ & 32.22 & 2.211 & 1.511 & 0.96 & 1.451 & 1.031 & 0.419 & & & \\
\hline $5 \mathrm{H}-1,134.5$ & 32.24 & 2.212 & 1.511 & 1.01 & 1.526 & 1.106 & 0.420 & 0.195 & 0.225 & 225 \\
\hline $5 \mathrm{H}-1,140.5$ & 32.31 & 2.217 & 1.511 & 1.01 & 1.526 & 1.212 & 0.315 & & & \\
\hline $5 \mathrm{H}-1,146.5$ & 32.36 & 2.220 & 1.511 & 1.07 & 1.617 & 1.298 & 0.319 & & & \\
\hline $5 \mathrm{H}-1,149.5$ & 32.40 & 2.223 & 1.511 & 0.88 & 1.330 & 0.956 & 0.374 & & & \\
\hline $5 \mathrm{H}-2,5.5$ & 32.46 & 2.227 & 1.511 & 1.03 & 1.556 & 1.172 & 0.385 & & & \\
\hline $5 \mathrm{H}-2,11.5$ & 32.52 & 2.231 & 1.511 & 1.05 & 1.587 & 1.177 & 0.410 & & & \\
\hline $5 \mathrm{H}-2,14.5$ & 32.55 & 2.233 & 1.511 & 0.99 & 1.496 & 1.116 & 0.380 & 0.206 & 0.174 & 174 \\
\hline $5 \mathrm{H}-2,20.5$ & 32.61 & 2.237 & 1.511 & 1.03 & 1.556 & 1.079 & 0.477 & & & \\
\hline $5 \mathrm{H}-2,29.5$ & 32.69 & 2.242 & 1.511 & 0.99 & 1.496 & 0.940 & 0.556 & & & \\
\hline $5 \mathrm{H}-2,35.5$ & 32.76 & 2.247 & 1.511 & 1.03 & 1.556 & 1.095 & 0.461 & & & \\
\hline $5 \mathrm{H}-2,41.5$ & 32.82 & 2.251 & 1.511 & 0.98 & 1.481 & 1.021 & 0.460 & & & \\
\hline $5 \mathrm{H}-2,44.5$ & 32.85 & 2.253 & 1.511 & 0.88 & 1.330 & 0.819 & 0.511 & 0.178 & 0.333 & 333 \\
\hline $5 \mathrm{H}-2,50.5$ & 32.91 & 2.257 & 1.511 & 1.01 & 1.526 & 1.267 & 0.259 & & & \\
\hline $5 \mathrm{H}-2,56.5$ & 32.97 & 2.260 & 1.511 & 0.96 & 1.451 & 1.178 & 0.273 & & & \\
\hline $5 \mathrm{H}-2,59.5$ & 33.00 & 2.263 & 1.511 & 0.80 & 1.209 & 0.994 & 0.215 & & & \\
\hline $5 \mathrm{H}-2,65.5$ & 33.06 & 2.266 & 1.511 & 1.05 & 1.587 & 1.293 & 0.294 & & & \\
\hline $5 \mathrm{H}-2,71.5$ & 33.12 & 2.270 & 1.511 & 1.01 & 1.526 & 1.254 & 0.272 & & & \\
\hline $5 \mathrm{H}-2,74.5$ & 33.15 & 2.272 & 1.511 & 1.09 & 1.647 & 1.349 & 0.298 & 0.169 & 0.129 & 129 \\
\hline $5 \mathrm{H}-2,80.5$ & 33.21 & 2.276 & 1.511 & 0.96 & 1.451 & 1.172 & 0.279 & & & \\
\hline $5 \mathrm{H}-2,86.7$ & 33.27 & 2.280 & 1.511 & 1.03 & 1.556 & 1.244 & 0.312 & & & \\
\hline $5 \mathrm{H}-2,89.6$ & 33.30 & 2.282 & 1.511 & 0.94 & 1.420 & 1.061 & 0.360 & & & \\
\hline $5 \mathrm{H}-2,95.5$ & 33.36 & 2.286 & 1.511 & 0.94 & 1.420 & 0.998 & 0.422 & & & \\
\hline
\end{tabular}


APPENDIX C (continued).

\begin{tabular}{|c|c|c|c|c|c|c|c|c|}
\hline ction, & Depth & Age & LSR & DBD & MAR & CAR & NCAR & OMAR \\
\hline interval $(\mathrm{cm})$ & (mbsf) & (Ma) & $(\mathrm{cm} / \mathrm{k} . \mathrm{y})$, & $\left(\mathrm{g} / \mathrm{cm}^{3}\right)$ & & & $m^{2} \times k \cdot y$ & \\
\hline $5 \mathrm{H}-2,101.7$ & 33.42 & 2.290 & 1.511 & 0.91 & 1.375 & 0.858 & 0.517 & \\
\hline $5 \mathrm{H}-2,104.6$ & 33.45 & 2.292 & 1.511 & 0.91 & 1.375 & 0.822 & 0.553 & 0.258 \\
\hline $5 \mathrm{H}-2,110.6$ & 33.51 & 2.296 & 1.511 & 0.90 & 1.360 & 0.876 & 0.484 & \\
\hline $5 \mathrm{H}-2,119.5$ & 33.60 & 2.302 & 1.511 & 1.07 & 1.617 & 1.318 & 0.299 & 0.198 \\
\hline $5 \mathrm{H}-2,125.5$ & 33.66 & 2.306 & 1.511 & 1.13 & 1.707 & 1.431 & 0.276 & \\
\hline $5 \mathrm{H}-2,131.5$ & 33.72 & 2.310 & 1.511 & 1.07 & 1.617 & 1.311 & 0.306 & \\
\hline $5 \mathrm{H}-2,134.5$ & 33.75 & 2.312 & 1.511 & 1.09 & 1.647 & 1.274 & 0.373 & \\
\hline $5 \mathrm{H}-2,143.5$ & 33.84 & 2.318 & 1.511 & 0.93 & 1.405 & 1.101 & 0.305 & 0.172 \\
\hline $5 \mathrm{H}-2,149.6$ & 33.90 & 2.322 & 1.511 & 0.98 & 1.481 & 1.085 & 0.395 & \\
\hline $5 \mathrm{H}-3,2.5$ & 33.93 & 2.324 & 1.511 & 0.96 & 1.451 & 1.138 & 0.312 & \\
\hline $5 \mathrm{H}-3,5.5$ & 33.96 & 2.326 & 1.511 & 0.90 & 1.360 & $\begin{array}{l}1.057 \\
.057\end{array}$ & 0.303 & \\
\hline $5 \mathrm{H}-3,11.5$ & 34.02 & 2.330 & 1.511 & 0.88 & 1.330 & 0.957 & 0.373 & \\
\hline $\begin{array}{l}5 \mathrm{H}-3,14.5 \\
5 \mathrm{H}-3,20.5\end{array}$ & $\begin{array}{l}34.05 \\
34.11\end{array}$ & $\begin{array}{l}2.332 \\
2.336\end{array}$ & $\begin{array}{l}1.511 \\
1.511\end{array}$ & $\begin{array}{l}0.80 \\
0.91\end{array}$ & $\begin{array}{l}1.209 \\
1.375\end{array}$ & $\begin{array}{l}0.811 \\
1.134\end{array}$ & $\begin{array}{l}0.398 \\
0.241\end{array}$ & 0.206 \\
\hline $5 \mathrm{H}-3,26.5$ & 34.17 & 2.340 & 1.511 & 0.91 & 1.375 & 1.061 & 0.314 & \\
\hline $5 \mathrm{H}-3,29.6$ & 34.20 & 2.342 & 1.511 & 1.03 & 1.556 & 1.151 & 0.405 & 0.226 \\
\hline $5 \mathrm{H}-3,35.5$ & 34.26 & 2.346 & 1.511 & 0.91 & 1.375 & 0.863 & 0.512 & \\
\hline $5 \mathrm{H}-3,41.5$ & 34.32 & 2.350 & 1.511 & 0.90 & 1.360 & 0.776 & 0.584 & \\
\hline $5 \mathrm{H}-3,44.5$ & 34.35 & 2.352 & 1.511 & 1.07 & 1.617 & 0.592 & 1.025 & 0.597 \\
\hline $5 \mathrm{H}-3,50.5$ & 34.41 & 2.356 & 1.511 & 0.99 & 1.496 & 1.203 & 0.293 & \\
\hline $5 \mathrm{H}-3,56.5$ & 34.47 & 2.360 & 1.511 & 0.94 & 1.420 & 1.140 & 0.280 & \\
\hline $5 \mathrm{H}-3,59.6$ & 34.50 & 2.362 & 1.511 & 0.96 & 1.451 & 1.135 & 0.316 & \\
\hline $5 \mathrm{H}-3,65.5$ & 34.56 & 2.366 & 1.511 & 1.03 & 1.556 & 1.290 & 0.266 & \\
\hline $5 \mathrm{H}-3,71.5$ & 34.62 & 2.370 & 1.511 & 1.01 & 1.526 & 1.227 & 0.299 & \\
\hline $5 \mathrm{H}-3,74.6$ & 34.65 & 2.372 & 1.511 & 0.98 & 1.481 & 1.151 & 0.330 & 0.179 \\
\hline $5 \mathrm{H}-3,80.5$ & 34.71 & 2.376 & 1.511 & 0.99 & 1.496 & 1.136 & 0.360 & \\
\hline $5 \mathrm{H}-3,86.5$ & 34.77 & 2.380 & 1.511 & 0.96 & 1.451 & 1.099 & 0.352 & \\
\hline $5 \mathrm{H}-3,89.5$ & 34.80 & 2.382 & 1.511 & 1.01 & 1.526 & 1.207 & 0.319 & \\
\hline $5 \mathrm{H}-3,95.5$ & 34.86 & 2.386 & 1.511 & 0.94 & 1.420 & 1.144 & 0.276 & \\
\hline $5 \mathrm{H}-3,101.6$ & 34.92 & 2.390 & 1.511 & 0.98 & 1.481 & 1.226 & 0.255 & \\
\hline $5 \mathrm{H}-3,104.5$ & 34.94 & 2.391 & 1.511 & 0.99 & 1.496 & 1.277 & 0.219 & 0.148 \\
\hline $5 \mathrm{H}-3,110.5$ & 35.01 & 2.395 & 1.511 & 0.94 & 1.420 & 1.203 & 0.217 & \\
\hline $5 \mathrm{H}-3,116.7$ & 35.07 & 2.399 & 1.511 & 1.05 & 1.587 & 1.346 & 0.241 & \\
\hline $5 \mathrm{H}-3,119.6$ & 35.10 & 2.401 & 1.511 & 1.07 & 1.617 & 1.316 & 0.300 & \\
\hline $5 \mathrm{H}-3,125.5$ & 35.16 & 2.405 & 1.511 & 1.01 & 1.526 & 1.204 & 0.322 & \\
\hline $5 \mathrm{H}-3,131.5$ & 35.22 & 2.409 & 1.511 & 0.96 & 1.451 & 0.940 & 0.511 & 0.235 \\
\hline $5 \mathrm{H}-3,134.5$ & 35.25 & 2.411 & 1.511 & 1.03 & 1.556 & 1.170 & 0.386 & \\
\hline $5 \mathrm{H}-3,140.7$ & 35.31 & 2.415 & 1.511 & 0.98 & 1.481 & 1.072 & 0.408 & \\
\hline $5 \mathrm{H}-3,146.5$ & 35.37 & 2.419 & 1.511 & 1.07 & 1.617 & 1.091 & 0.526 & 0.237 \\
\hline $5 \mathrm{H}-3,149.5$ & 35.40 & 2.421 & 1.511 & 1.09 & 1.647 & 1.014 & 0.633 & \\
\hline $5 \mathrm{H}-4,5.5$ & 35.45 & 2.425 & 1.511 & 1.01 & 1.526 & 1.181 & 0.345 & \\
\hline $5 \mathrm{H}-4,11.5$ & 35.51 & 2.429 & 1.511 & 0.96 & 1.451 & 1.041 & 0.410 & 0.257 \\
\hline $5 \mathrm{H}-4,14.5$ & 35.54 & 2.431 & 1.511 & 0.98 & 1.481 & 1.194 & 0.287 & \\
\hline $5 \mathrm{H}-4,20.5$ & 35.60 & 2.435 & 1.511 & 1.01 & 1.526 & 1.265 & 0.261 & \\
\hline $5 \mathrm{H}-4,26.5$ & 35.66 & 2.438 & 1.511 & 0.96 & 1.451 & 1.162 & 0.288 & 0.169 \\
\hline $5 \mathrm{H}-4,29.5$ & 35.69 & 2.441 & 1.511 & 0.99 & 1.496 & 1.119 & 0.377 & \\
\hline $5 \mathrm{H}-4,35.5$ & 35.75 & 2.444 & 1.511 & 0.90 & 1.360 & 0.989 & 0.371 & \\
\hline $5 \mathrm{H}-4,41.5$ & 35.81 & 2.448 & 1.511 & 0.94 & 1.420 & 0.988 & 0.433 & \\
\hline $5 \mathrm{H}-4,44.5$ & 35.84 & 2.450 & 1.511 & 0.84 & 1.269 & 0.777 & 0.493 & \\
\hline $5 \mathrm{H}-4,50.5$ & 35.90 & 2.454 & 1.511 & 0.85 & 1.284 & 0.753 & 0.531 & 0.268 \\
\hline $5 \mathrm{H}-4,56.5$ & 35.96 & 2.458 & 1.511 & 0.74 & 1.118 & 0.708 & 0.410 & \\
\hline $5 \mathrm{H}-4,59.5$ & 35.99 & 2.460 & 1.511 & 0.88 & 1.330 & 0.940 & 0.389 & \\
\hline $5 \mathrm{H}-4,65.5$ & 36.05 & 2.464 & 1.511 & 0.84 & 1.269 & 1.058 & 0.211 & \\
\hline $5 \mathrm{H}-4,71.6$ & 36.11 & 2.468 & 1.511 & 0.93 & 1.405 & 1.177 & 0.228 & \\
\hline $5 \mathrm{H}-4,74.5$ & 36.14 & 2.470 & 1.511 & 0.98 & 1.481 & 1.232 & 0.249 & 0.163 \\
\hline $5 \mathrm{H}-4,80.6$ & 36.20 & 2.474 & 1.511 & 0.93 & 1.405 & 1.145 & 0.260 & \\
\hline $5 \mathrm{H}-4,86.5$ & 36.26 & 2.478 & 1.511 & 0.81 & 1.224 & 0.999 & 0.224 & \\
\hline $5 \mathrm{H}-4,89.5$ & 36.29 & 2.480 & 1.511 & 0.91 & 1.375 & 1.103 & 0.272 & \\
\hline $5 \mathrm{H}-4,95.5$ & 36.35 & 2.484 & 1.511 & 0.88 & 1.330 & 1.066 & 0.264 & \\
\hline $5 \mathrm{H}-4,98.6$ & 36.38 & 2.486 & 1.511 & 0.94 & 1.420 & 1.121 & 0.300 & \\
\hline $5 \mathrm{H}-4,107.5$ & 36.47 & 2.492 & 1.511 & 0.87 & 1.315 & 0.868 & 0.446 & 0.223 \\
\hline $5 \mathrm{H}-4,110.5$ & 36.50 & 2.494 & 1.511 & 0.91 & 1.375 & 0.980 & 0.395 & \\
\hline $5 \mathrm{H}-4,116.5$ & 36.56 & 2.498 & 1.511 & 0.93 & 1.405 & 0.995 & 0.410 & \\
\hline $5 \mathrm{H}-4,119.5$ & 36.59 & 2.500 & 1.511 & 0.93 & 1.405 & 1.059 & 0.346 & \\
\hline $5 \mathrm{H}-4,125.6$ & 36.65 & 2.504 & 1.511 & 0.90 & 1.360 & 0.962 & 0.398 & \\
\hline $5 \mathrm{H}-4,131.5$ & 36.71 & 2.508 & 1.511 & 1.03 & 1.556 & 1.061 & 0.496 & \\
\hline $5 \mathrm{H}-4,134.5$ & 36.74 & 2.510 & 1.511 & 0.87 & 1.315 & 0.796 & 0.518 & \\
\hline $5 \mathrm{H}-4,140.5$ & 36.80 & 2.514 & 1.511 & 0.91 & 1.375 & 0.595 & 0.780 & 0.399 \\
\hline $5 \mathrm{H}-4,146.5$ & 36.86 & 2.518 & 1.511 & 0.88 & 1.330 & 0.655 & 0.675 & \\
\hline $5 \mathrm{H}-4,149.5$ & 36.89 & 2.520 & 1.511 & 0.94 & 1.420 & 1.175 & 0.245 & \\
\hline $5 \mathrm{H}-5,5.5$ & 36.96 & 2.525 & 1.511 & 0.98 & 1.481 & 1.261 & 0.220 & \\
\hline $5 \mathrm{H}-5,11.5$ & 37.02 & 2.529 & 1.511 & 1.05 & 1.587 & 1.366 & 0.221 & \\
\hline $5 \mathrm{H}-5,14.5$ & 37.05 & 2.530 & 1.511 & 1.03 & 1.556 & 1.324 & 0.232 & 0.142 \\
\hline $5 \mathrm{H}-5,20.5$ & 37.11 & 2.534 & 1.511 & 1.03 & 1.556 & 1.304 & 0.252 & \\
\hline $5 \mathrm{H}-5,26.5$ & 37.17 & 2.539 & 1.511 & 0.98 & 1.481 & 1.166 & 0.314 & \\
\hline $5 \mathrm{H}-5,29.5$ & 37.19 & 2.540 & 1.511 & 1.01 & 1.526 & 1.220 & 0.307 & \\
\hline $5 \mathrm{H}-5,35.5$ & 37.26 & 2.544 & 1.511 & 0.99 & 1.496 & 1.159 & 0.337 & \\
\hline $5 \mathrm{H}-5,41.5$ & 37.32 & 2.548 & 1.511 & 0.99 & 1.496 & 1.197 & 0.299 & \\
\hline $5 \mathrm{H}-5,44.5$ & 37.35 & 2.550 & 1.511 & 1.07 & 1.617 & 1.297 & 0.320 & \\
\hline $5 \mathrm{H}-5,50.5$ & 37.41 & 2.554 & 1.511 & 0.99 & 1.496 & 1.103 & 0.393 & 0.230 \\
\hline $5 \mathrm{H}-5,56.5$ & 37.47 & 2.558 & 1.511 & 0.96 & 1.451 & 0.976 & 0.475 & \\
\hline $5 \mathrm{H}-5,59.5$ & 37.50 & 2.560 & 1.511 & 0.88 & 1.330 & 0.783 & 0.547 & \\
\hline $5 \mathrm{H}-5,62.5$ & 37.53 & 2.562 & 1.511 & 0.96 & 1.451 & 0.340 & 1.111 & 0.685 \\
\hline $5 \mathrm{H}-5,68.5$ & 37.59 & 2.566 & 1.511 & 0.94 & 1.420 & 0.905 & 0.515 & \\
\hline $5 \mathrm{H}-5,74.5$ & 37.65 & 2.570 & 1.511 & 0.98 & 1.481 & 1.160 & 0.320 & 0.128 \\
\hline $5 \mathrm{H}-5,80.6$ & 37.71 & 2.574 & 1.511 & 0.99 & 1.496 & 1.202 & 0.294 & \\
\hline $5 \mathrm{H}-5,86.5$ & 37.77 & 2.578 & 1.511 & 1.03 & 1.556 & 1.293 & 0.263 & \\
\hline $5 \mathrm{H}-5,89.5$ & 37.80 & 2.580 & 1.511 & 1.11 & 1.677 & 1.439 & 0.239 & \\
\hline $5 \mathrm{H}-5,95.5$ & 37.86 & 2.584 & 1.511 & 1.05 & 1.587 & 1.346 & 0.240 & \\
\hline
\end{tabular}


APPENDIX C (continued).

\begin{tabular}{|c|c|c|c|c|c|c|c|c|c|c|}
\hline \multirow{2}{*}{$\begin{array}{l}\text { Core, section, } \\
\text { interval }(\mathrm{cm})\end{array}$} & \multirow{2}{*}{$\begin{array}{l}\text { Depth } \\
\text { (mbsf) }\end{array}$} & Age & & & MAR & CAR & NCAR & OMAR & TMAR & $\mathrm{TMAR}^{2}$ \\
\hline & & (Ma) & $(\mathrm{cm} / \mathrm{k} . \mathrm{y})$. & $\left(\mathrm{g} / \mathrm{cm}^{3}\right)$ & & & $m^{2} \times k \cdot y$ & & & $\mathrm{mg}\left(\mathrm{cm}^{2} \times \mathrm{k} . \mathrm{y} .\right)^{-1}$ \\
\hline $5 \mathrm{H}-5,101.5$ & 37.92 & 2.588 & 1.511 & 1.07 & 1.617 & 1.336 & 0.280 & & & \\
\hline $5 \mathrm{H}-5,104.5$ & 37.94 & 2.589 & 1.511 & 1.20 & 1.813 & 1.458 & 0.355 & & & \\
\hline $5 \mathrm{H}-5,110.5$ & 38.01 & 2.594 & 1.511 & 0.98 & 1.481 & 1.083 & 0.398 & 0.215 & 0.182 & 182 \\
\hline $5 \mathrm{H}-5,116.5$ & 38.07 & 2.598 & 1.511 & 0.96 & 1.451 & 0.974 & 0.477 & & & \\
\hline $5 \mathrm{H}-5,119.5$ & 38.10 & 2.600 & 1.531 & 0.94 & 1.439 & 0.645 & 0.794 & 0.275 & 0.519 & 519 \\
\hline $5 \mathrm{H}-5,125.6$ & 38.16 & 2.604 & 1.531 & 1.01 & 1.546 & 1.153 & 0.394 & & & \\
\hline $5 \mathrm{H}-5,131.5$ & 38.22 & 2.608 & 1.531 & 0.93 & 1.424 & 1.061 & 0.363 & & & \\
\hline $5 \mathrm{H}-5,134.5$ & 38.25 & 2.610 & 1.531 & 0.91 & 1.393 & 0.999 & 0.394 & & & \\
\hline $5 \mathrm{H}-5,140.5$ & 38.31 & 2.614 & 1.531 & 1.01 & 1.546 & 1.104 & 0.442 & 0.308 & 0.134 & 134 \\
\hline $5 \mathrm{H}-5,146.5$ & 38.37 & 2.618 & 1.531 & 1.17 & 1.791 & 1.514 & 0.277 & & & \\
\hline $5 \mathrm{H}-5,149.5$ & 38.40 & 2.620 & 1.531 & 1.05 & 1.608 & 1.369 & 0.239 & & & \\
\hline $5 \mathrm{H}-6,5.5$ & 38.46 & 2.624 & 1.531 & 0.93 & 1.424 & 1.206 & 0.218 & 0.099 & 0.120 & 120 \\
\hline $5 \mathrm{H}-6,11.5$ & 38.52 & 2.627 & 1.531 & 1.15 & 1.761 & 1.435 & 0.326 & & & \\
\hline $5 \mathrm{H}-6,17.5$ & 38.58 & 2.631 & 1.531 & 0.98 & 1.500 & 1.149 & 0.352 & & & \\
\hline $5 \mathrm{H}-6,20.5$ & 38.61 & 2.633 & 1.531 & 1.11 & 1.699 & 1.302 & 0.397 & & & \\
\hline $5 \mathrm{H}-6,26.5$ & 38.67 & 2.637 & 1.531 & 1.01 & 1.546 & 1.066 & 0.480 & & & \\
\hline $5 \mathrm{H}-6,29.5$ & 38.69 & 2.638 & 1.531 & 0.96 & 1.470 & 0.964 & 0.506 & 0.185 & 0.321 & 321 \\
\hline $5 \mathrm{H}-6,35.5$ & 38.76 & 2.643 & 1.531 & 0.85 & 1.301 & 0.828 & 0.473 & & & \\
\hline $5 \mathrm{H}-6,41.5$ & 38.82 & 2.647 & 1.531 & 1.09 & 1.669 & 1.227 & 0.442 & & & \\
\hline $5 \mathrm{H}-6,44.5$ & 38.85 & 2.649 & 1.531 & 1.18 & 1.807 & 1.541 & 0.265 & & & \\
\hline $5 \mathrm{H}-6,50.5$ & 38.91 & 2.653 & 1.531 & 0.98 & 1.500 & 1.302 & 0.199 & & & \\
\hline $5 \mathrm{H}-6,56.5$ & 38.97 & 2.657 & 1.531 & 1.01 & 1.546 & 1.360 & 0.186 & 0.118 & 0.069 & 69 \\
\hline $5 \mathrm{H}-6,59.5$ & 39.00 & 2.659 & 1.531 & 1.07 & 1.638 & 1.400 & 0.238 & & & \\
\hline $5 \mathrm{H}-6,65.5$ & 39.06 & 2.663 & 1.531 & 1.03 & 1.577 & 1.320 & 0.257 & & & \\
\hline $5 \mathrm{H}-6,71.5$ & 39.12 & 2.667 & 1.531 & 1.05 & 1.608 & 1.298 & 0.309 & & & \\
\hline $5 \mathrm{H}-6,74.5$ & 39.15 & 2.669 & 1.531 & 1.03 & 1.577 & 1.285 & 0.292 & & & \\
\hline $5 \mathrm{H}-6,80.6$ & 39.21 & 2.672 & 1.531 & 1.01 & 1.546 & 1.310 & 0.236 & & & \\
\hline $5 \mathrm{H}-6,86.5$ & 39.27 & 2.676 & 1.531 & 1.13 & 1.730 & 1.512 & 0.218 & & & \\
\hline $5 \mathrm{H}-6,89.6$ & 39.30 & 2.678 & 1.531 & 1.07 & 1.638 & 1.408 & 0.230 & & & \\
\hline $5 \mathrm{H}-6,95.5$ & 39.36 & 2.682 & 1.531 & 1.09 & 1.669 & 1.429 & 0.239 & 0.164 & 0.075 & 75 \\
\hline $5 \mathrm{H}-6,101.5$ & 39.42 & 2.686 & 1.531 & 1.07 & 1.638 & 1.395 & 0.244 & & & \\
\hline $5 \mathrm{H}-6,107.5$ & 39.48 & 2.690 & 1.531 & 0.96 & 1.470 & 1.212 & 0.258 & & & \\
\hline $5 \mathrm{H}-6,110.6$ & 39.51 & 2.692 & 1.531 & 0.93 & 1.424 & 1.128 & 0.296 & & & \\
\hline $5 \mathrm{H}-6,116.5$ & 39.57 & 2.696 & 1.531 & 1.15 & 1.761 & 1.338 & 0.423 & & & \\
\hline $5 \mathrm{H}-6,122.7$ & 39.63 & 2.700 & 1.531 & 0.96 & 1.470 & 1.023 & 0.447 & & & \\
\hline $5 \mathrm{H}-6,125.5$ & 39.66 & 2.702 & 1.531 & 0.95 & 1.454 & 1.032 & 0.423 & 0.217 & 0.206 & 206 \\
\hline $5 \mathrm{H}-6,131.6$ & 39.72 & 2.706 & 1.531 & 0.93 & 1.424 & 1.049 & 0.375 & & & \\
\hline $5 \mathrm{H}-6,134.5$ & 39.75 & 2.708 & 1.531 & 0.88 & 1.347 & 0.985 & 0.363 & & & \\
\hline $5 \mathrm{H}-6,140.7$ & 39.81 & 2.712 & 1.531 & 0.96 & 1.470 & 1.166 & 0.304 & & & \\
\hline $5 \mathrm{H}-6,146.6$ & 39.87 & 2.716 & 1.531 & 0.91 & 1.393 & 1.137 & 0.256 & 0.149 & 0.106 & 106 \\
\hline $5 \mathrm{H}-7,2.5$ & 39.93 & 2.720 & 1.531 & 0.94 & 1.439 & 1.203 & 0.236 & & & \\
\hline $5 \mathrm{H}-7,5.5$ & 39.96 & 2.721 & 1.531 & 1.01 & 1.546 & 1.305 & 0.242 & & & \\
\hline $5 \mathrm{H}-7,11.5$ & 40.02 & 2.725 & 1.531 & 1.01 & 1.546 & 1.300 & 0.246 & & & \\
\hline $5 \mathrm{H}-7,14.5$ & 40.05 & 2.727 & 1.531 & 0.94 & 1.439 & 1.145 & 0.294 & & & \\
\hline $5 \mathrm{H}-7,20.5$ & 40.11 & 2.731 & 1.531 & 0.87 & 1.332 & 1.026 & 0.306 & 0.175 & 0.131 & 131 \\
\hline $5 \mathrm{H}-7,26.5$ & 40.17 & 2.735 & 1.531 & 1.04 & 1.592 & 1.177 & 0.416 & & & \\
\hline $5 \mathrm{H}-7,29.5$ & 40.19 & 2.737 & 1.531 & 0.94 & 1.439 & 0.989 & 0.450 & & & \\
\hline $5 \mathrm{H}-7,35.5$ & 40.26 & 2.741 & 1.531 & 0.84 & 1.286 & 0.789 & 0.497 & & & \\
\hline $5 \mathrm{H}-7,41.5$ & 40.32 & 2.745 & 1.531 & 0.84 & 1.286 & 0.642 & 0.644 & 0.257 & 0.387 & 387 \\
\hline $5 \mathrm{H}-7,44.5$ & 40.35 & 2.747 & 1.531 & 0.83 & 1.271 & 0.670 & 0.601 & & & \\
\hline $5 \mathrm{H}-7,50.5$ & 40.41 & 2.751 & 1.531 & 0.94 & 1.439 & 0.965 & 0.475 & & & \\
\hline $6 \mathrm{H}-1,2.5$ & 40.43 & 2.752 & 1.531 & 1.15 & 1.761 & 1.416 & 0.344 & & & \\
\hline $6 \mathrm{H}-1,5.5$ & 40.46 & 2.754 & 1.531 & 0.96 & 1.470 & 1.176 & 0.294 & & & \\
\hline $6 \mathrm{H}-1,11.5$ & 40.52 & 2.758 & 1.531 & 0.98 & 1.500 & 1.221 & 0.280 & & & \\
\hline $6 \mathrm{H}-1,14.5$ & 40.55 & 2.760 & 1.983 & 0.91 & 1.805 & 1.468 & 0.337 & & & \\
\hline $6 \mathrm{H}-1,20.5$ & 40.61 & 2.763 & 1.983 & 0.93 & 1.844 & 1.292 & 0.552 & & & \\
\hline $6 \mathrm{H}-1,26.5$ & 40.67 & 2.766 & 1.983 & 0.98 & 1.943 & 1.158 & 0.785 & & & \\
\hline $6 \mathrm{H}-1,29.5$ & 40.69 & 2.767 & 1.983 & 1.05 & 2.082 & 1.054 & 1.029 & & & \\
\hline $6 \mathrm{H}-1,35.5$ & 40.76 & 2.771 & 1.983 & 1.01 & 2.003 & 1.347 & 0.656 & & & \\
\hline $6 \mathrm{H}-1,41.5$ & 40.82 & 2.774 & 1.983 & 1.13 & 2.241 & 1.454 & 0.787 & & & \\
\hline $6 \mathrm{H}-1,44.5$ & 40.85 & 2.775 & 1.983 & 1.11 & 2.201 & 1.866 & 0.335 & & & \\
\hline $6 \mathrm{H}-1,50.5$ & 40.91 & 2.778 & 1.983 & 1.13 & 2.241 & 1.879 & 0.362 & & & \\
\hline $6 \mathrm{H}-1,53.5$ & 40.94 & 2.780 & 1.983 & 1.05 & 2.082 & 1.615 & 0.467 & & & \\
\hline $6 \mathrm{H}-1,59.5$ & 41.00 & 2.783 & 1.983 & 1.09 & 2.161 & 1.852 & 0.309 & & & \\
\hline $6 \mathrm{H}-1,65.5$ & 41.06 & 2.786 & 1.983 & 1.11 & 2.201 & 1.863 & 0.338 & & & \\
\hline $6 \mathrm{H}-1,71.5$ & 41.12 & 2.789 & 1.983 & 1.09 & 2.161 & 1.884 & 0.277 & & & \\
\hline $6 \mathrm{H}-1,74.5$ & 41.15 & 2.790 & 1.983 & 1.07 & 2.122 & 1.797 & 0.325 & & & \\
\hline $6 \mathrm{H}-1,80.6$ & 41.21 & 2.793 & 1.983 & 1.01 & 2.003 & 1.679 & 0.324 & & & \\
\hline $6 \mathrm{H}-1,86.5$ & 41.27 & 2.796 & 1.983 & 1.11 & 2.201 & 1.836 & 0.365 & & & \\
\hline $6 \mathrm{H}-1,89.6$ & 41.30 & 2.798 & 1.983 & 1.07 & 2.122 & 1.655 & 0.467 & & & \\
\hline $6 \mathrm{H}-1,95.5$ & 41.36 & 2.801 & 1.983 & 0.96 & 1.904 & 1.517 & 0.387 & & & \\
\hline $6 \mathrm{H}-1,101.5$ & 41.42 & 2.804 & 1.983 & 1.03 & 2.042 & 1.552 & 0.491 & & & \\
\hline $6 \mathrm{H}-1,104.5$ & 41.44 & 2.805 & 1.983 & 1.09 & 2.161 & 1.555 & 0.607 & & & \\
\hline $6 \mathrm{H}-1,110.6$ & 41.51 & 2.808 & 1.983 & 1.07 & 2.122 & 1.573 & 0.549 & & & \\
\hline $6 \mathrm{H}-1,116.5$ & 41.57 & 2.811 & 1.983 & 1.15 & 2.280 & 1.644 & 0.637 & & & \\
\hline $6 \mathrm{H}-1,119.5$ & 41.60 & 2.813 & 1.983 & 1.09 & 2.161 & 1.580 & 0.581 & & & \\
\hline $6 \mathrm{H}-1,125.5$ & 41.66 & 2.816 & 1.983 & 1.07 & 2.122 & 1.659 & 0.463 & & & \\
\hline $6 \mathrm{H}-1,131.5$ & 41.72 & 2.819 & 1.983 & 1.20 & 2.380 & 1.861 & 0.519 & & & \\
\hline $6 \mathrm{H}-1,134.5$ & 41.75 & 2.820 & 1.983 & 1.05 & 2.082 & 1.793 & 0.289 & & & \\
\hline $6 \mathrm{H}-1,140.5$ & 41.81 & 2.823 & 1.983 & 1.07 & 2.122 & 1.796 & 0.325 & & & \\
\hline $6 \mathrm{H}-1,146.5$ & 41.87 & 2.827 & 1.983 & 1.05 & 2.082 & 1.768 & 0.314 & & & \\
\hline $6 \mathrm{H}-1,149.6$ & 41.90 & 2.828 & 1.983 & 0.94 & 1.864 & 1.567 & 0.297 & & & \\
\hline
\end{tabular}

Notes: Depth $(\mathrm{mbs} f)=$ sub-bottom depth in meters below seafloor; age $(\mathrm{Ma})=$ millions of years ago: $\mathrm{LSR}=$ linear sedimentation rate $(\mathrm{cm}$ per thousand years); $\mathrm{DBD}=\mathrm{dry}$ bulk density $\left(\mathrm{g} / \mathrm{cm}^{3}\right) ; \mathrm{MAR}=$ mass (bulk) accumulation rate (grams of sediment per square $\mathrm{cm}$ per thousand years; same units for other rates); CAR = carbonate accumulation rate; NCAR = noncarbonate accumulation rate; $\mathrm{OMAR}=$ noncarbonate minus eolian accumulation rate; $\mathrm{TMAR}^{1}=$ terrigenous accumulation rate (lithogenic material $\left.<63 \mu \mathrm{m}\right)$ in units of $\mathrm{g}\left(\mathrm{cm} \mathrm{m}^{2}\right.$ $\times$ k.y. $)^{-1} ; \mathrm{TMAR}^{2}=$ terrigenous accumulation rate in units of $\mathrm{mg}\left(\mathrm{cm}^{2} \times \mathrm{k} . \mathrm{y} .\right)^{-1}$. The carbonate and noncarbonate weight percentages that are used to calculate accumulation rates are given in Rack et al. (1993). 